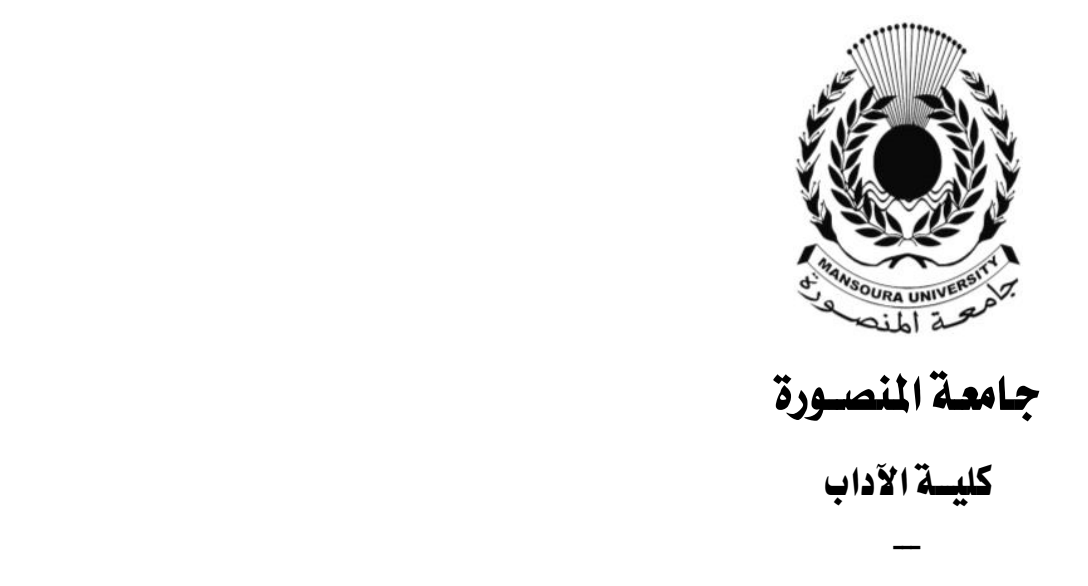

\title{
الدلالات المعرفية في شعر المعري: أنموذج اللزوهيات
}

\author{
إعـــ/د

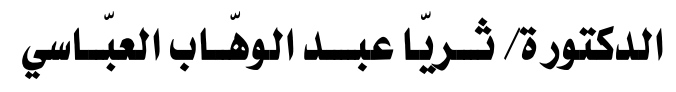 \\ أستاذ الأدب المقارن بجامعة الملك عبد العزيز \\ كلية الآداب والعلوم الإنسانية \\ قسم اللغة العربية
}

مجـلة كلـــية الآداب - جامعــة المنصــورة

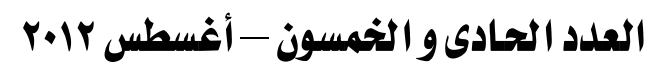




\section{الدلالات المعرفية}

\section{في شعر المعري: أنموذج اللزوميات}

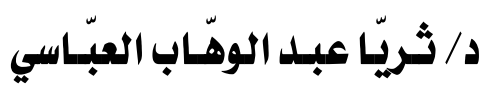

\section{مقدمة البحث}

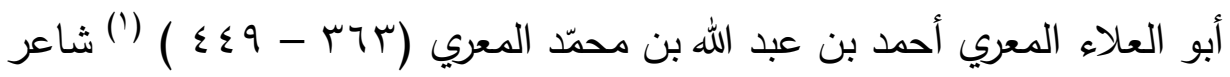

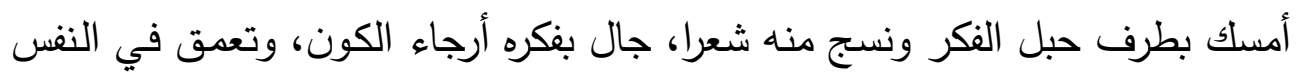

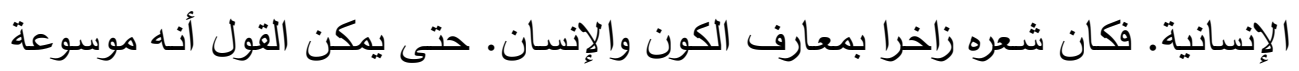

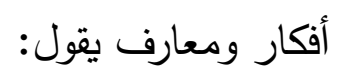
منه ينط بالثريا ذلك الطَّف الفكر حبل متى يُمسك على طرف شينًا و منه بنو الأيام تغترف والعقل كالبحر ما غيضت غواربه

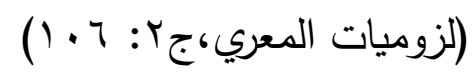

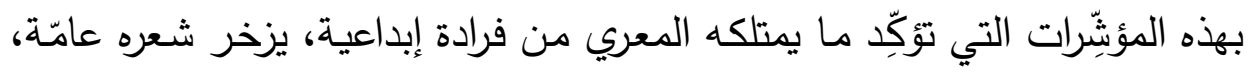

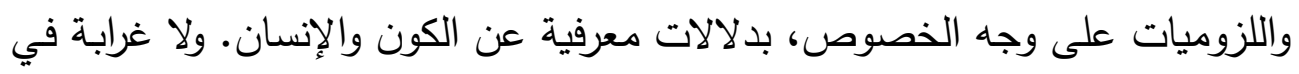
ذلك فقد "ظل حياته عاكفا على درس العلوم الطبيعية، والإلهية، والخلقية درسَا علميَّا

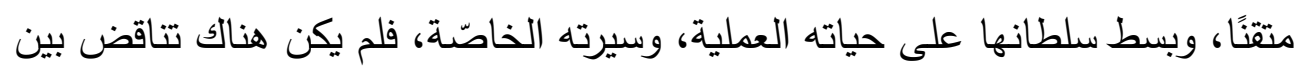

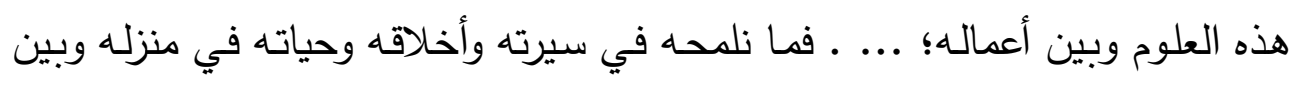

ا أنظر في ترجمته المراجع التالية: وفيات الأعيان وأنباء أبناء الزمان لابن خلِّكان، بغية الوعاة

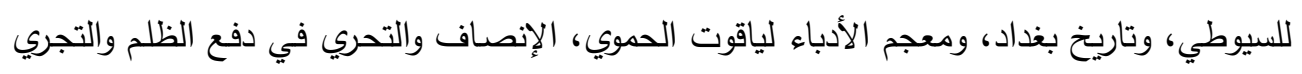
عن أبي العلاء المعري.لابن العديم الحلبي. 
الناس ومن درسـه للفلسفة في إنطاكية وطرابلس والثـام وبغداد، يدل على أنـه كان

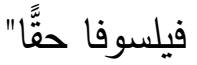

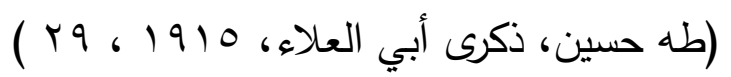

وإذا كانت الفلسفة في أبسط مفهوم لها، تعني البحث عن المعرفة، و الفيلسوف

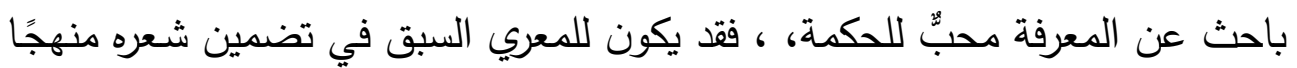

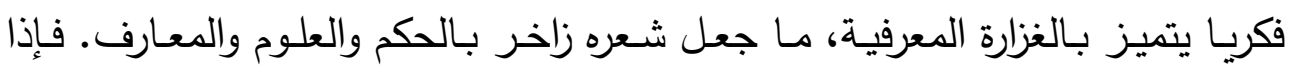

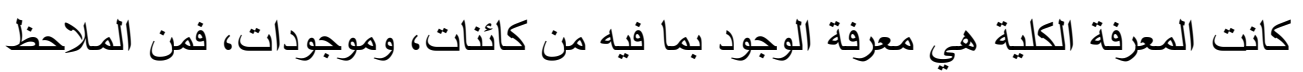

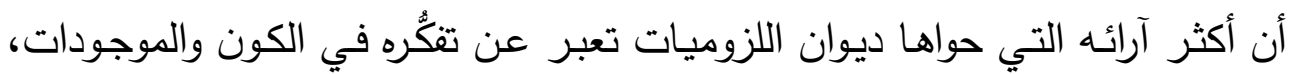

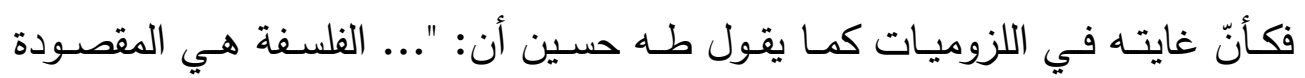
بتأليف الكتاب بالرغم من التأثير الظّاهر للعلوم ... الأخرى".(طه حسين ، ذكرى أنه أبي

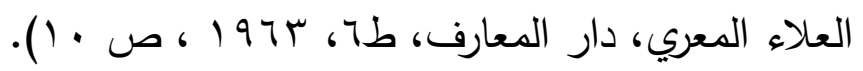

إن قارئ شعر المعري عامّة واللزوميات على وجه الخصوص يدرك أنه يقرأ فكرا ورؤى تأملية ذات صبغة قد تبدو في مضمونها أنها تحمل بعدا فلسفيا وأن كاتبها مفكرا أو كما يراه بعض النقاد فيلسوفا. لكن في حقيقته، إنما هو شاعر ربط شياعريته

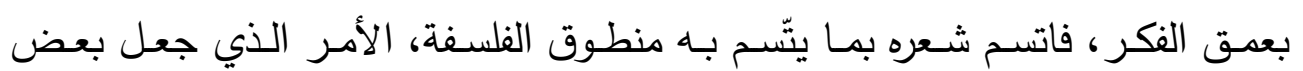

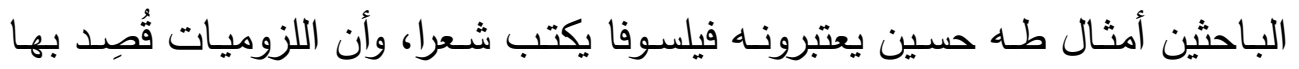
الفلسفة.

من هذا المنظور ، الدراسـة التي بـين أيدينا تسلِّط الضـوه على شـعر المعري

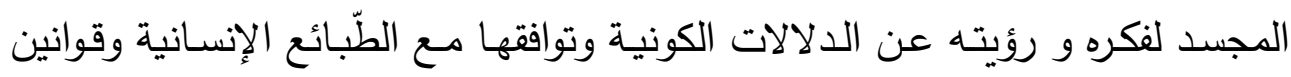

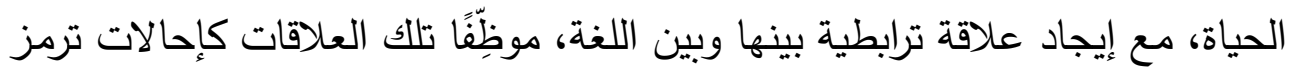

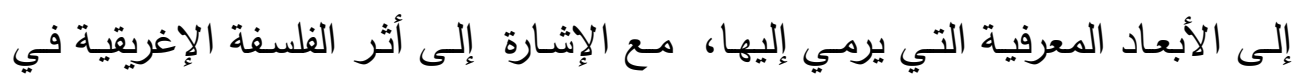

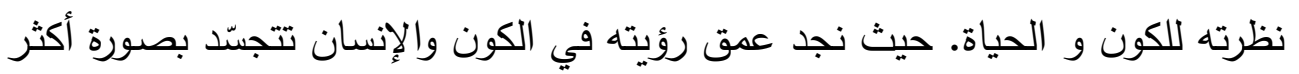




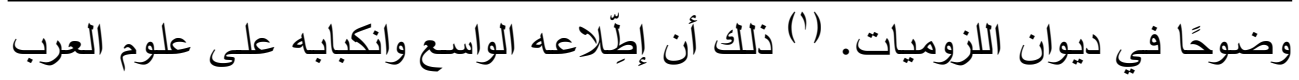

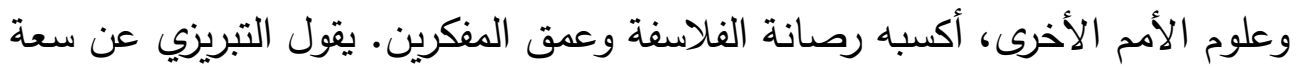

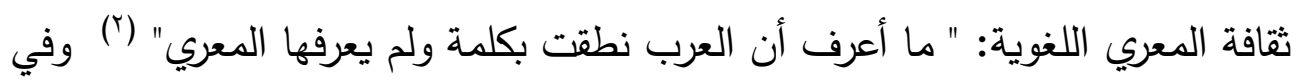

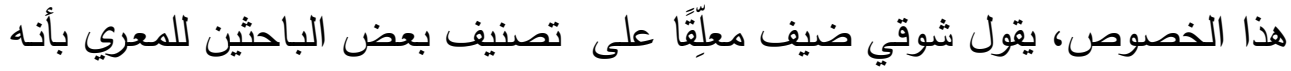

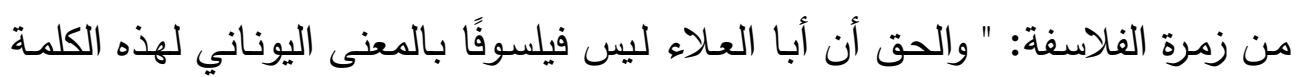

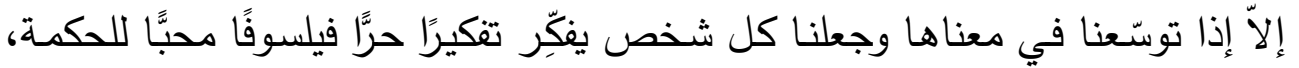

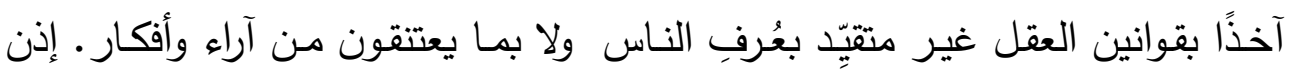

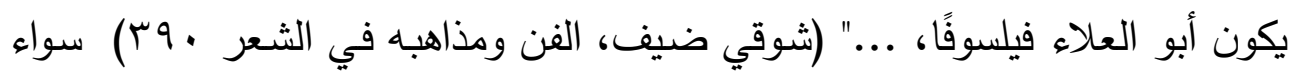

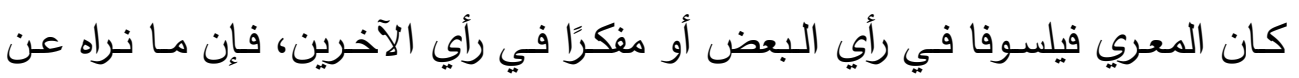

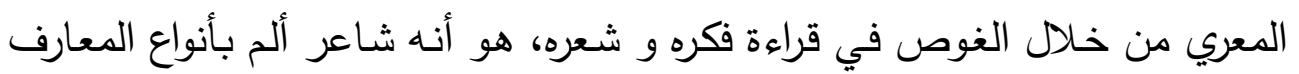

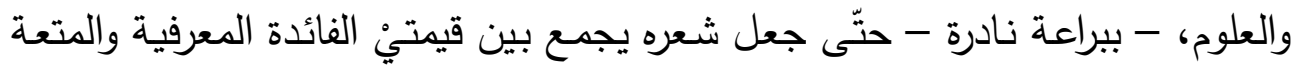

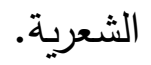

ا يرى بعض الدارسين أن اللزوميات "ليست شعرًا بالمعنى المتعارف، أي ممّا تدخل العاطفة،

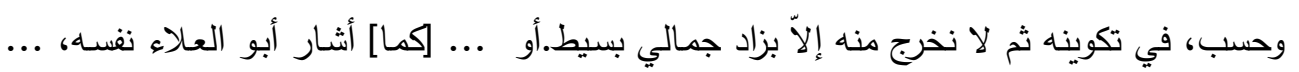

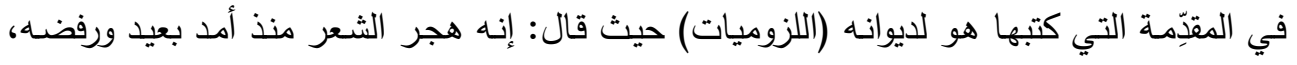

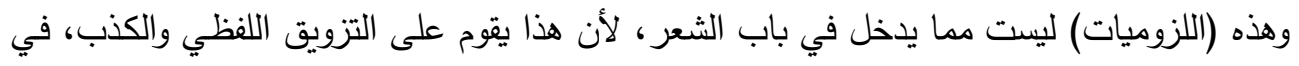

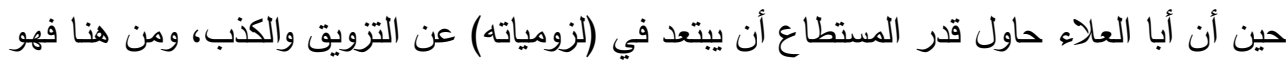

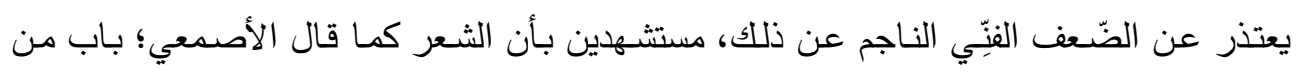

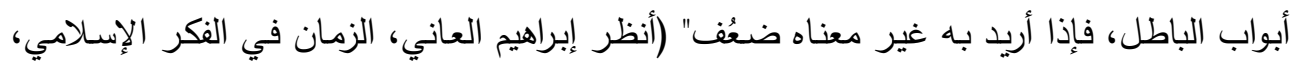

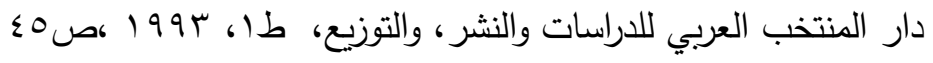
r أنظر شروح سقط الزند، للتبريزي والبطليوسي والخوارزمي، تحقيق مصطفى السقا وعبد السلام

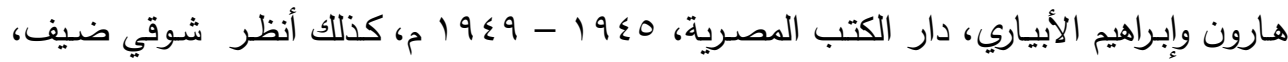

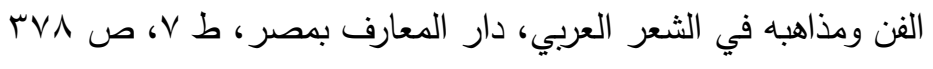


المنهجيـة التي تقتضيها طبيعة هذه الدراسـة؛ هي منهجية تجهع بين الاستـلال

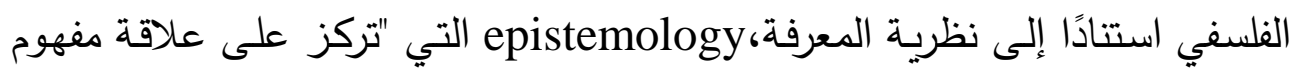

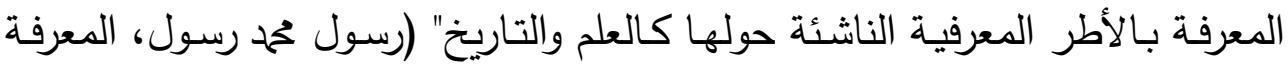

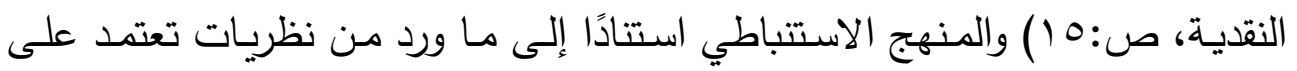
العلاقة الترابطية بين مختلف العلوم والمعارف، و استثمارهما في قراءة المضـامين

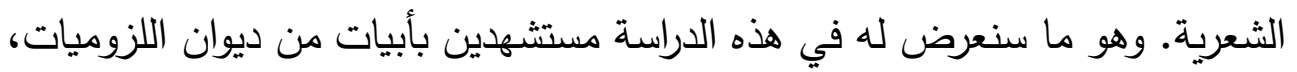

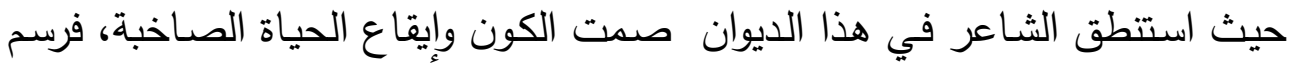
أحرفا انصهرت فيها المعرفة بالشعر، والعقل بالخيال، فتولد شعرا تفاعلت فيه الأفكار

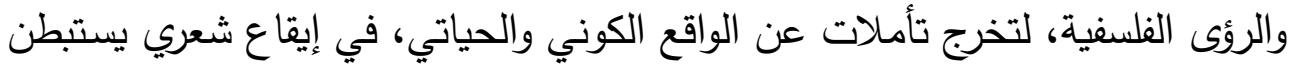

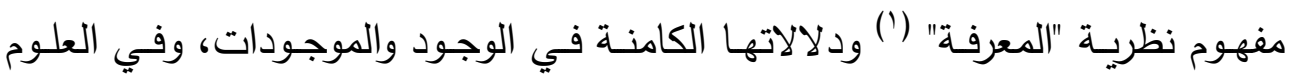

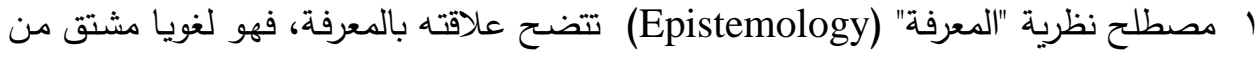

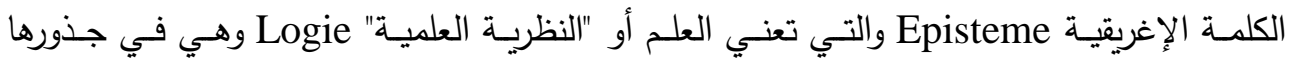

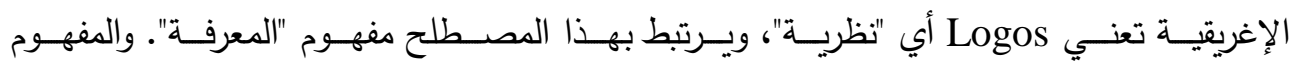
الإبستمولوجي (Epistemology) يشير إلى العلاقة الوثيقة بين أوجه العلوم والفنون والآداب، وإذا

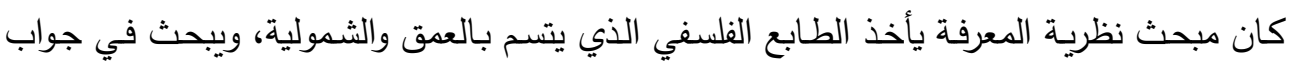

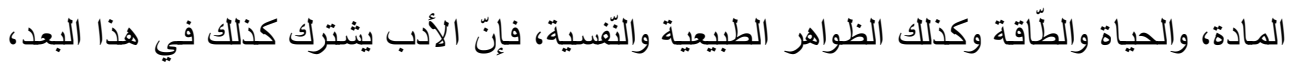

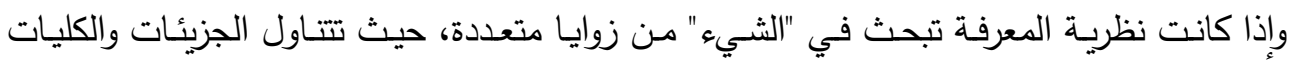

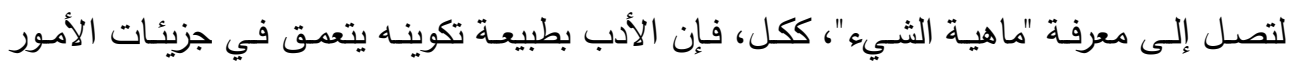

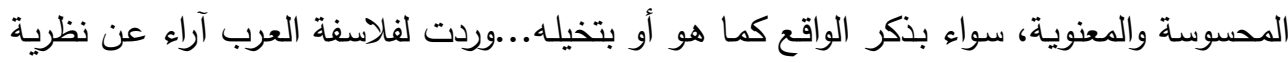

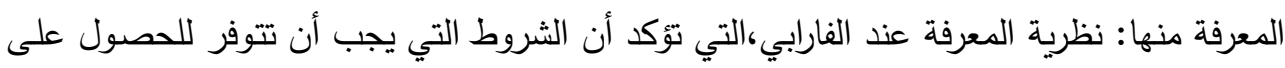

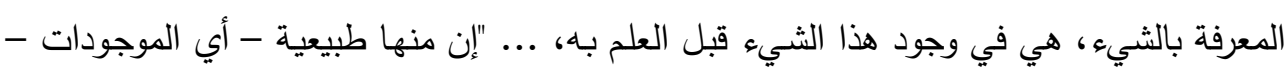

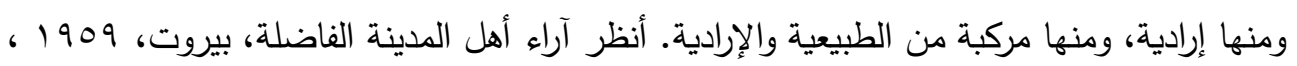

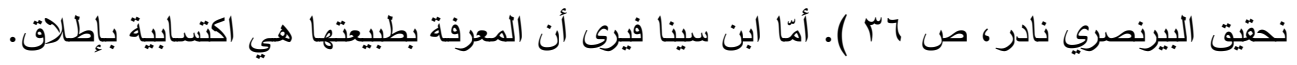

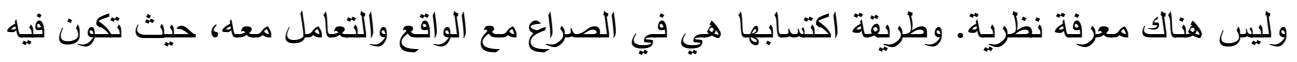

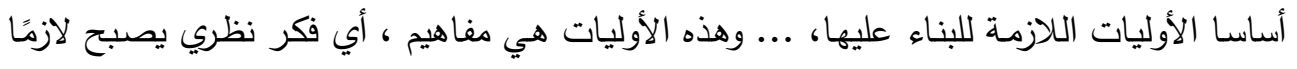




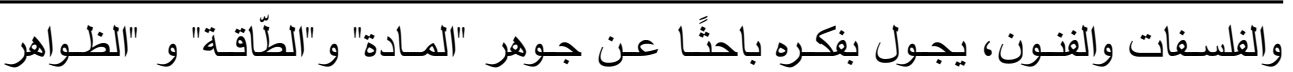

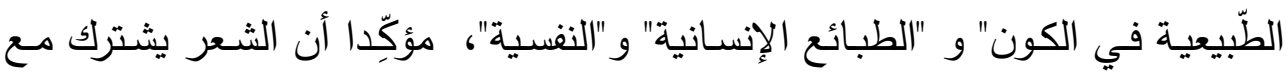
المعرفة في البحث عن ماهية الثيء و ترابطه بالآخر من حيث نوعية العلاقة، سواء

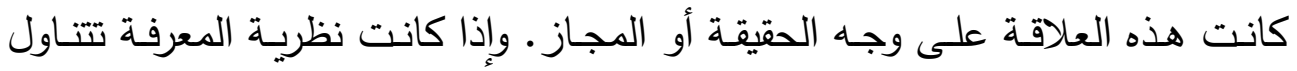

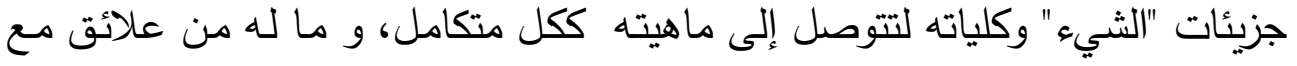

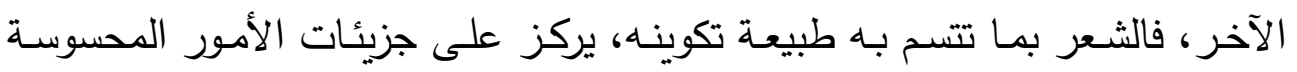

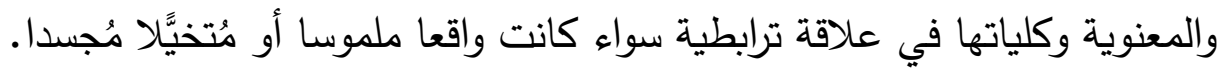
رؤيـة العرب عن الأدب عامّة والثـعر خاصّة، رؤيـة تُؤكِّد أن الأدب بفرعيه؛ الثعر والنثر يشبع طبيعة الإنسان التي تميل إلى البحث مصادر تؤمن لـه طرائق

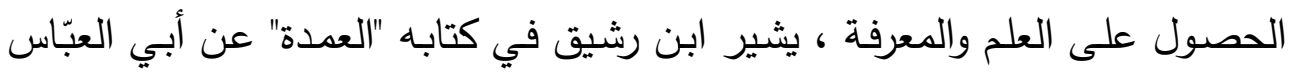

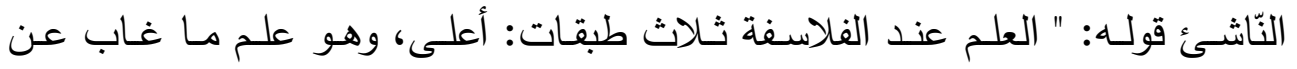

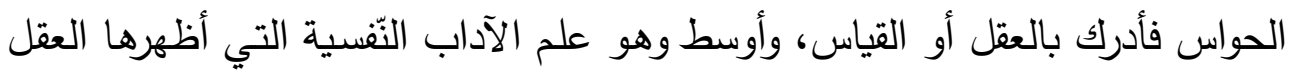

لإرشاد الفكر العملي، ... وهذه العملية تتبتها وتؤكِدِ صحّتها جميع العمليات التي يحصل بموجبها الإنسان على المعرفة. (أنظر كتاب )ابن خلدون وتفوق الفكر العربي على الفكر اليوناني باكتشاف

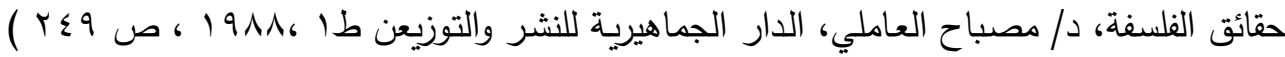
هناك فرق بين دلالة نظرية المعرفة (Theory of Knowledge) ونظرية المعرفة الإبستمولوجيا إذ بينما يحدث التركيز في الأولى على دراسـة المعرفة في أصلها، وتكوينها (Epistemilogy)

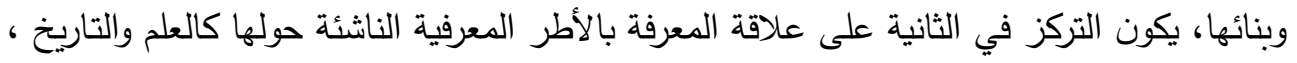

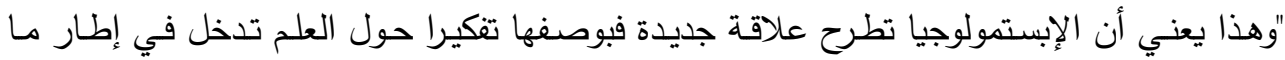

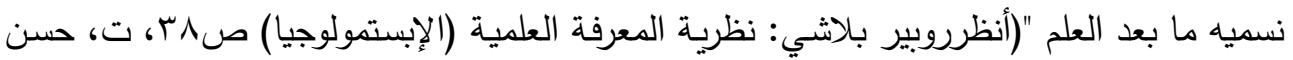
عبد الحميد، مطبوعات جامعة الكويت، 911 ( ) لذللك اعتبرها بعض النقاد أنها "تفكير النقدي حول كل العلوم والمعارف والفلسفات والفنون في نشاتها وتطورها والعلاقات المتداخلة بين نظريات وقضايا

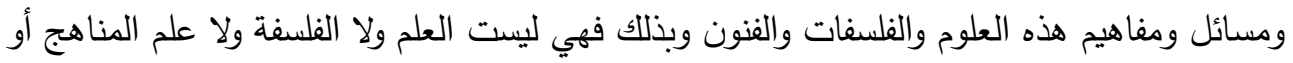

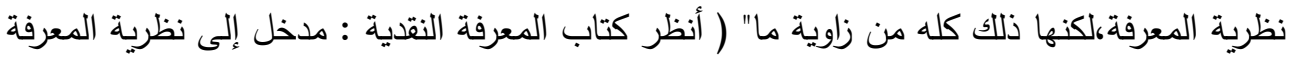

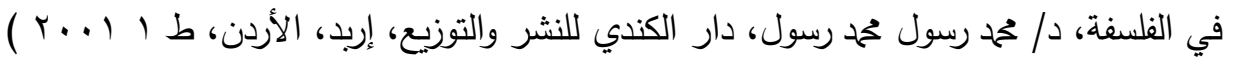


من الأثياء الطّبيعية كالأعداد والمساحات وصناعة التّجيم وصناعة اللُّحون، وأسفل، وهو العلم بالأشياء الجزئية والأشخاص الجسمية، فوجب - إذا كانت العلوم أفضلها ما لم تشـارك فيه الجسوم - أن يكون أفضل الصناعات مـا لم تشـارك فيه الآلات، وإذا إلاء كانت اللحون عند الفلاسفة أعظم أركان العمل الذي هو أحد قسمي الفلسفة وجدنا

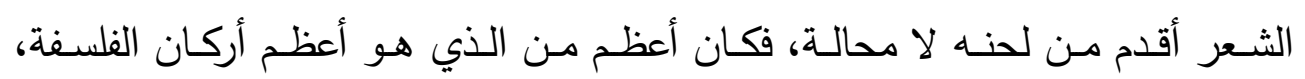

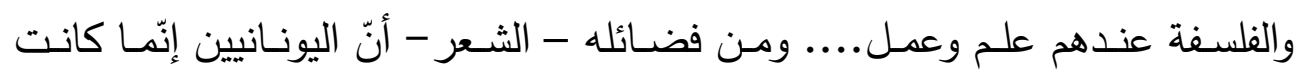

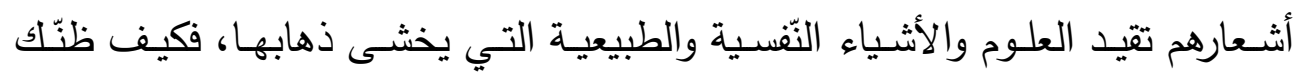
بالعرب الذي هو فخرهـا وفسطاسـها المستقيم". (ابن رشيق القيرواني، كتاب العمدة،

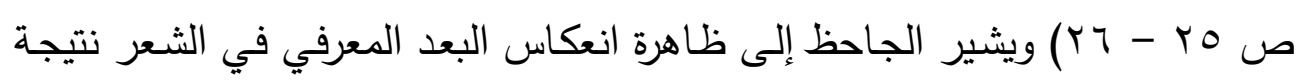
تأثر العرب بالفكر اليونـاني: " إنّا وجدنا الفلاسفة المتقدمين في الحكمـة، ذكروا أن أصسول الأدب التـي يتفـرّع منهـا العلم لذوي الألبـاب أربعـة: فمنهـا النجـوم وأبراجها وحسابها، ومنها الهندسة وما اتّصل بها من المساحة والوزن والتّّدير ، ومنها الكيمياء والطب وما يتشعب من ذلك، ومنها اللحون ومعرفة أجزائها ومخارجها وأوزانها."

$$
\text { (أحمد حسن الزيات، محاضرات ومقالات في الأدب العربي، ص • ( ) }
$$

هذه الرؤيسة انعكست في شـر المعري بصـورة واضـحة، فهو شـاعر يتوق إلى معرفة الكون وما به من ظواهر، فيرسم حركتها وسكونها؛ وما ينتج عنها من أحداث

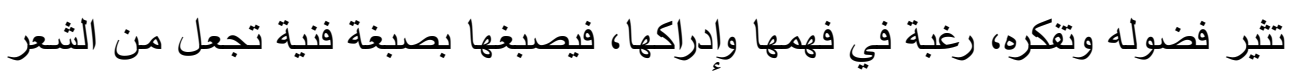
مصدر معرفة، إضـافة إلى كونسه مصدر إمتاع. فالمعري شـاعر مفكر عـاش في عصر انفتاح الفكر العربي، والتوسع العلمي، هدته بصيرته إلى البحث عن المعرفة الكامنة في الكون والحياة والإنسان، حتّى أصبح هذا الأمر هدفا يسعى لتحقيقه. فكان كثير الترحال باحثا عن العلوم والمعارف، يقول القفطي عن شغف المعري بالمعرفة: " ولمّا كبر ووصل إلى سن الطلب أخذ العربية عن قوم من بلدة كبني كوثر و من يجري مجراهم من أصحاب ابن خالويه وطبقته، وقيَّد اللغة عن أصحاب ابن خالويه 


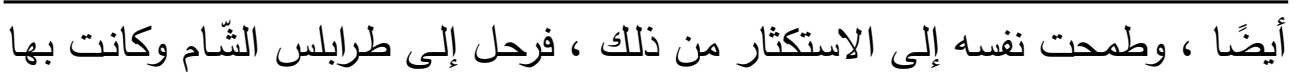

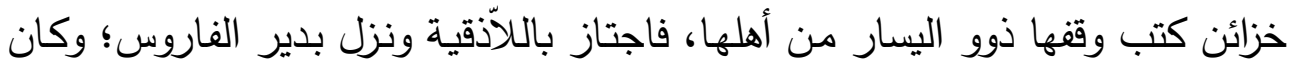
بها راهب يشدو شينًا من علوم الأوائل، فسمع منها أبو العلاء كلاهمًا من أوائل أقوال

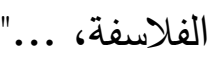

( القفطي، تعريف القدماء بأبي العلاء، ص . r، كذللك أنظر شوقي ضيف،

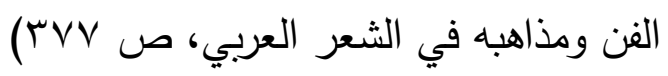

ومما يؤكد أيضًا غزارة علم المعري وانكبابه على العلوم التي كانت سائدة في عصره، قول ياقوت الحموي في وصفه لسعة علم المعري أنه كان: "وافر العلم، غاية

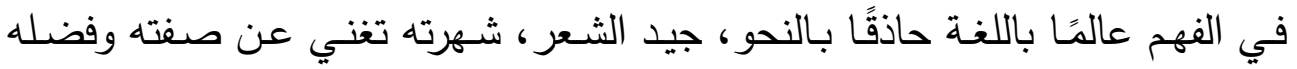

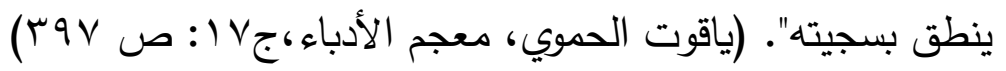
وفيما روي عنه أيضًا من كتّاب العصر الحديث، ما ورد عن شوقي ضيف: "أنه

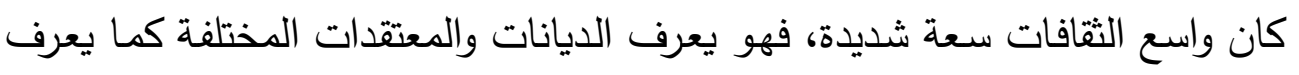
الفلسفة والتتجيم والتاريخ والتصوف، وما يطوي في ذلك من ثقافات يونانية وفارسية فئية

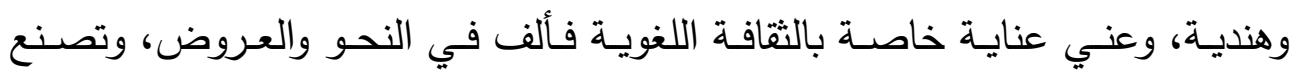

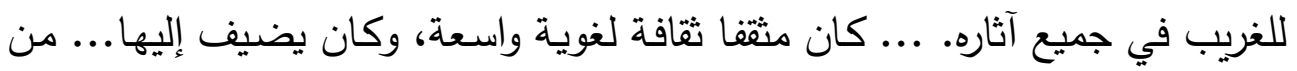
ثقافاته الكثيرة وخاصّة ما اتصل بالثقافة الفنية من الثعر، إذ كان يُعنى عناية شديدة

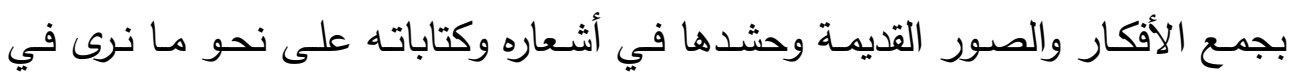

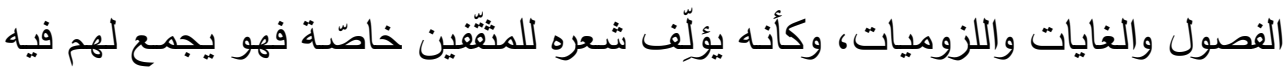

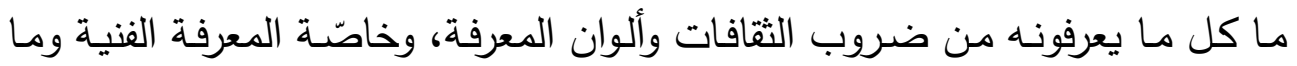

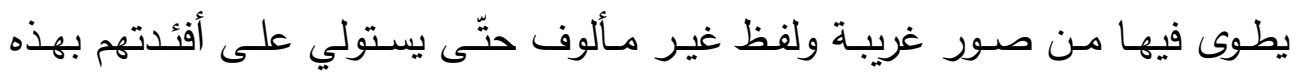

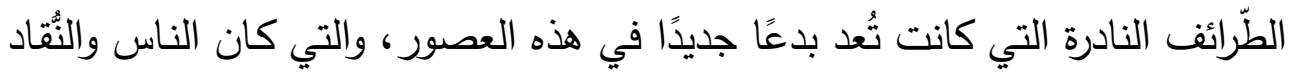
يقيسون بها مهارة الثاعر وإبداعه."

(شوقي ضيف، الفن ومذاهبه في الشعر العربي، ص: YVA) 
من الواضح أن الثغف بالمعرفة تكوّن عند المعري منذ طفولته فقد بدأ مشوار

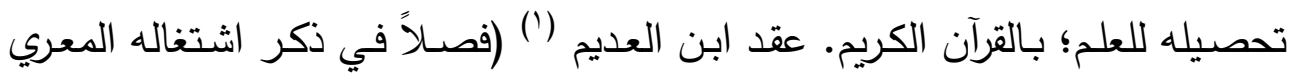

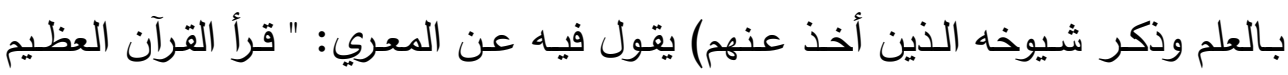

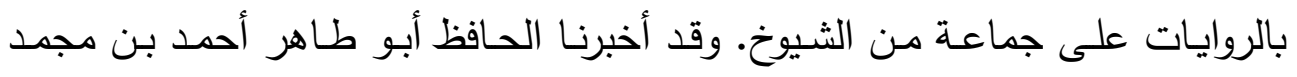

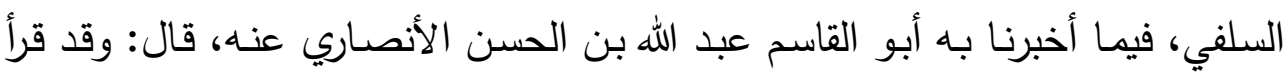

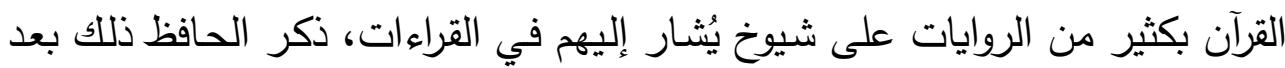

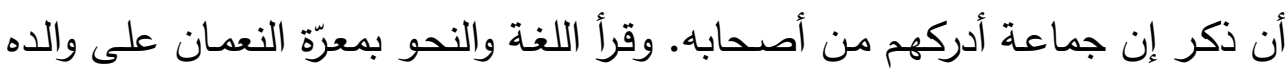

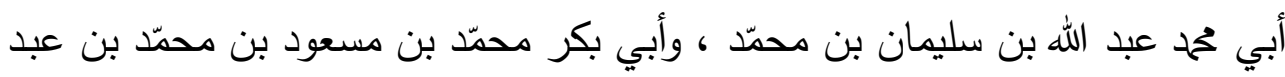

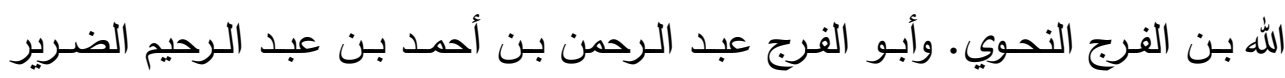

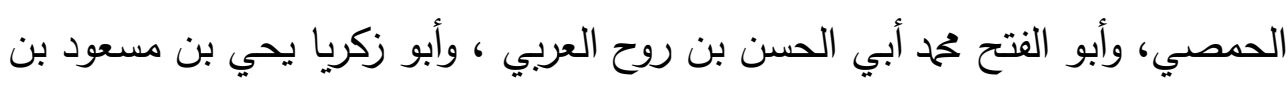

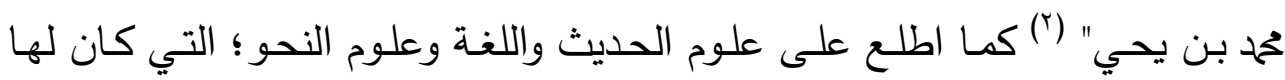
الفضل الأكبر في فصاحته وبلاغته وبيانه نتيجة انكبابه على دراسة العلوم الطبيعية

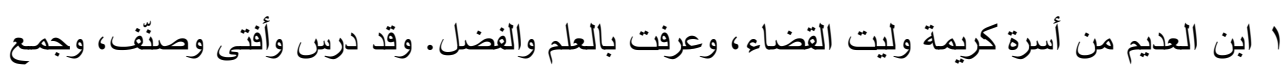

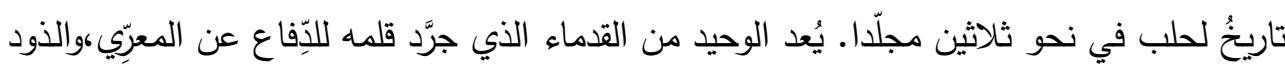

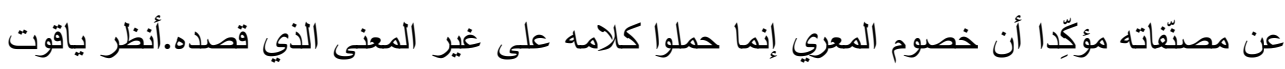

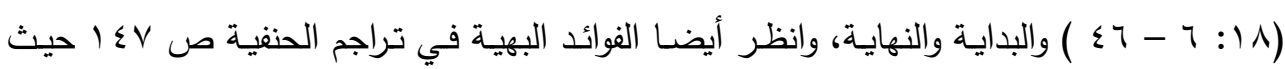

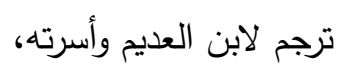

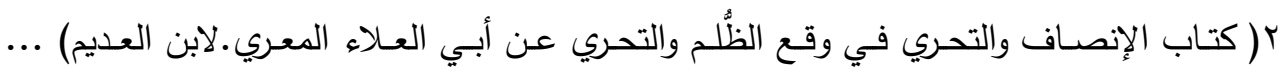

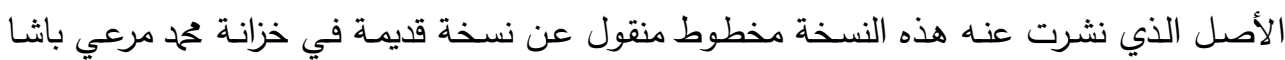

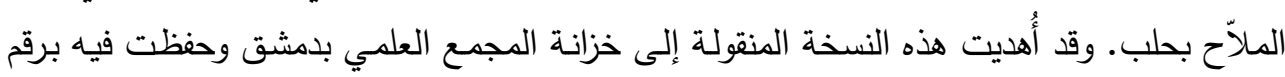

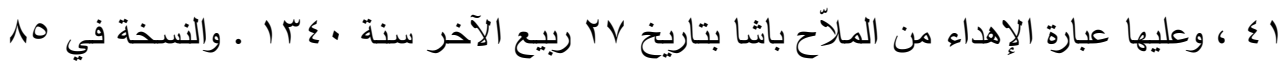

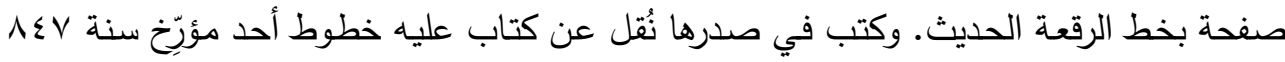

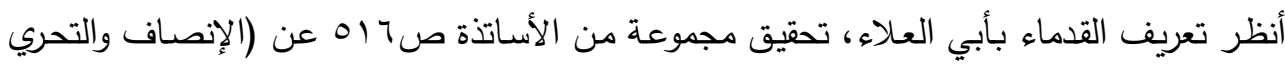

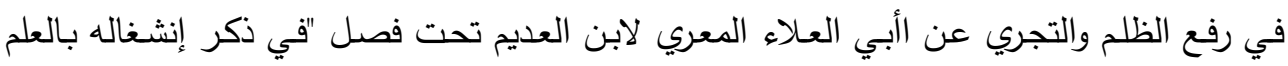

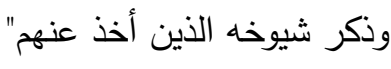




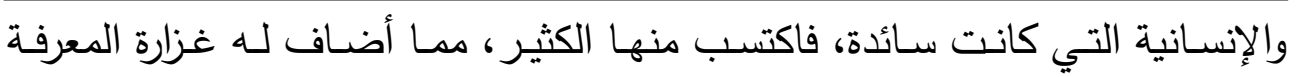
والعلوم الأساسية التي تعلمها

هذه الثقافة الواسعة التي اتسم بها المعرِيّ، كان لها معين آخر إضافة إلى عامل

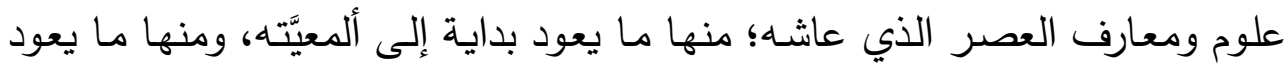

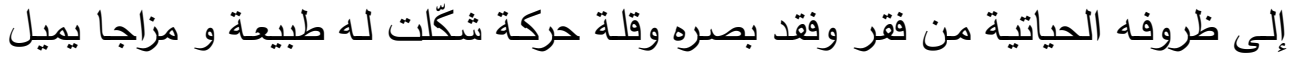

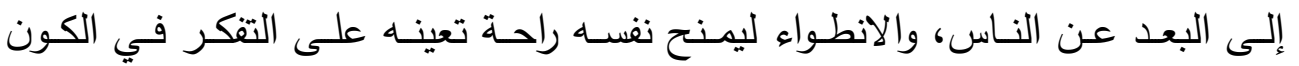

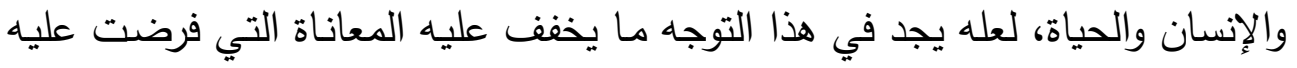
دون اختيار لها، إلاً أن رغبته في العلم والحصول على هلى مناخ وبيئة تستثمر العقول

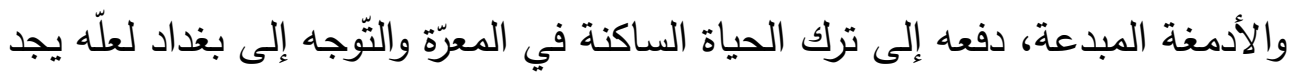

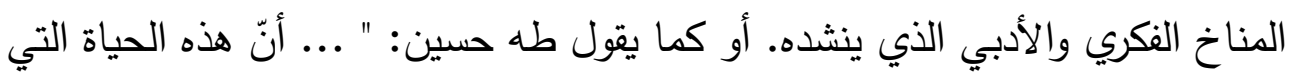

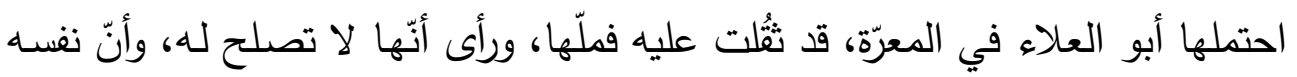

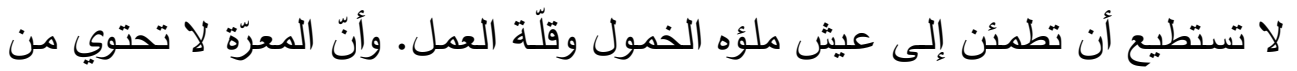

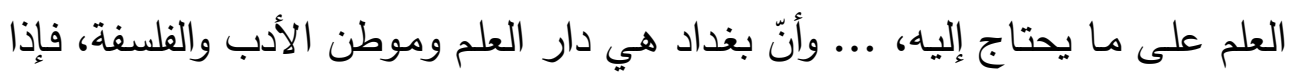
رحل فمن اليسير أن يجد ما يحتاج إليه من العلم والأدب، ومن الفلسفة والحكمة. "

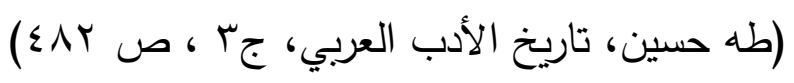

رغم أن المعرِي وجد في بغداد مناخ الأدب والحكمة والفلسفة، إلاً أنّه بطبيعته

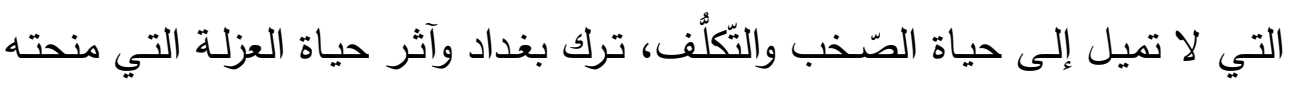

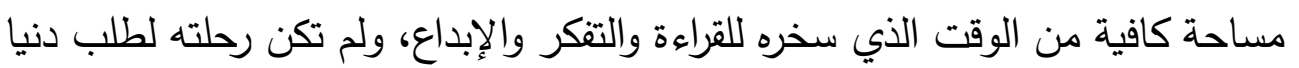

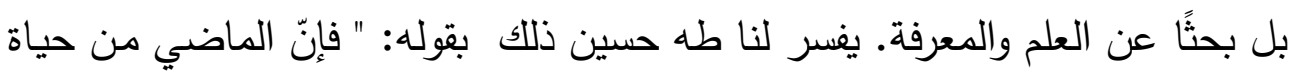

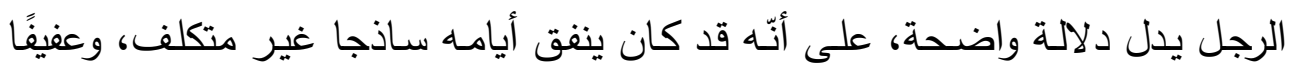

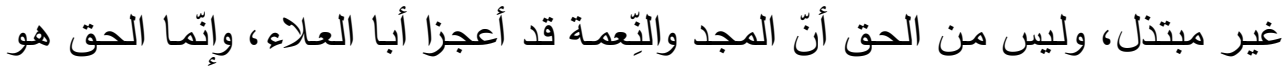

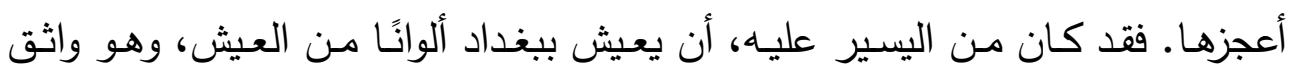

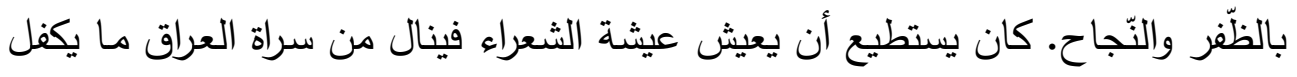


له الثروة والغنى. وكان يستطيع أن يعيش عيشة اللغويين، وأن يحيا حياة الفلاسفة في عصره. ولكنّه انصرف عن ذلك كله. فلم يرض إلاّ هذا السِّجن الذي أنفق بقيّة حياته فيهه ـ انصرف عن ذلك ، لأنّ فطرته تأبـاه، ولأنّ مـا اكتنف حياته من المؤثِّرات قد إلاته

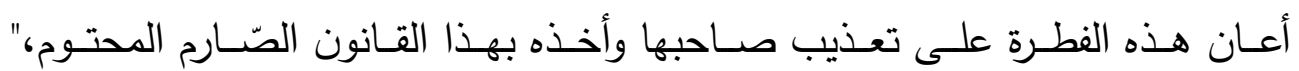

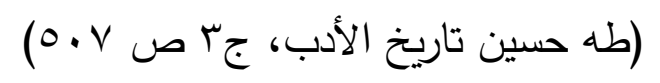

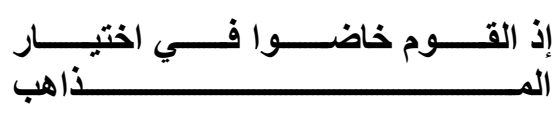

وهـنّ بنــــا يجــر ينجــري الستّـلاهب
وفي ذلك يقول:

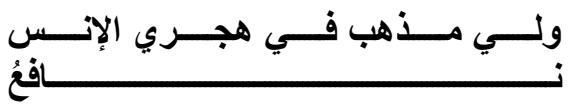

أرانــا علــى الســـاعات فرســان غــارة

(اللزوميات ج) (1 ص r (1)

لقد فضل المعري الوحدة على معاشرة الناس، لما وجد فيها من راحة عظيمة تخفف عنه ثقل أفعال الناس وشرورهم، معبرا عن ذلك بقوله: قَلبًا و في الكون بين الناس أثقال في الوحدة الرّاحة العُظمى فَآخ بها

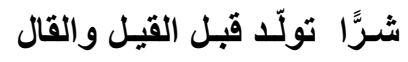

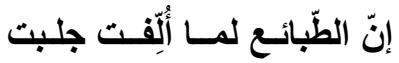

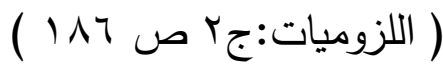

أوجد المعري لنفسـه عالمـا آثر فيه البعد عن الناس الذين لم ينصفوه، بل تكتّلوا ضدّه حسدًا وغيرة منه حين أدركوا إمكاناته الشعرية وغزارة علمه (') وفي ذلك يظهر ا يقول ابن العدبم، في كتابه "الإنصاف والتحري في دفع لظلم والتَّجري عن أبي العلاء المعرِيّ"

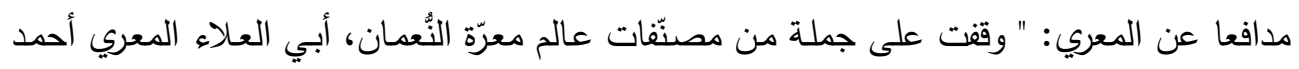

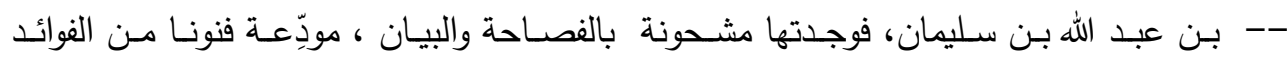

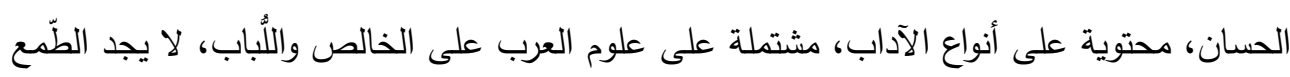

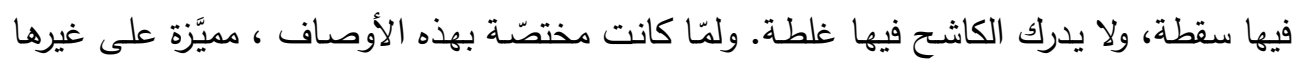

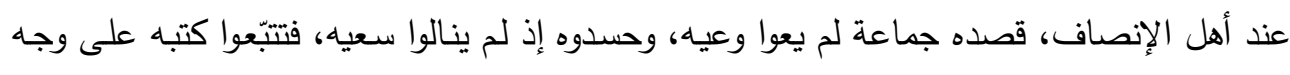


وجه من أوجه الحياة الاجتماعية التي يبدو فيها التناقض واضحًا في سلوك المجتمع الإنساني بين التظاهر بالفضائل والحقيقة التي تنطق بالنفاق والكذب. أو كما يقول: وعلمــــي بــــأن العـــالمين هبــــاء

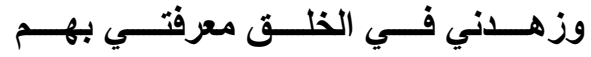

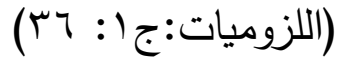

في هذا البيت يشير المعري إلى الواقع الإنساني الذي يصفه بالهباء، (') وهو يعني أن عزلته كانت بسبب ما وجدته في الناس من عدم إعمال عقولهم في الحق والصواب، ويقول مشيرا إلى الراحة التي يجدها في الوحدة بعيدا عن الناس:

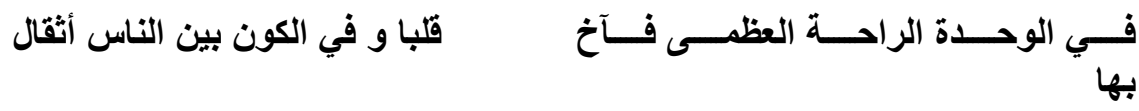

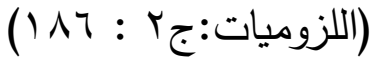

ومـا اتسـم بـه أهلها مـن جهل وطغيـان،بمتلف عقائدهم، فيظهر بعضـهم مـا في ضميره، ويخفي الآخر جاهدًا ما يكن ضميره من غل ونفاق وأحاديث كاذبة. وهذه الأنماط من الناس معروف أمرها وهو لذلك يتجنَّبها، أمّا ما يثير تعجَّبه فهو كيف أن الفئات الأخرى من الناس، حيث أثـار إليهِ متعجِبًَا بلغنة الجمع: " نقفوا" و "نترك". وهذا الذي أثار سخطه على المجتمع، وتساوت في نظره الأنماط من الناس الفاسد منهم والصالح الذي يترك الجهل والفساد يُشـاهد؛ وهذا هو الضـلال في رأيه، حيث لا يمكن أن يكون بين هذه الأنماط من الناس؛ زاهد يعمل على الإصسلاح، مؤكدًا زهده في الدنيا، وكرهه لها. يقول:

الانتقاد، ووجدوها خالية من الزيخ والفساد؛ فحين علموا سلامتها من العيب والثِّين، سلكوا فيها معه مسلك الكذب والمين، ورموه بالإحاد والتعطيل، والعدول عن سواء السبيل، فمنهم من وضع على الى

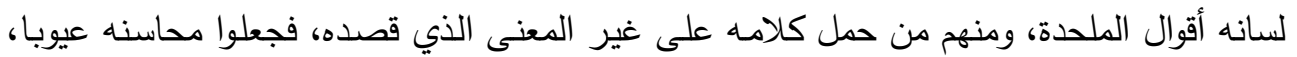
وحسناته ذنوبا، وعقله حُمقًا، ... وحرَّفوا كلمه عن مواضعاه، وأوقعوه في غير مواقعه " ا ورد في لسان العرب؛ الهباء يعني الناس الذين لا عقول لهم. 
لـــتملم ســــرًا فــــالعيون ســــــواهد

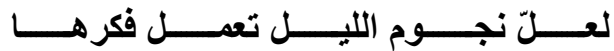

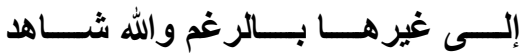

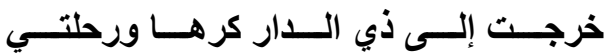

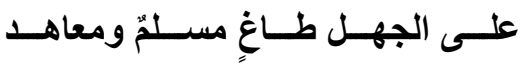

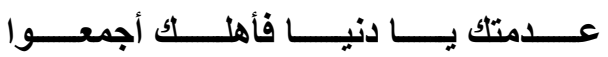

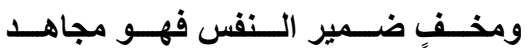

فمفتضـــــــ يبــــــي ضـــــــائر صــــــره

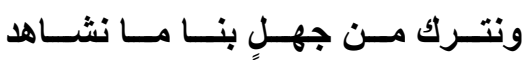

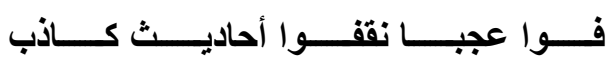

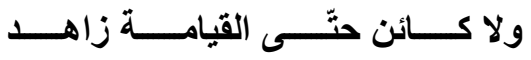

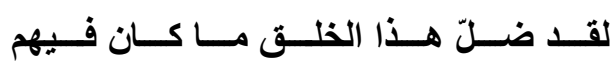

(اللزوميات: ج)

هكذا خرج المعري من عزلته برؤية مفكر زاهدًا عن بعض مظاهر الدنيا وأهلها،

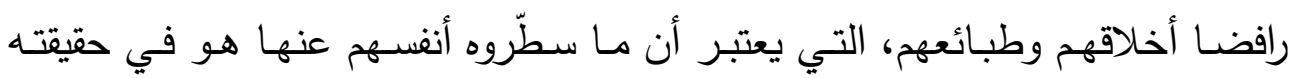
فضيحة لهم. وهنا نلمس رؤية عميقة للمعري عن ما جُبل عليه الإنسان من الطبائع الذميمة التي سطرتها أيديهم، وقد وثق تأكيده لهذه الطبائع المذمومة من جانبه، بعلم الله تعالى بها ويتمثل بعض منها في بطر العباد عندما يمن الله عليهم بالرزق ذلك أن الله تعالى يعلم هذه الطبائع فهو خالقهم. يقول في هذا المعنى ناقدًا ورافضًا لمثل هذه

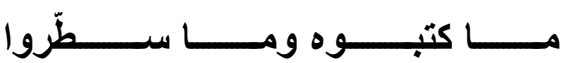

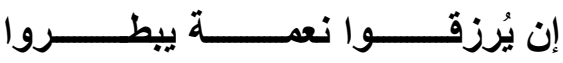

فأعجـــــب مـــــن ذالك أن يُمطــــــروا

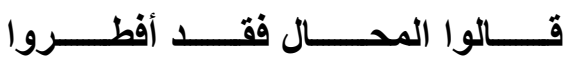

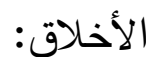

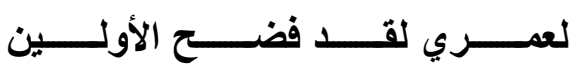

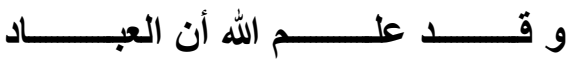

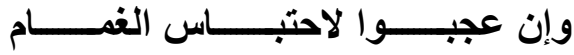

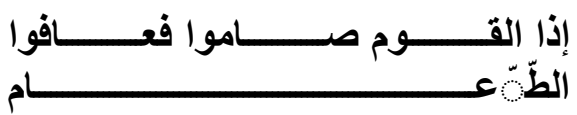




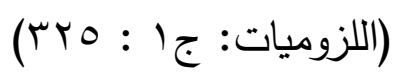

إضـافة إلى هذه الرؤيـة العميقـة للمعري عن أخـاق وطبائع النـاس والتي يبدو

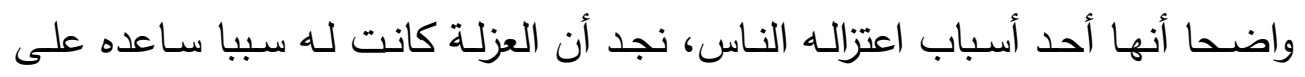

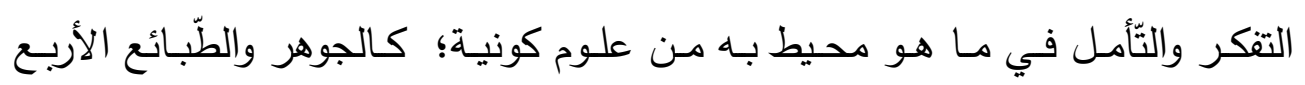

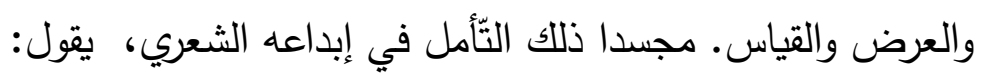

نــــارِ ومــــاءٍ وتربــــة وهـــــوا

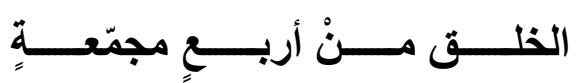

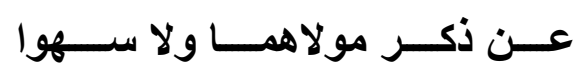

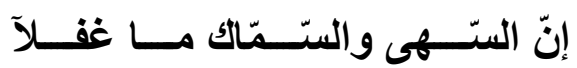

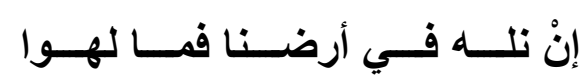

والنيــــــران الموصــــلان ســــنـا

يطعـــم أهــل الــبلاد مــــــــوا

والثـــمس والغيــث طاهيــان لـــه

(اللزوميات:جن :

يرفض المعري أخلاقيات كانت سائدة في المجتمع، تتمثل في الكذب والمكر والغيبة

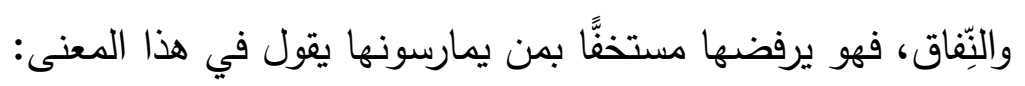

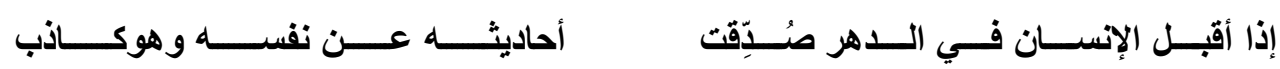

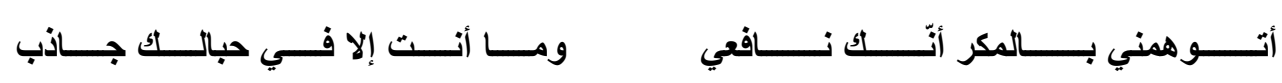

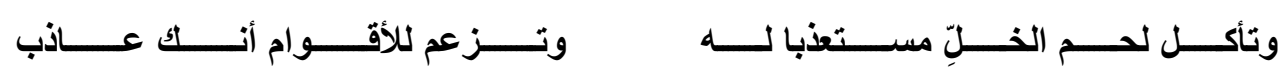

(اللزوميات: ج ا : (TV ) 
بل هو يؤثر مخالطة الجماد على مخالطة الإنسان، لأن سلوك الإنسان وأخلاقياته لا تروقه لما فيها من التناقض والتنافر فمرآهم قد يبدو حسن، إلاّ أن حقيقتهم تناقض الظاهر لأنهم يميلون إلى النفع والكذب والظلم يقول:

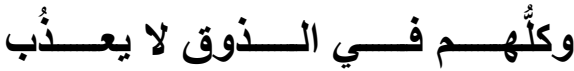

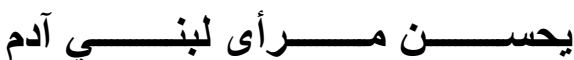

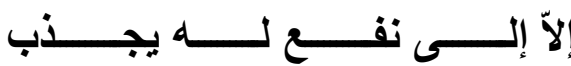

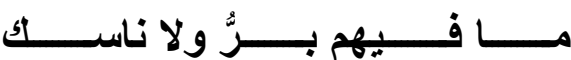

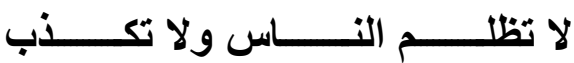

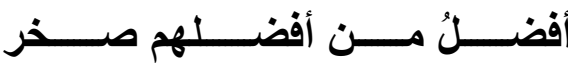

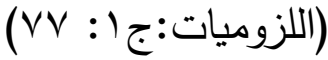

انعزال المعـري عـن المجتمع، كـان بمثابـة ردة فعـل لمـا كـان سـائدا مـن فسـاد أخـلاق، وكـان لـذلك الانعـزال أثر كبيـر في تركيزه على الكـون وظـواهره. وربطها

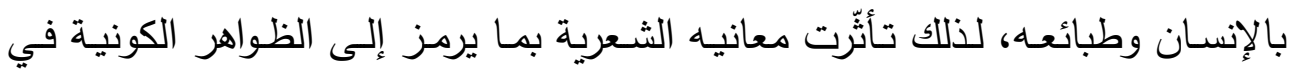
حديثه عن أخلاق الإنسان، ظهرت تلك المعاني في أوجه عديدة من شعره؛ على سبيل المثال؛ الاختلاف بين ما تدل عليه معاني النجوم والكواكب، وإن تشابهت الأسماء بينها وبين الإنسان، مبينا الفرق بين ما تشير إليه معاني أسماء تلك الكواكب وما يتسم

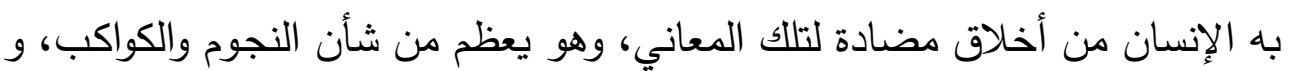
يحط من أخلاق الإنسان الذميمة التي تجذب الشر، وهذا هو حال الإنسان في رأيه، مهما يتظاهر بالسمو في استعمال أسماء النجوم والكواكب. يقول:

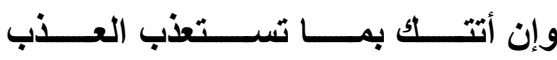

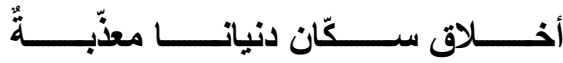

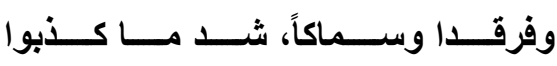

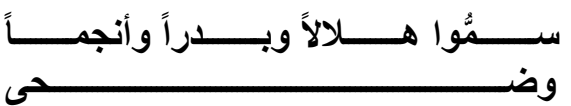

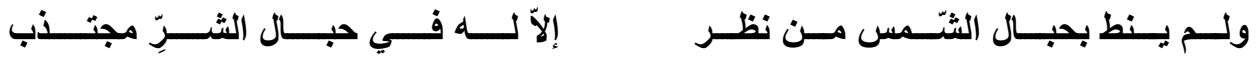




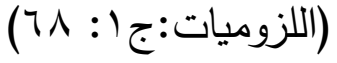

من الواضـح أن ثقافة المعري العميقة جعلته ملمـا بالفلسفة الإغريقيـة، متأثر بهـا،

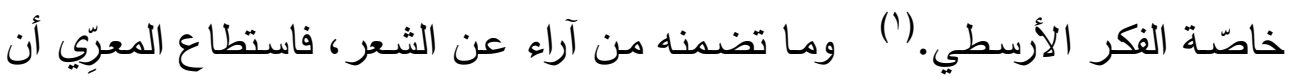

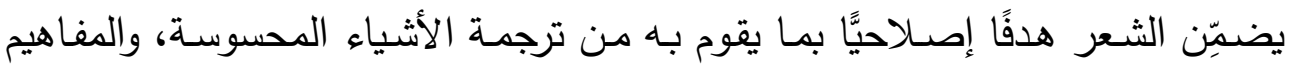

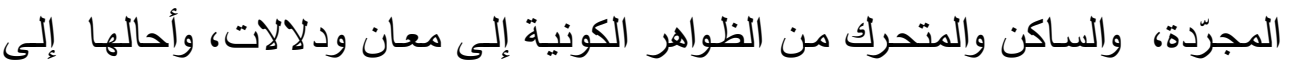

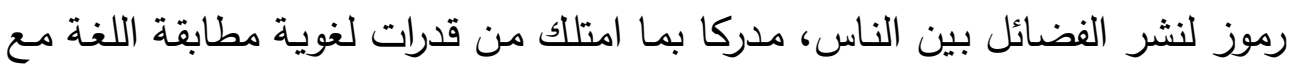
الظواهر الكونية من حيث التركيب اللغوي و طبيعة الظاهرة الكونية وكذلك علاقتهما

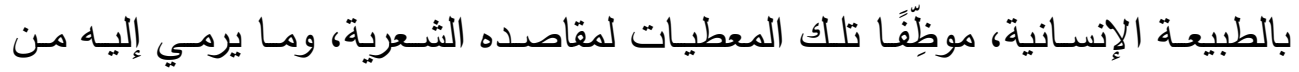

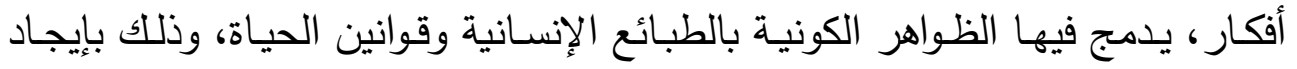
علاقة بينها (' ) يقول في هذا الثأن:

ا يرى أرسطو أن الثعر يتضمّن هدفًا إصـلاحيَّا لأنه يعمل على تخليص الإنسان من التراكمات

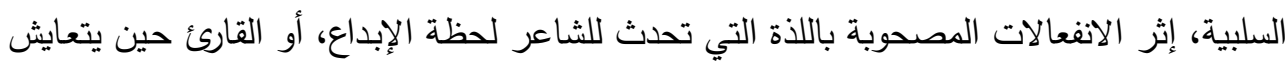

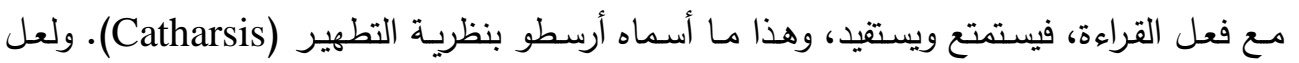

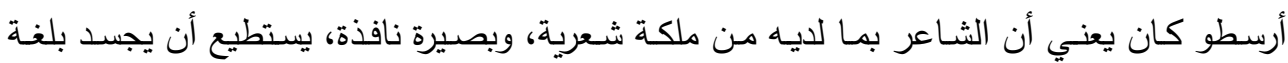
الشعر أفكارا ويترجم معانٍ عن الحياة والكون، مـا يعجز غيره عن الإتيان بـه، لذلك يعتبر الشـاعر معلما وفيلسوفا

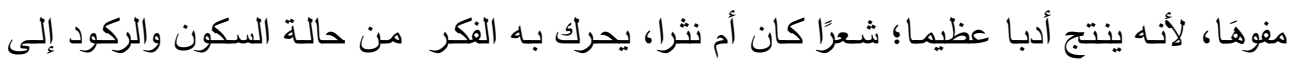

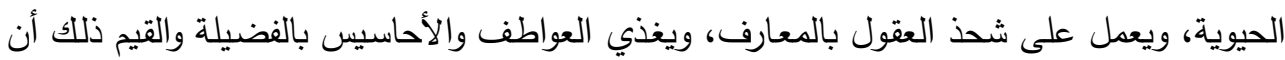

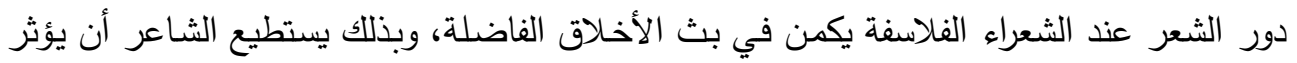
في الفكر الإنساني، فتأخذ الفضيلة مكانها في الحياة، ويكون الشعر هو الدصدر المناسب لتعليمها

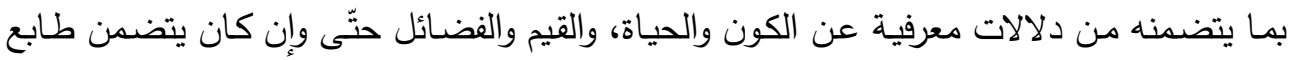

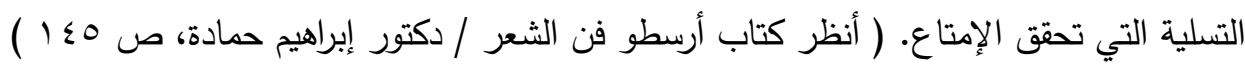

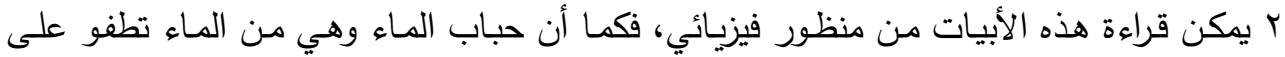

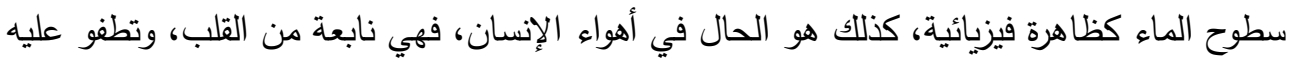
وعملية كظاهرة بشرية الطفو هنا يدل على أن الأهواء تهيمن علي الإنسان فتتنامى وتزداد. 


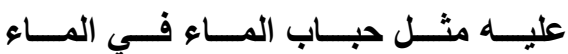

القتهــــب كالمـــــاء والأهـــــــواء طافيــــة

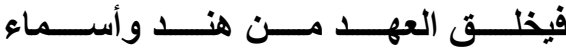

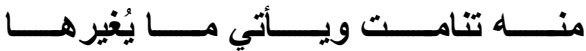

والنــاس كالــــهر مــن نـــور وظلمـــاء

والقــول كــالخلق مــن ســيء ومسن حسـن

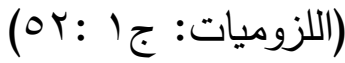

و بأسلوب مجازي يوجد تقارب بين أفعال البشر والظواهر الكونية؛ فمثلا كما يسعى الإنسـان لرزقه، كذلك تسعى الأرض لرزق تقتات منه ف فتأكل من (الأنام وتشرب)، وهو هنا يربط بين الحقائق البشرية والحقائق الكونية، فالإنسان في حياته يسعى جاهدا لرزقه وقد يقتات من الأرض ليعيش، والأرض كذللك تقتات منـه لتبقى مكوناتها مـا بقيت الحياة. يعقد هذه المقابلة بين الإنسان والأرض، لكن ما يعنيه هو النظرة الفلسفية العميقة التي أوجدها بين الحقائق الكونية وحقيقة الإنسان، يقول:

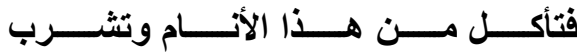

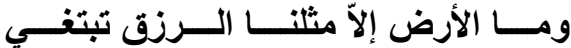

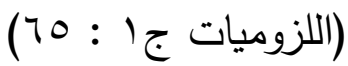

و من خلال استعماله لمفردات اللغة المجازية وأسـاليبها البلاغية، يشير المعري إلى العلاقة التي بين فقد العلمـاء و بين مفهوم الجهل؛ ومستعملاً الظلمـة كظاهرة كونية، لغرضـه الذي يريد بـه أن فقد العلمـاء هو سبب في انتشـار الجهل. وبمـا أن الجهل يطابق الظلمـة في مدلوله، فعقول عامـة الناس تكون مظلمـة إن فقد المجتمع ذوي العلم والمعرفة، إذ أن غلبة عامّة الناس يفتقدون العلم، ونتيجة جهلهم لا يرون الأمور بوضوح، فالعلم ينير القلوب والأذهان لتدرك آيات الله في الكون. يقول في هذا المعنى : (x)

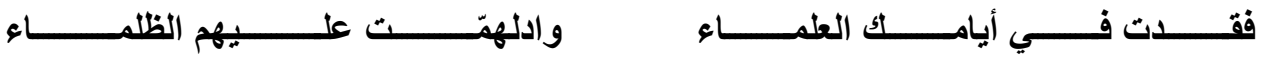

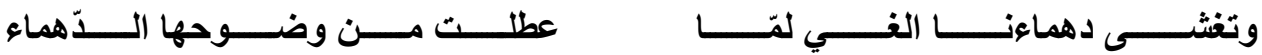




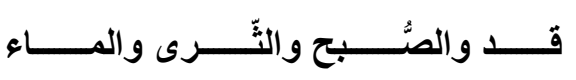

رةُ و الأرض وض والضـــــــــى والستــــــــماء

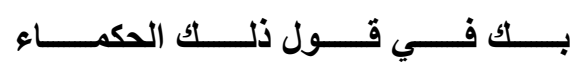

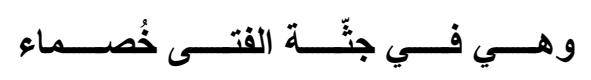

(اللزوميات:ج (: 0 ؛ -7 )

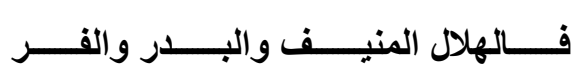

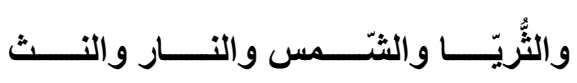

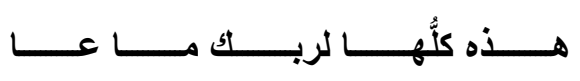

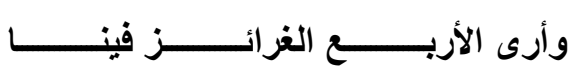

\section{اللفة ومطابقتها للظواهر الكونية في شمر المعري:}

حين يستخدم المعري الإحالات يشير بها إلى أمور قد لا يرمي إليها لذاتها، بل

$$
\text { يمنحها تحويرا دلاليا }
$$

باللغة المجازية وبلغة التشبيه والاستعارة، التي تتميز بها اللغة بصفة عامّة، والشعرية على وجه الخصوص، والناتجة عن إمكاناتها في الاستدلال على طبيعة العالم ، فهي التي أمكنت شاعرنا أن يستثرها في إثاراته إلى المعطيات الكونية والحياتية في البناء

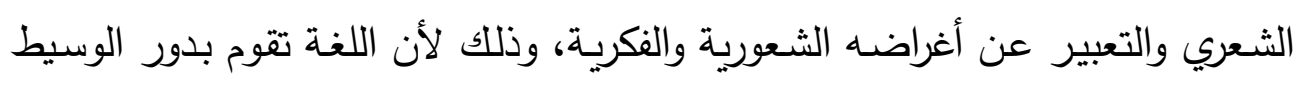
بين الأشياء والأفكار وبين ما يرمي إليه الثاعر ، لما تتضمنه من نظام رمزي وأنساق وتراكيب تمنح الأشياء معنيين وتعطيها وجودا مختلفا عن الوجود السابق. (أنظر :حمح

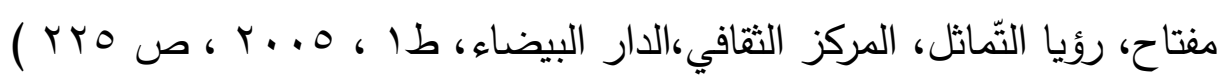
تحدث المطابقة بين اللغة من حيث تركيبها، ومن حيث طبيعة الأشياء خارج هذا التركيب اللغوي، ويحدث التلاعب بالألفاظ ومطابقتها مع الموجودات خارج مدار 
اللغـة؛ فيمنح الثـاعر الجماد صفة العقلانيـة، التي هي من سمات البشـر ، فيشكل

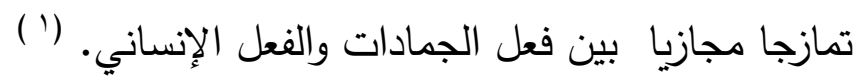
بهذا المفهوم فاللغنة لا تمبِّل الفكر الإنسـاني فحسب، بل تشير إلى معان ودلالات

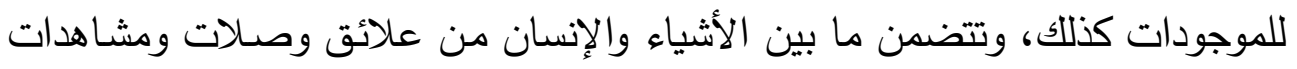

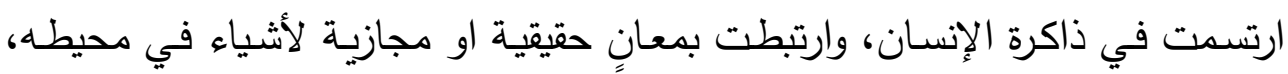

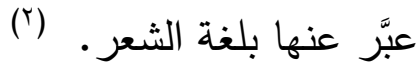

ا هذا التميز في اللغة الشعرية هو ما دعا الشعراء والعلماء البارزين في اللغة يضعون لغة الثعر

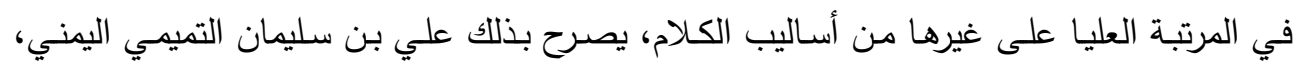

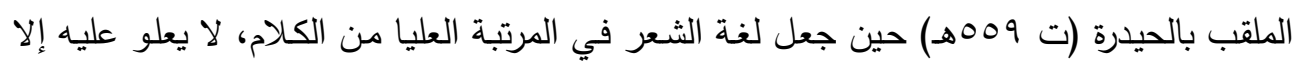
كلام الله ورسوله، يقول: " أما الشعر في نفسه فهو الدرجة جلهد العليا من الكلام كله، بعد الكلام الإلهي

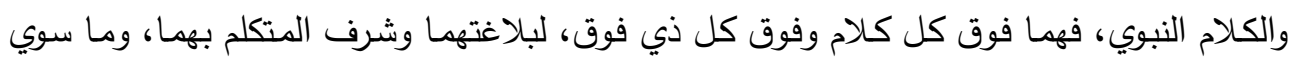

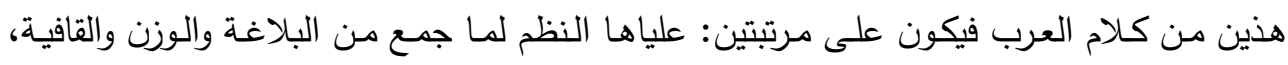

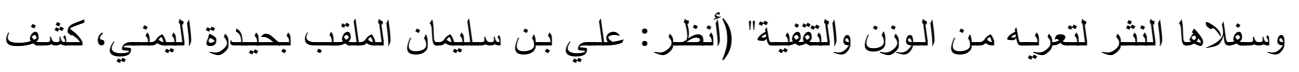

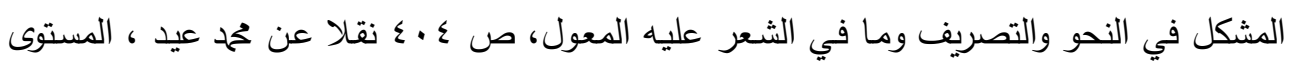

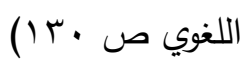

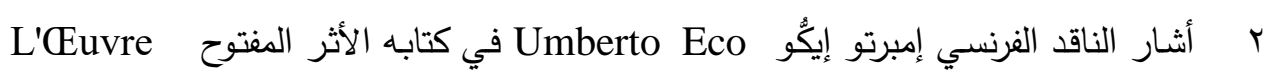
ouverte موسوعة من المعارف الكامنة في الأشياء المحسوسة والمتخيلة ، كذللك في المفاهيم والقيم المتمثلة

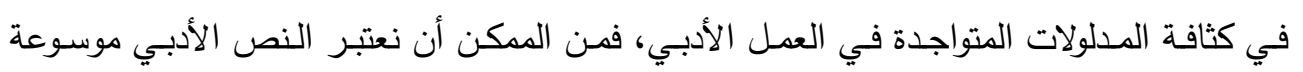

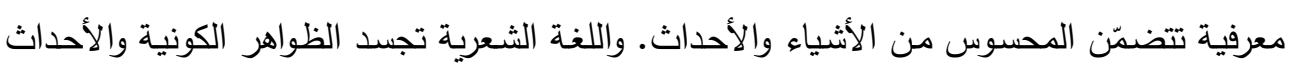
الحياتية في تثكيل له من الخصوصية ما يجعله يحمل دلالات مختلفة تتسم بالتتوع والإحالات التي لتصني

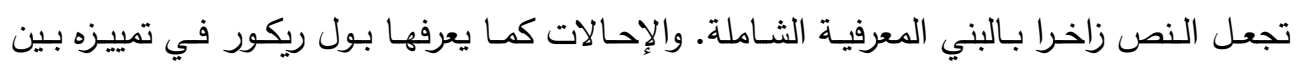

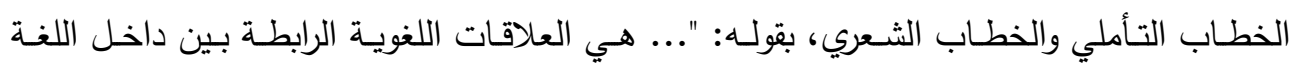

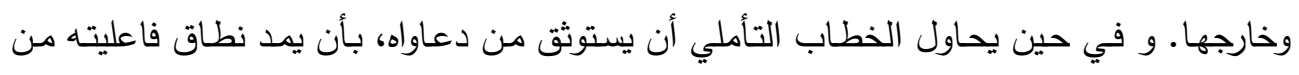

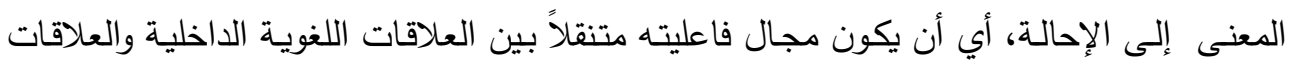

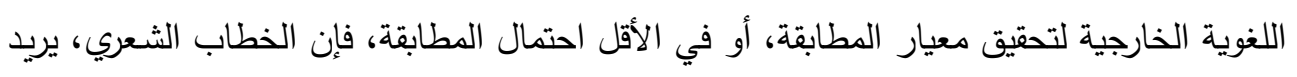


عنـما نـرى في الثـعر انعكاسـات للظـواهر الكونيـة التي يرسـهها الثـاعر بلغتـه المجازية، نجد التجانس واضحا بين اللغة الثعرية والظواهر الكونية في شعر المعري (') حيث استطاع المعري بما امتلكه من إمكاناته اللغوية وخلفية معرفية عن معارف عصـره أن يـربط بين اللغـة في دلالاتها الصـوتية ومـا يضـــها إياهـا مـن الظـواهر الكونية، بمـا يبرهن لنا أن "هذا الكون المرتب والمنظم المحقق لحكم معينـة والسـائر نحو غايات محددة موجودة طبعًا وما صناعة المعرفة بالمقاييس والبراهين إلاّ كاشفة

أن يكتفي بالمعنى وحده، خالقا بذلك إحالته الخاصّة في داخل العلاقات اللغوية الداخلية وهذا هو

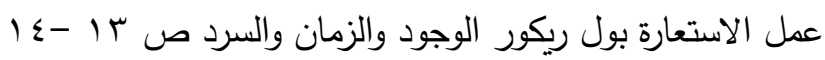

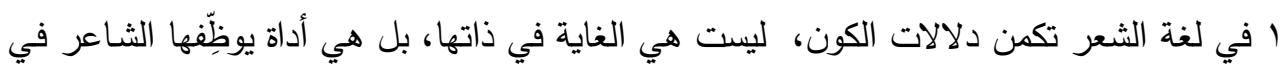

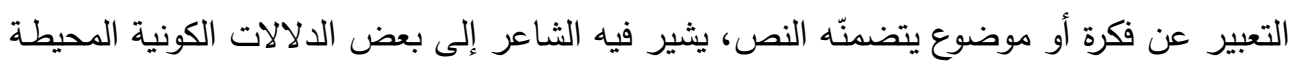

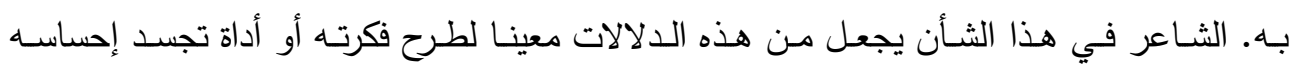
ومشاعره. هذا الأسلوب الذي يلجأ إليه الثاعر ناتج عن إدراك عميق لديه بما لداء تحمله بعض الظواهر

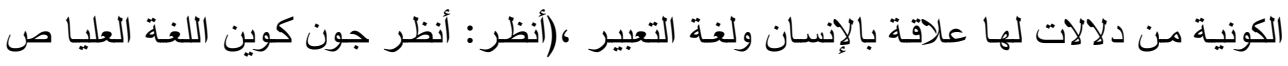

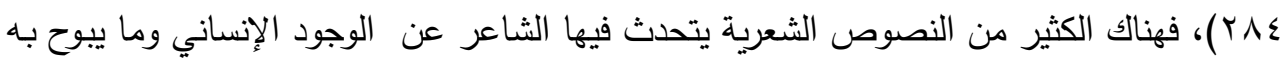

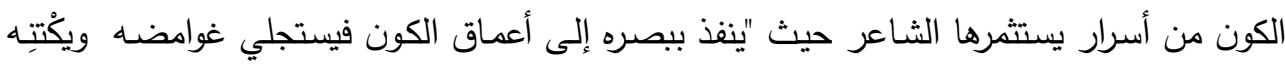

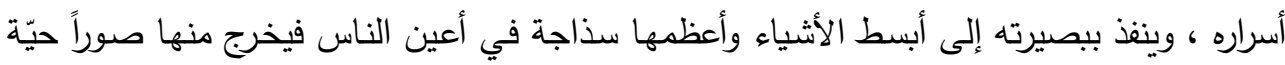

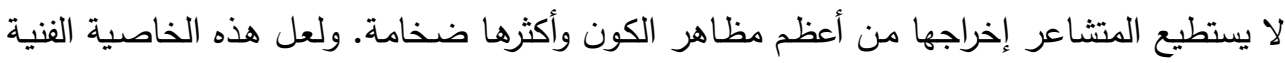

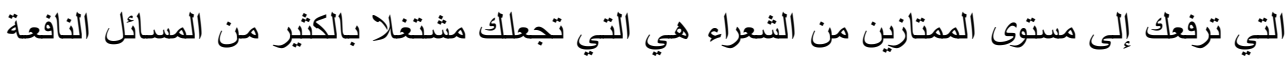

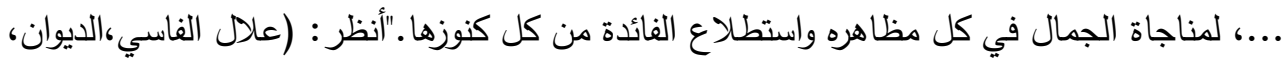

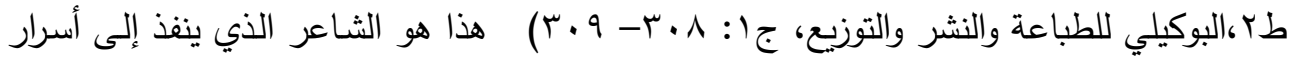
الكون ببصيرته النافذة، وخياله، يستطلع المعرفة من أصغر جزيئات الكون الفسيح، ليخرج بنسيج

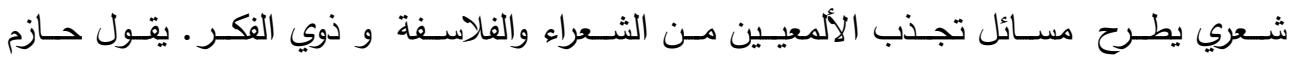
القرطاجنّني:" محصول الأقاويل الثعرية تصوير الأشياء الحاصلة في الوجود وتمثيلها في الأذهان

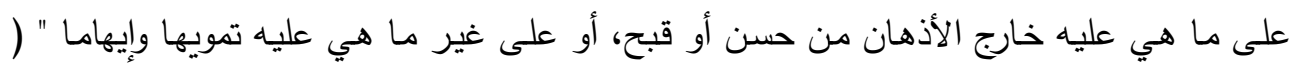

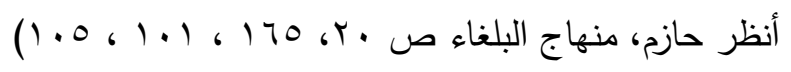


عن موجوداته ونظامهه وترتيبه...." (مشكاة المفاهيم ص VT) فاللغـة الشعرية تعطي الأشياء التي تتكلم عنها، دلالات متعددة، إضـافة إلى انها تعبر عن موقف المتكلم عن هذه الأشـياء، لذلك يكسون النص و الثـاعر عندما يلتقط خيـوط العلاقـة بـين الأشياء، يحدث حركة فكريـة وجدانية في ذاته وفي ذات الآخرين، وهو بذلك يؤكّد ارتباط الشعر القوي بالدلالات الكونية مدركا أن كل شيء في الكون له معنى، وأن كل منظومة من العلوم المتباينة ذات صلة بهذا الكون مليئا بإحالات تشير إلى العالم الخارجي في حركته وسكونه وعلاقته بالإنسان. (') يقول المعرِي في هذا الشأن:

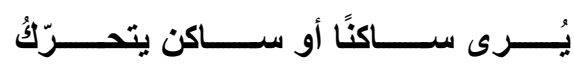
ونحـــــن بعلـــــم الله مــــن متحــــــرِّك

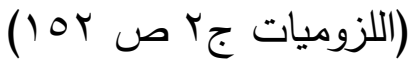
ويقول: ســـكونًا خـــــت أقــــدم مـــن حـــراك ا ل "انقسم الفلاسفة إزاء العلاقة القائمة بين ألفاظ اللغة وبين حقائق الكون إلى ثلاث طوائف: طائفة

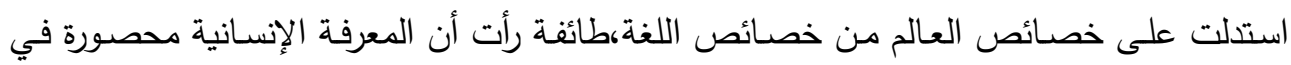

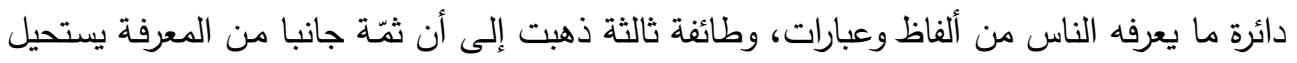

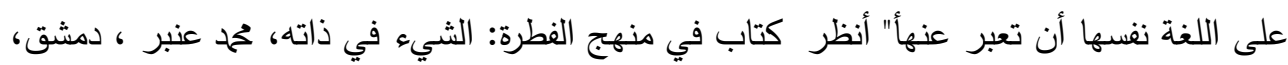

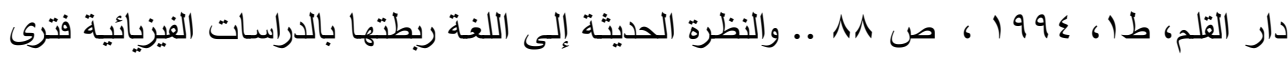

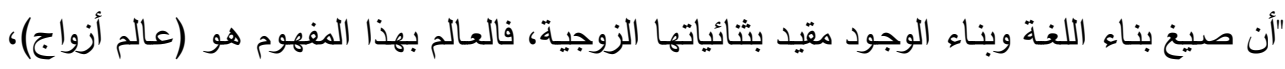

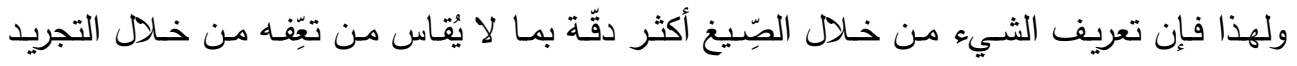

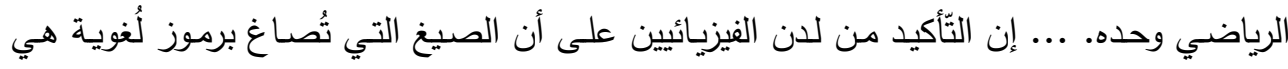

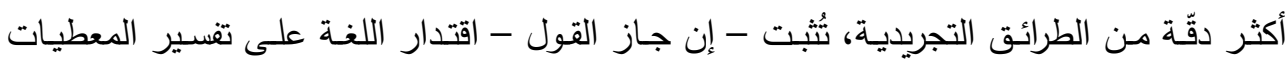
الكونية والحقائق التي تثير إلى حركية الأشياء في هذا العالم بصيغة تتناسب مع الطبيعة الكونية

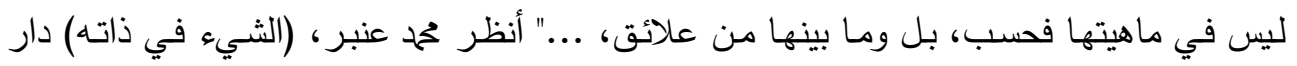

$$
\text { القلم، دمشق، } 199
$$


(اللزوميات جr : ror )

فالحركة والسكون ( - " ) صفة تجمع بين (الإنسان والكون واللغة)، فالإنسان في

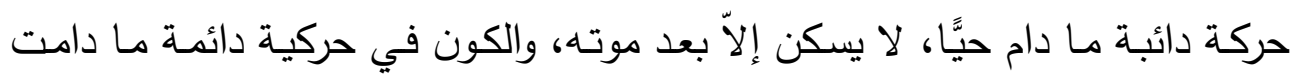

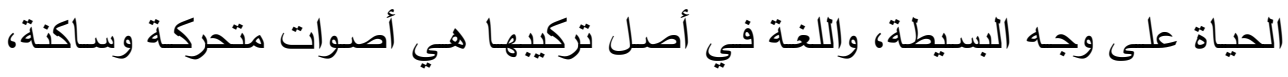
تتطابق مع حركة وسكون الأشياء في العالم الخارجي، وبذللك ندرك كيف تتناغم اللغة

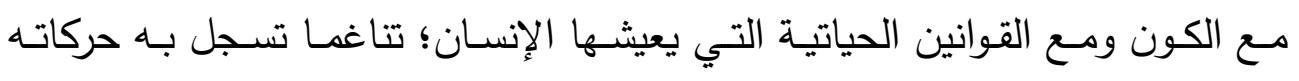

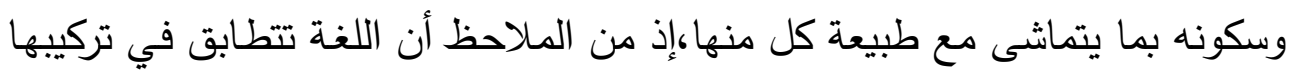

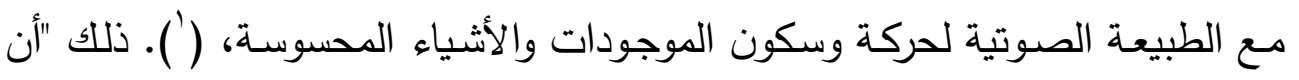

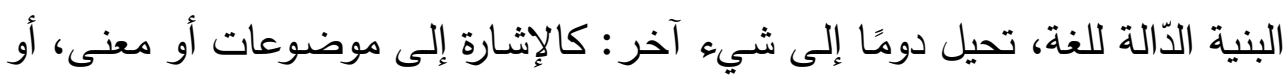

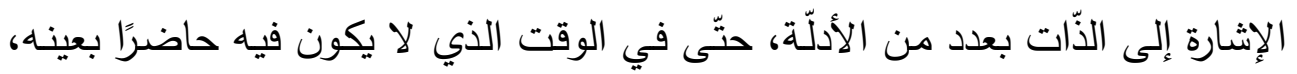

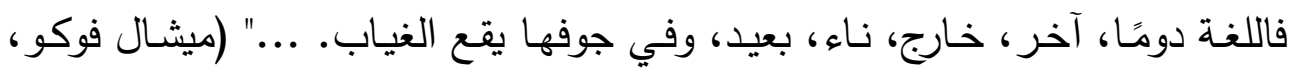

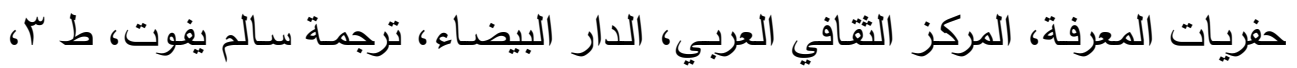

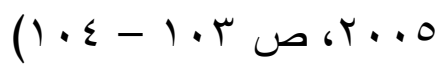

ا إن خيوط العلاقات بين الأشياء كامنة في ذات الأشياء مثلما هي كامنة في طبيعة العلاقة بين

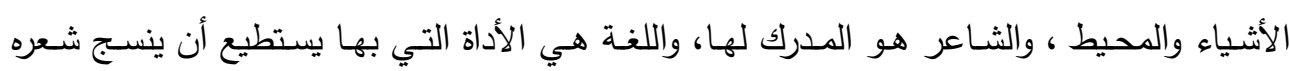

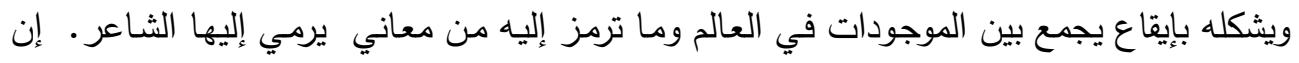

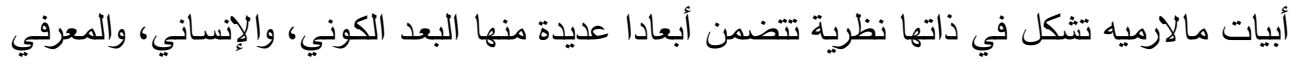

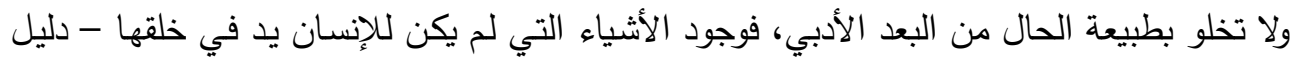

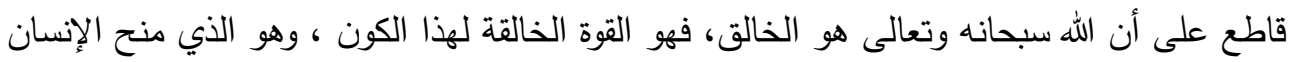

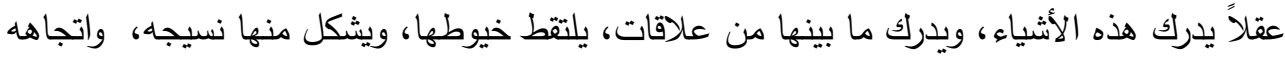

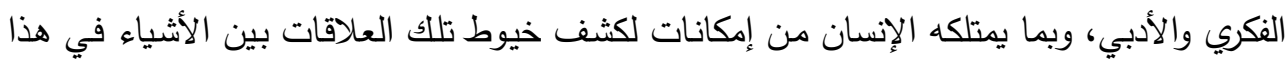

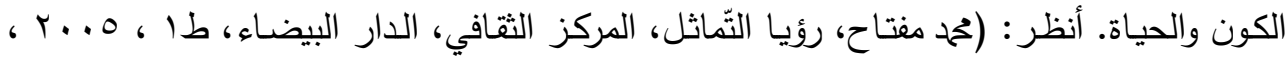

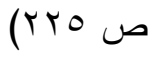


فالأرض بما فيها من جبال وبحار ، وأزهار ، وأشجار ، والسّماء بكل ما فيها من

كواكب ونجوم، تتجسّد أشكالها وأصواتها في مفردات اللغة، واللغة دوما تحيل إليها. فبنية الظاهرة اللغوية هي في مجملها جزء من بنية الكون. يقول ابن جنّي في هذه

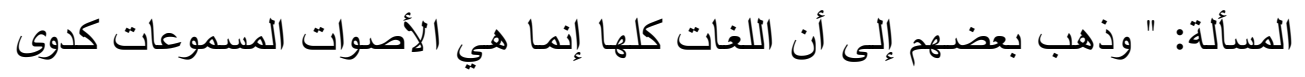

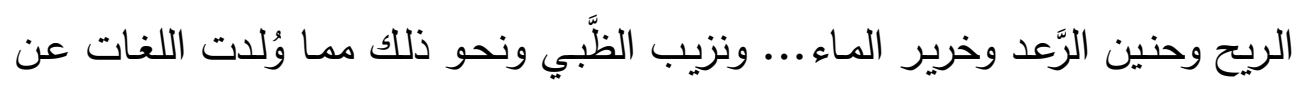

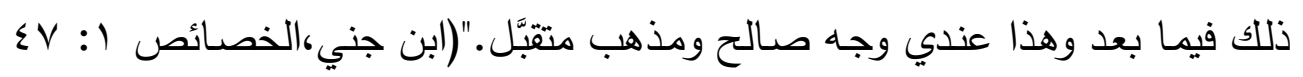

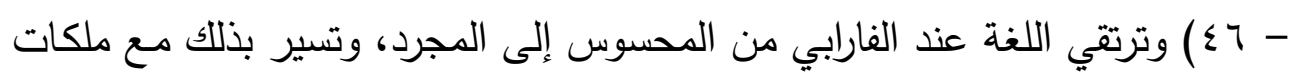

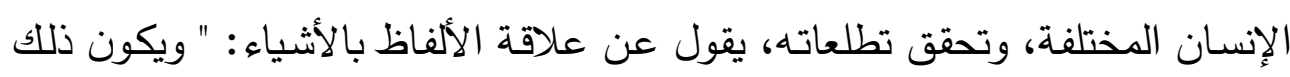

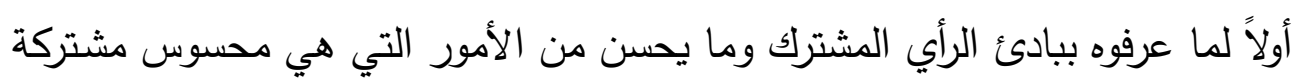

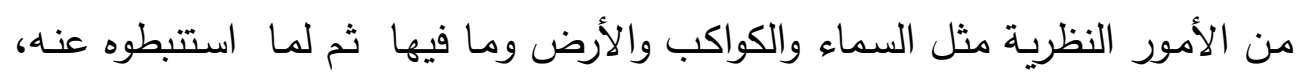

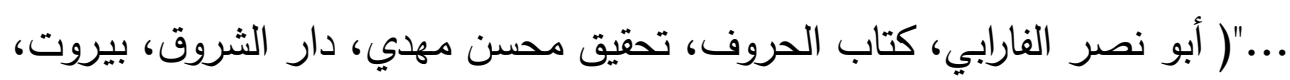

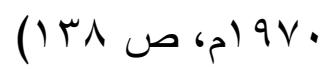

لقد تجـاوز المعرِّي المـألوف في امتلاكهـ ناصـية اللغـة ، و مـن ثمّ تضمينها

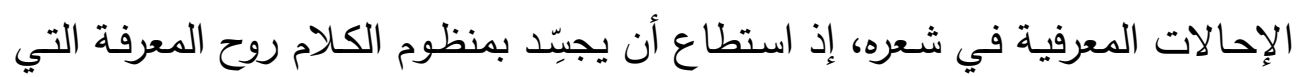

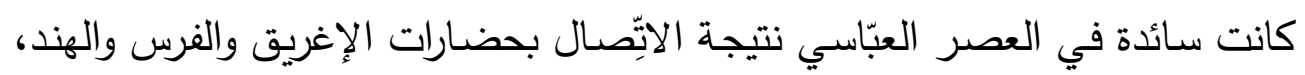

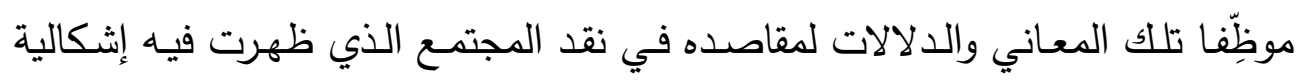

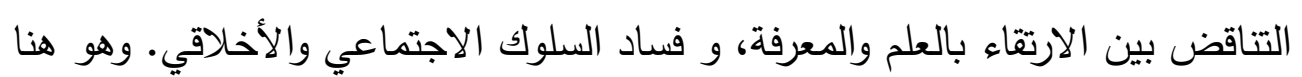

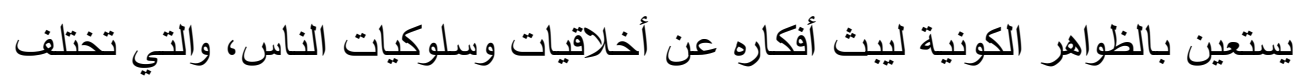

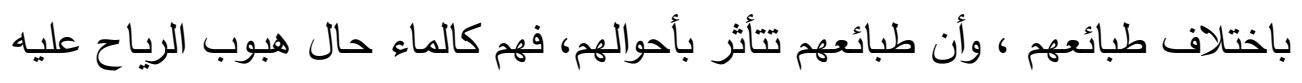

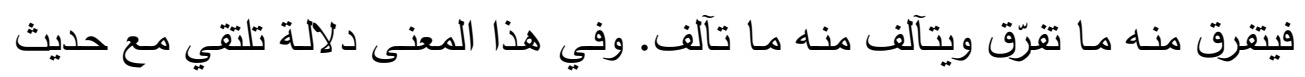

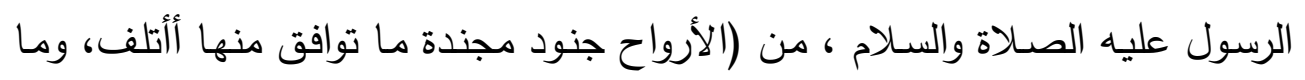

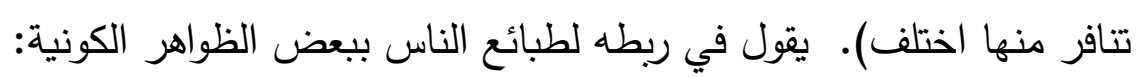

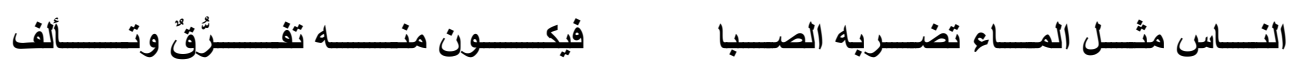




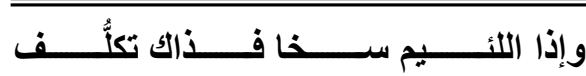

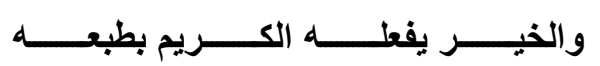

(اللزوميات جr : (1) (1) (1) (1) (1)

لا شك أنّ هذه الرؤية العميقة في نظرة المعري للطبائع الإنسانية، والتي تساوت فيها شرائح مختلفة في المجتمع؛ العميان منهم والمبصرون، الشباب والكهول، حتّىى تأصلت فيهم فأصبحت كالغريزة، تشير إلى معرفة بطبائع الناس وأخلاقياتهم، وإن فئن

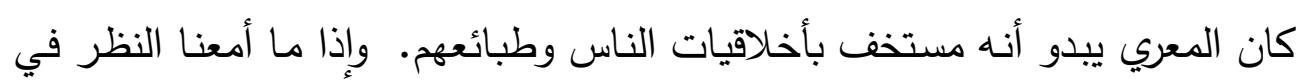
هذه الرؤيسة التي ربطت الثـعر بمعرفة طبائع الناس، نجد أنها قد تكون نتاج تأثره بالرؤية التي انبثقت من نظريـة المعرفة التي تبحث في مسائل تتعلّق بالكون والحياة (') والإنسان. يقول في سجايا الناس وأخلاقهم:

توارثهــــــــا أُنـــــــاسٌ عـــــن أُنـــــــاسِ

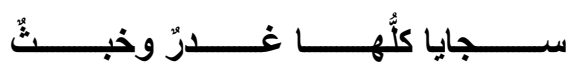

$$
\text { (اللزوميات جr : ( }
$$

ويقول:

وحيــــاً ولا تصـــــب خلــــلاً تنافة

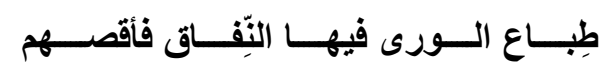

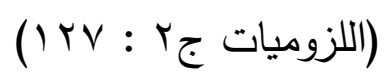

ا صنّفت المعرفة إلى أنواع أو مذاهب ثلاث؛ وهي المذهب التجريبي الذي يرى أنّ التّجربة هي

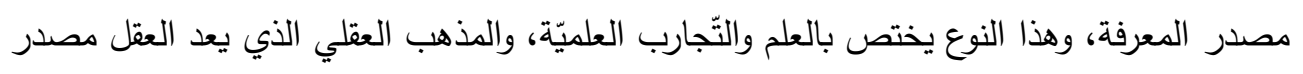

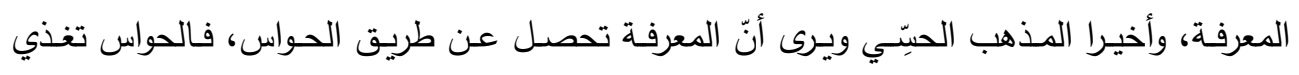

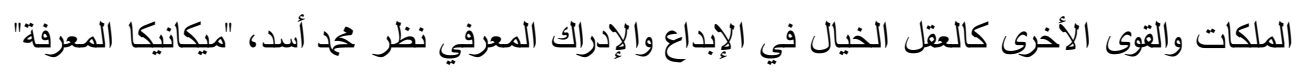

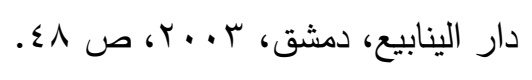


استدلال المعري بالظواهر الكونية في شعره، يعبر عن رؤيته العميقة في ارتباط الإنسان بالكون الدحيط به؛ سواء في طبائعه أو تكوين شخصيته، أو قدراته الفطرية

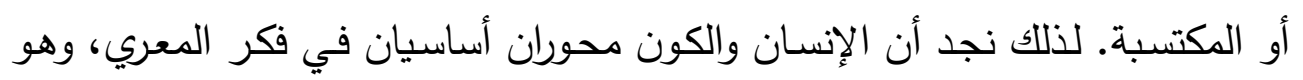

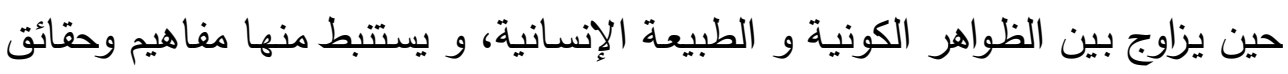

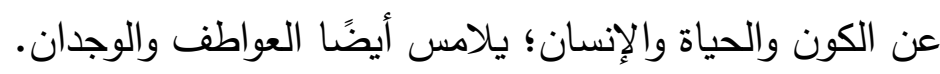

لاللك فالأفكار التي يتضمّنها شعر المعري، تستوجب إمعان النظر بعمق وروية

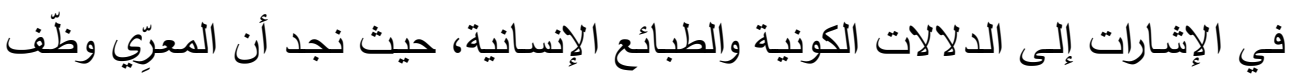

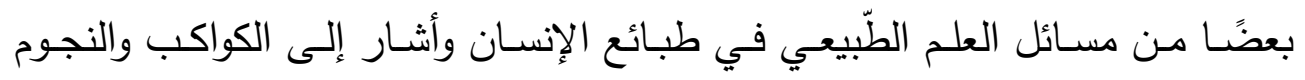

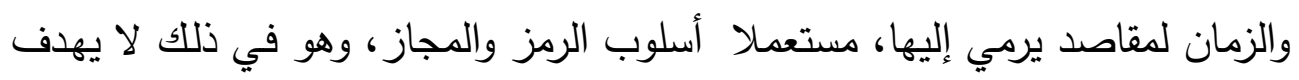
إلى ذكر الحقائق لذاتها، فهو كما يقول:

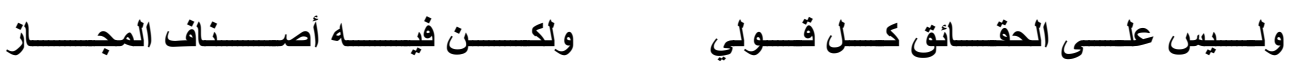

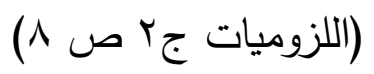
هكذا يكثر المعري من الدلالات التي تشير إلى العلاقة بين الإنسان والظواهر

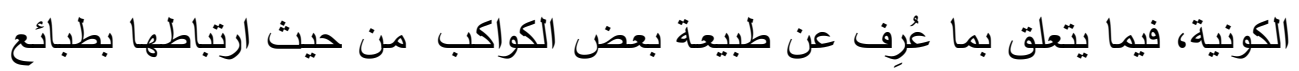

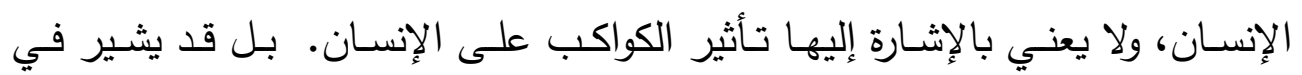

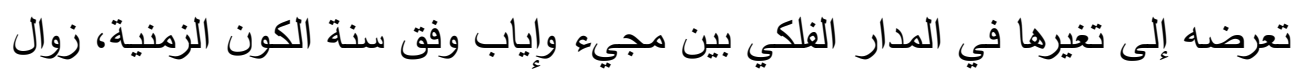

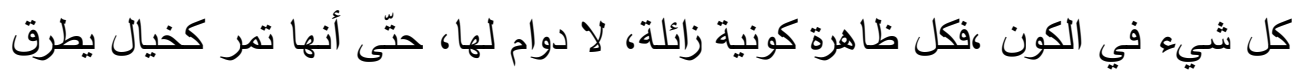

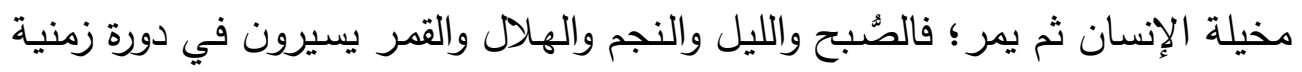

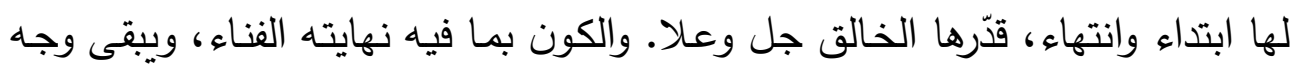

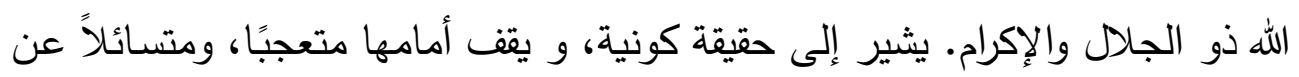
زوال الكائنات (كخيال يشغل الفكر) ثم يمر . 
يستعمل المعري للكواكب والنجوم وهي في حركة أفلاكها، و يشير إلى علاقتها بالزمن من حيث أنها ليس في ثبات بل ظهور وأفول، وهكذا بقية الظواهر الكونية

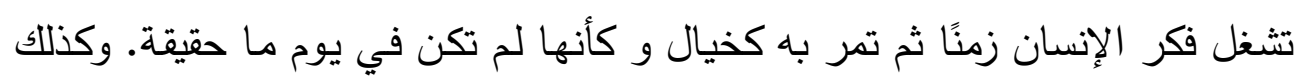

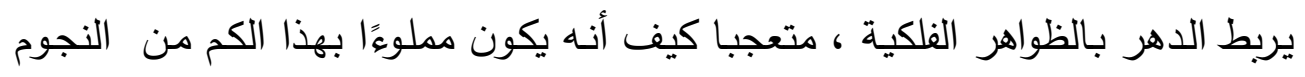

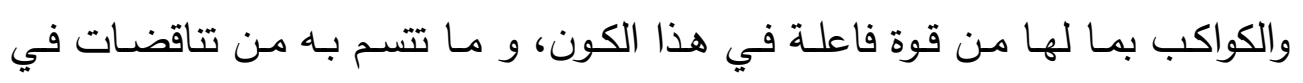

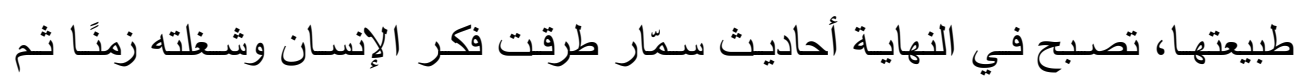

مرت كخيال. يقول:

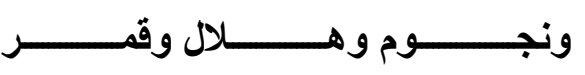
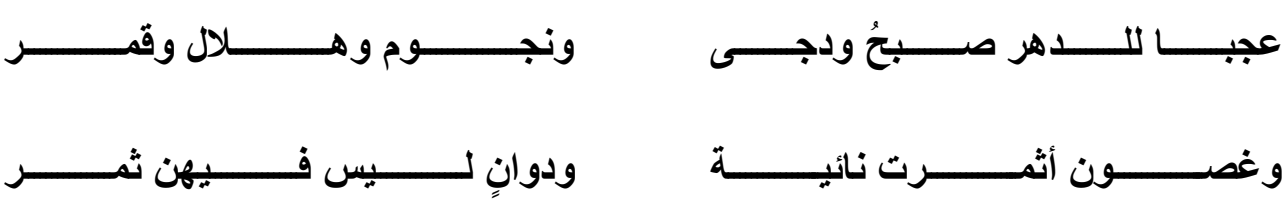

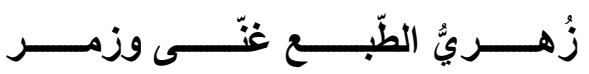

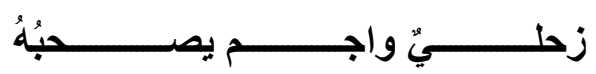

معبـــــــات كأحاديــــــث الستــــــمر

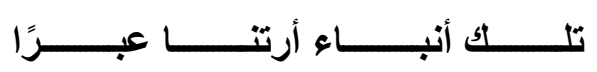

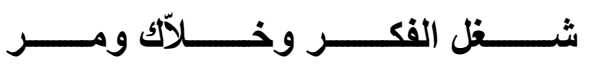

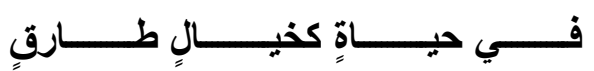

(اللزوميات ج) : (1) - (1)

وقوله عن سنن الله تعالى في كونه، وما في ذللك من حكمٍ تدل على حكمة الخالق و

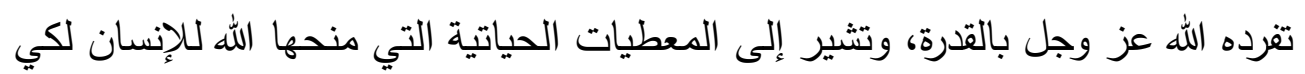

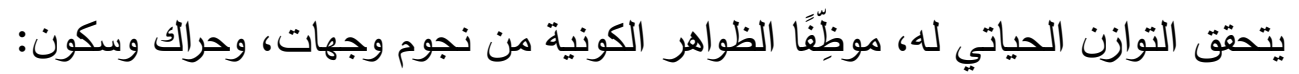

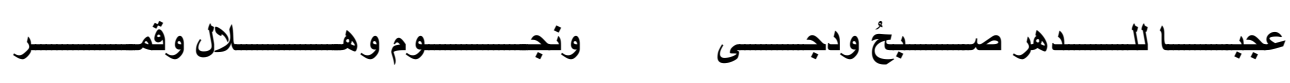




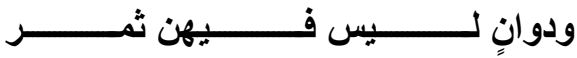

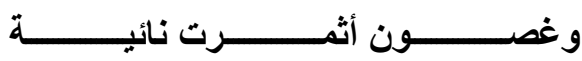

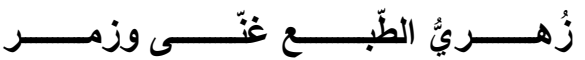

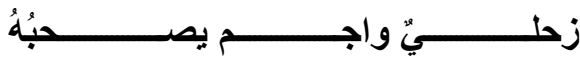

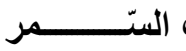

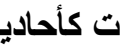

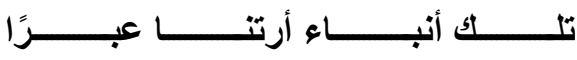

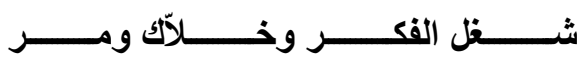

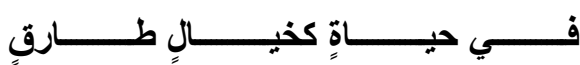

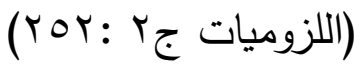

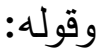

وكــــراه يســــن تـــــارةً و يُحـــرَّك

والمسرع مثـل الحسرف بــين ســهاده

فرضـــــا البريســـة غايـــة لا تـــــرك

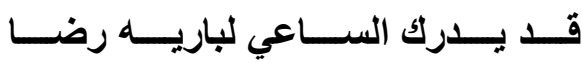

(اللزوميات جr)

يميل المعري إلى التتـاول الذي قد يأخذ الطـابع الفلسفي في علاقـة الطبائع

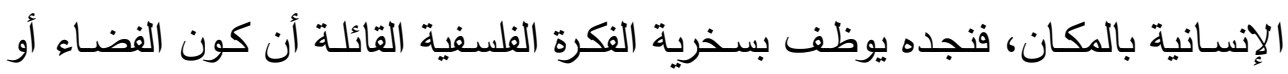

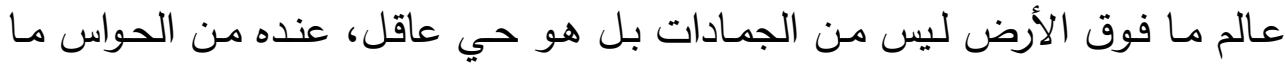
يماثل بـه جنس البشر، منطلقًا مـن هذه الفكرة، يتسـاءل المعري: هل إذا تميَّزت

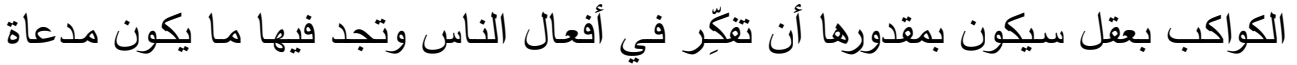

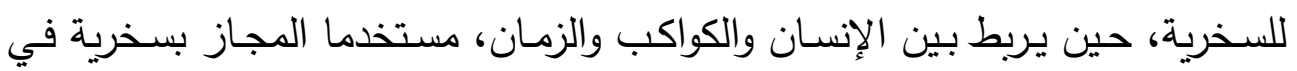
بعض السسائل كالتي تتعلق بالعقلانية مثل قوله الاستفهامي الساخر أيعقل؟، وبوصف

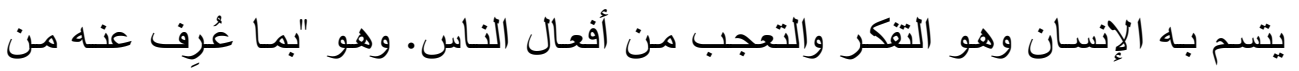

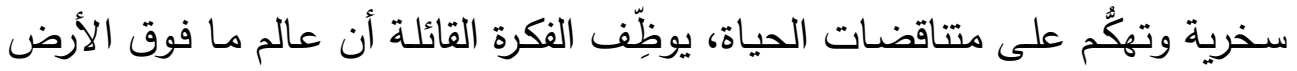

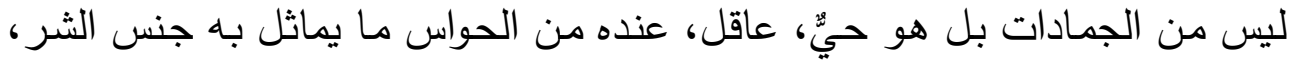


منطلقًا من هذه الفكرة، المعري يتساءل: هل إذا تميَّزت الكواكب بعقل سيكون بمقدورها

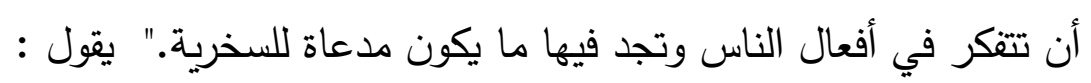

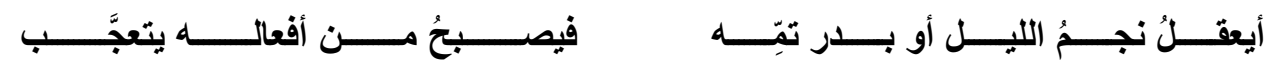

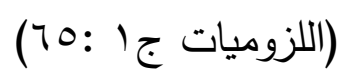

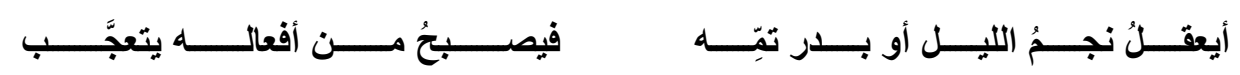

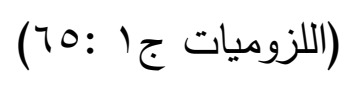

وإذا كانت النجوم تعقل أفعال البشر، وتجد فيها ما يكون مدعاة للسخرية، فبإمكانها

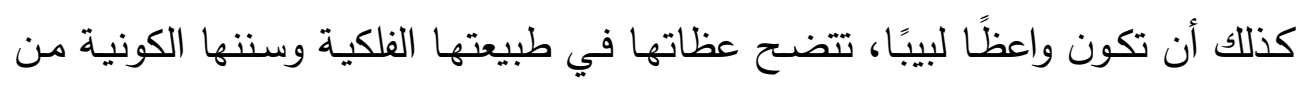
حدوث حركة مستمرة تتتج عنها ولادة وتغيير مواقعها، وأفول. (') وفي هذه السنن عبرة

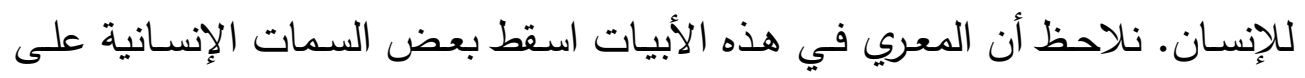

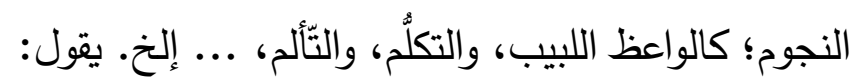

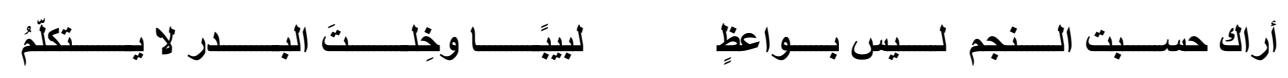

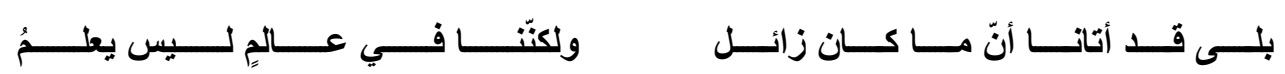

ا (... إن ملاحظة الدوران الظّاهر لبعض النجوم حول القطب استتادا إلى قاعدة رصد ليلة تعود

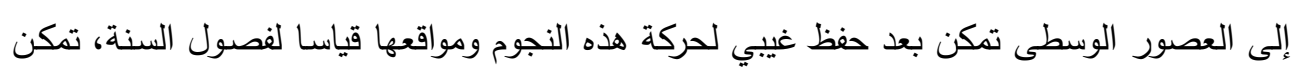

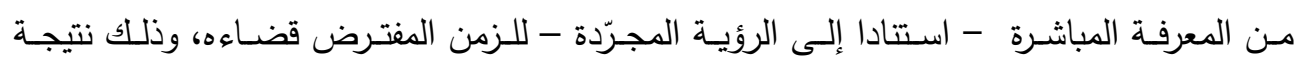

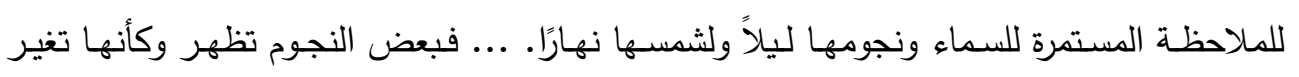

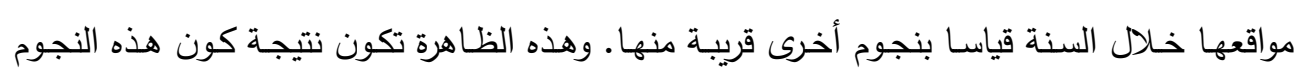

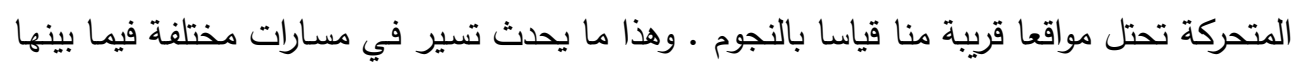

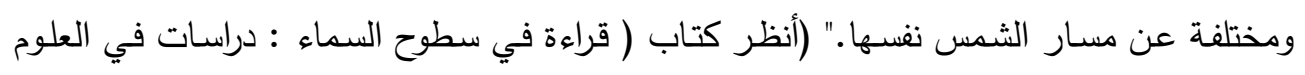
والثقافة الفلكية ،تأليف مجموعـة مـن الباحثين الإيطاليين ترجمـة د ماللك ماللك، المؤسسـة العربية

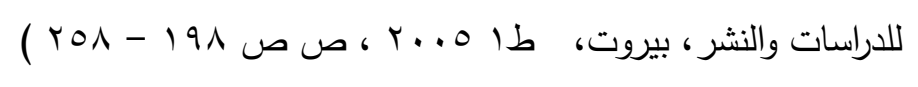


أم اتُّــــــــت كالهضــــــــب لا يتـــــــألم

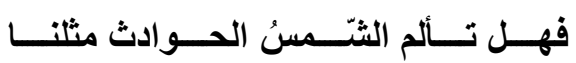

(rV) : (اللزوميات جr)

كما أوجد علاقات في الأبيات التاليـة بين مدلول الألفاظ التي تشير إلى الظواهر الكونية وارتباطها بالزمان في قوله (الصباح) (الثريا) الثرى) (النهار) (الليل) (النجم)

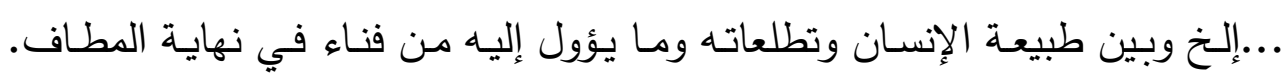
إضـافة إلى مـا تشير إليه الأبيات من مطابقة دلالـة الظاهرة الكونية وواقع الإنسـان

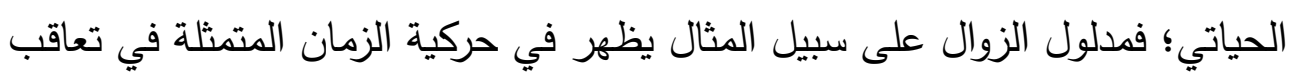
الليل والنهار ، وظهور النجوم وغورها، وهكذا فالإنسان يزول بتعاقب الأزمنة. يقول:

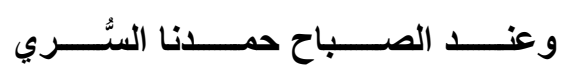

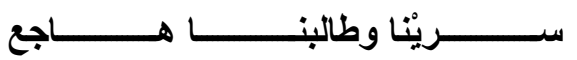

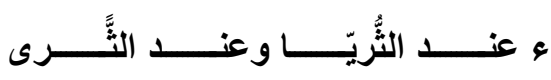

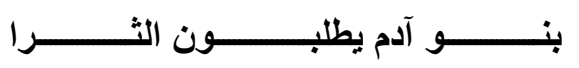

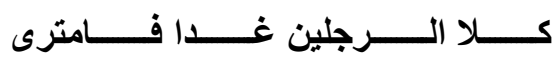

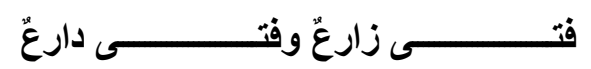

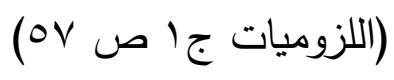

وقوله:

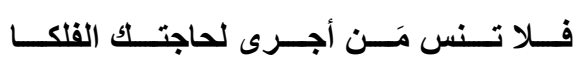

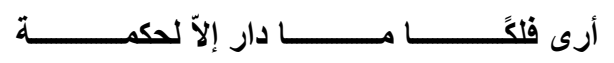

علـــى أمســم لـــم تتـــرك لهــــم ســـاكا

ومـــت حبــال الثــمس مــن قبـلـل عصـــنا

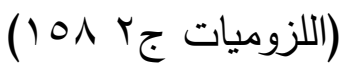

لإية

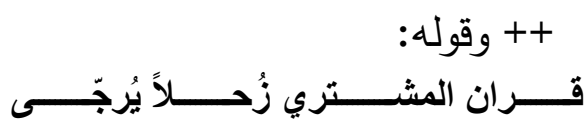

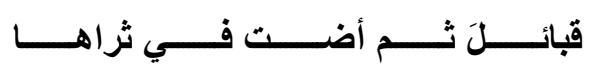

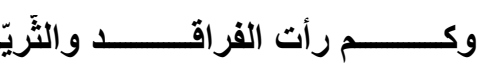


(اللزوميات جr: ( צr)

لم يترك المعري من آيات الله في الكون؛ من أرض و ما تحويه من جبال وبحار وأنهار ، وسماء وما فيها من كواكب وأنجم ومجرات، إلاّ وأمعن النظر فيها مستتبطا العلاقة التي تربطها بالإنسان. لــو تيقول: لــــم الأرض مـــا أفعــال ســاكنها

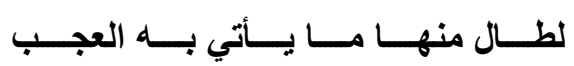

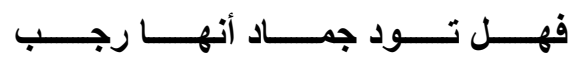
بـــــ الســــادة أن لــــم تُخــــق امــــرأة

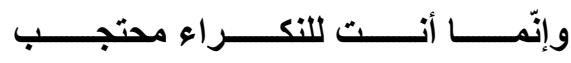
ومــا احجبــتَ عـن الأقــوام مـن نســــ

فقلــت صـــبرا وتســليما كـــا يجــب

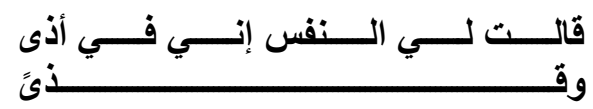

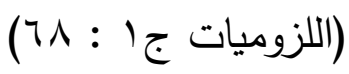

وقوله:

وأي التّــــاس لـــيس لــــهـ عيـــوب

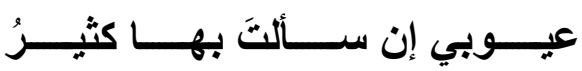
ولـيس عليــه مـــا تخفــى العيـوب

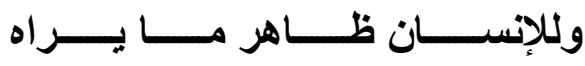

وقـــ مُلئسـت مــن الغــش الجيــوب يجــرُون الـــنيولَ علـــى المخـــازي

إذا وهَــــتِ المخالــــب والنيـــــوب

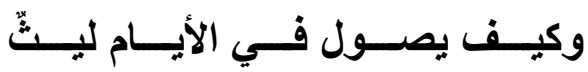

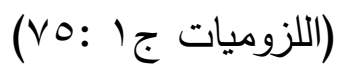

هذا هو الإنسان في نظر المعري مليء بالعيوب، لكنه برؤيته الحكيمة يدرك أنه لا

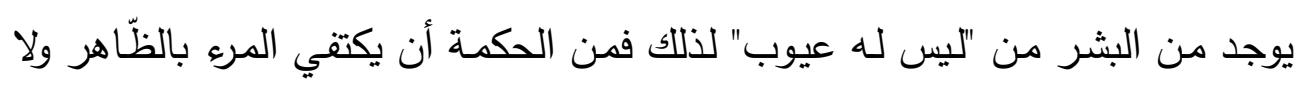


يبحث على مـا خفي من العيوب. لكنه يعود إلى إظهار حقيقـة من حقائق النـاس المتغطرسين وهم يجرون ذيولهم على المخازي، ومـا اتّسمت بـه أخلاقهم من غش ونهب ملئوا به جيوبهم، وكيف تتوافق غطرستهم مع تلك المخازي، ضـاربا لذلك مثلاً عن الليث الذي ضعفت مخالبه وأنيابه، فليس بإمكانه أن يصول بقوته. أمّا ما يشير إلى رؤيته عن المجتمع، فقد تمثلت في نقده الـلاذع حيث يصف فيه أخلاق الناس وطباعهم التي جُبلوا عليها والتي تجرهم إلى الغي والغدر، لذلك فالجماد أبر لله من الإنسان، لذا فهو ينصح بهجر الناس لما اتسموا به من غدر .

يقول:

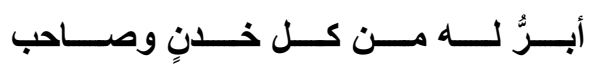

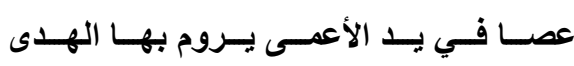

يسـيرون فــي نهــجِ مسن الغــدر لاحسب فأوســــع بنــــي حـــواء هجـــرا فــإنهم لــــى الحشـــر إلاّ كــلـل أســـودَ شــــاحب

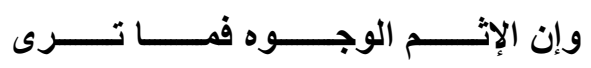

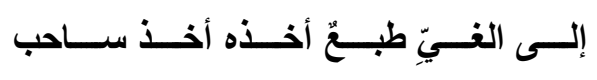

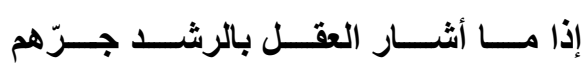
(اللزوميات ج) (1) (1) (1) (1)

وهو في كلامسه عن الطبائع، يشير إلى الغرائز منها التي أصبحت من الصسب التخلص منها، حتى أن جبلت النفوس على أن تألفها، وهو مما يسبب تفاقم المصائب والرزايا. ومن الغربب أننا نجد المعري مشاركًا بالغريزة في أمور نهاه عقله عن فعلها لكن طبعه بفعل الغريزة جذبه إليها، فهو مثل بقيـة الناس الذين كان يذم طبائعهم، تجذبه غريزته إلى فعل بعض الأمور التي لا يقبلها عقله. وقوله:

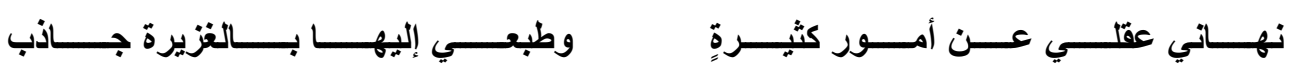

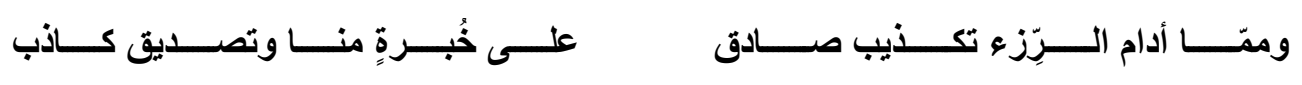


(اللزوميات ج) (1) (1) (1)

لذلك هو يؤكد أن الطبع شيء ملازم للإنسان منذ خلق، أما ما اعتاد عليه المرو فهو يُعد طبع ثاني قد يكتسبه من واقع الحياة ومن يختلط بهم من أنماط البشر . يقول:

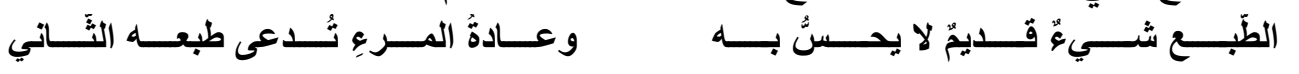

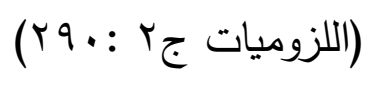

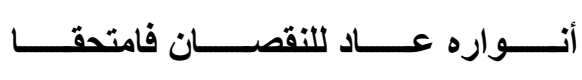

وقوله:

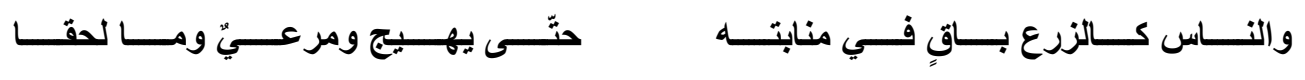

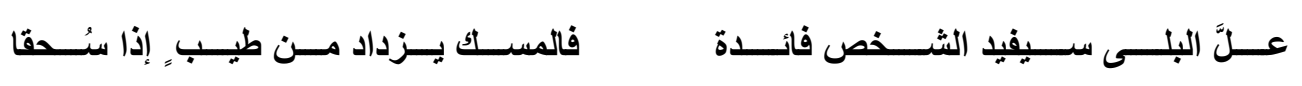

(اللزوميات جr : (ا) (1)

وفي الأبيات التالية دلالات لأبجديات المعرفة عن الطبائع الإنسانية وما فيها من أوجه ذات علاقة بالظواهر الكونية كما يراها المعري، وهي معبرة عن فكر هذا الثاعر لإليات ورؤيته تجاه الإنسان والكون المحيط به. يقول:

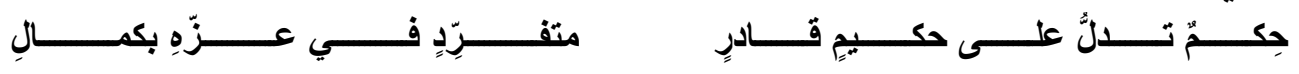

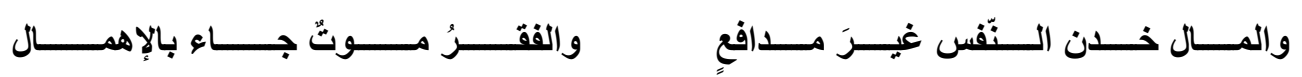

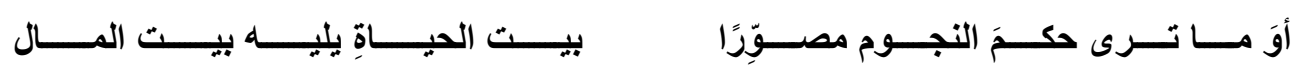

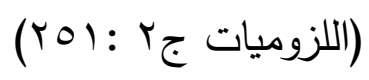

ويقول:

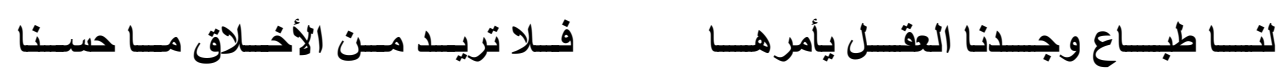




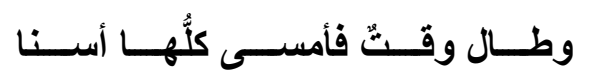

نحـن الميـاه أقامــت فـــي مواطنهـ

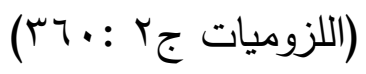

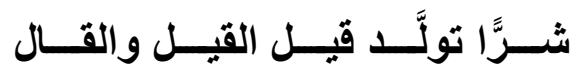

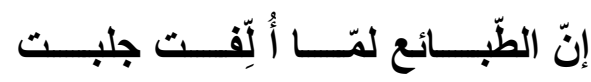

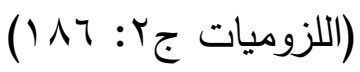

يقول في أفعال الناس و تعجب الزمان منها حيث يبدو كذبهم سافر بما يفعلونه من

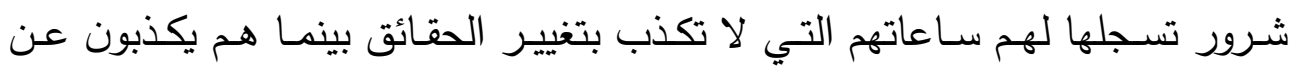

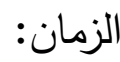

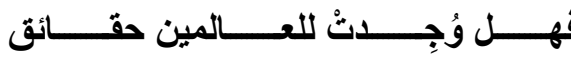

أرى النساس شــرًا مسن زمســان حـواهم

رمـــــــــــت ســـــاعاتهم والـــــقائق

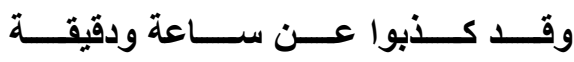

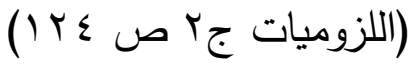

أمّـا فيمـا يتعلق بالسيرورة الكونيـة وحقائقها؛ فـالأفلاك في الكون تدور دورتها

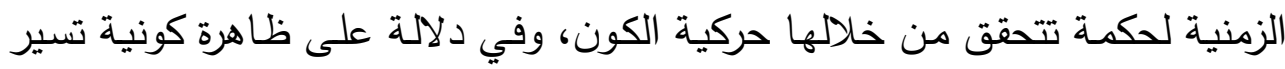

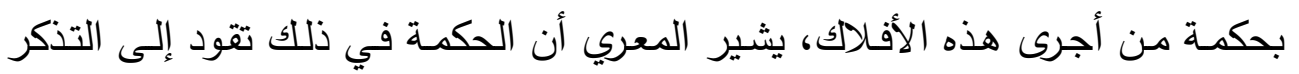

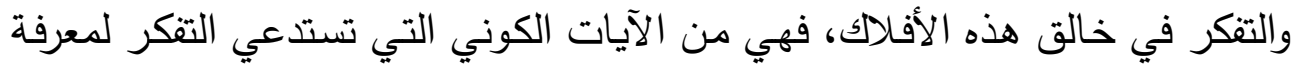

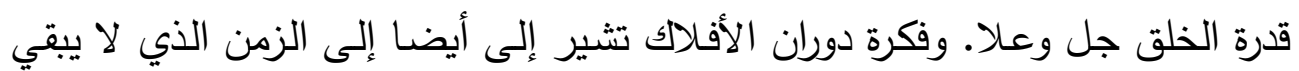

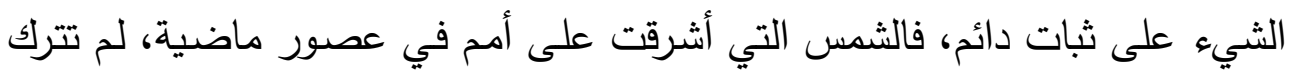

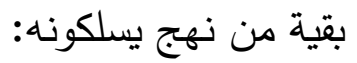

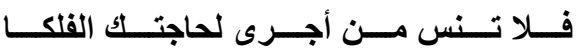

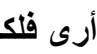


Lا

ومسدَت حبــال الثـــس مسن قبـل عصسرنا

(اللزوميات جن (الزي)

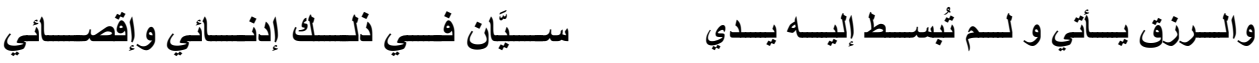

لو أنه في الثريا والسِّكك أو الثِّعري العبور أو الثِّعري الغميصاء(' )

(اللزوميات ج) (0) ص(0)

: يقول :

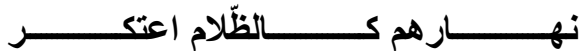

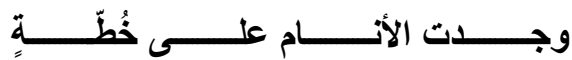

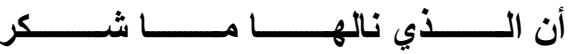

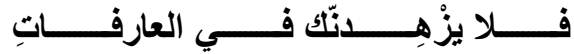

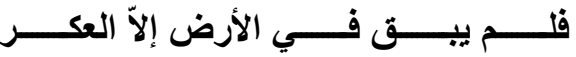

وقــــ شـــرب الـــــر صــفو الأنـــام

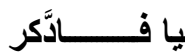

ناس

خلت

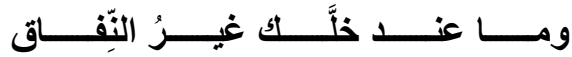

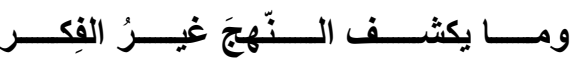

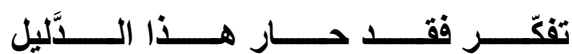

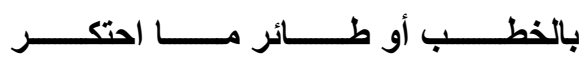

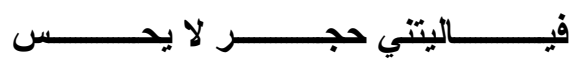

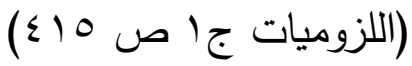

ا الثعري:كوكب نيّرُ يقال لهه المِرزم يطلع بعد الجوزاء، وطلوعه في شدّة الحر ؛تقول العرب: إذا الثِِّعرى جعل صـاحب النحل يرى. وهما الثِِّعريان: العَبُور التي في الجوزاء، والغميصـاء التي في

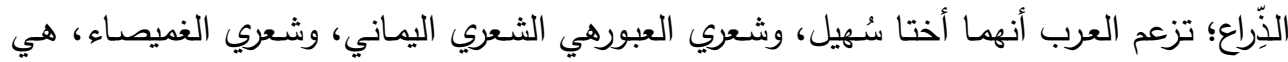

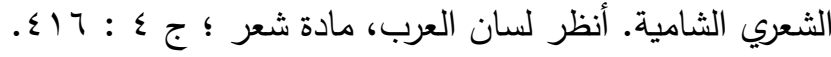


المعري بسبب فقده البصر يعيش في ظلام، وقد وظف مدلول الظلام كظاهرة

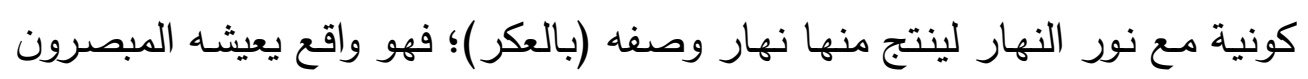

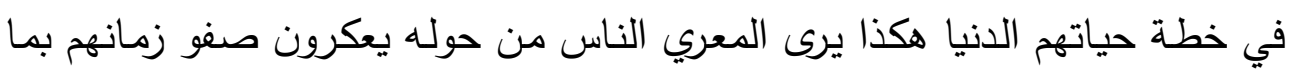

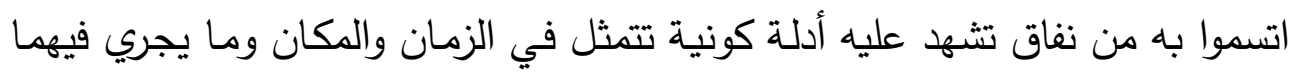

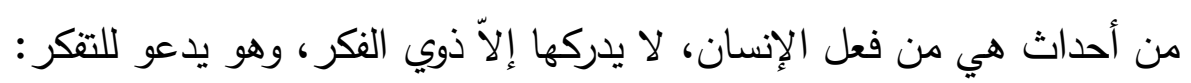

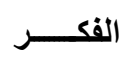
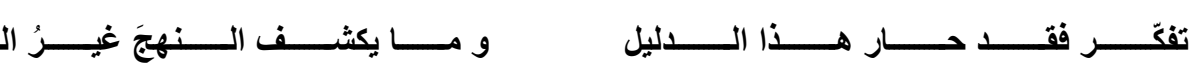

لكن المعري يشعر باليأس من الناس، فيتمنى لو كان حجرًا لا يحس بما يحيط به ألها.

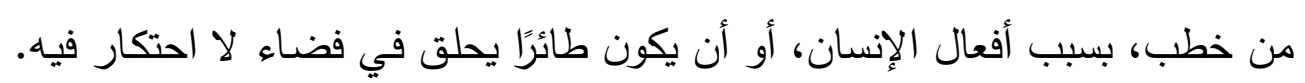

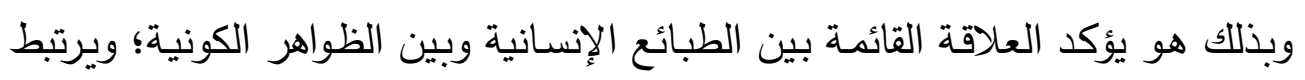

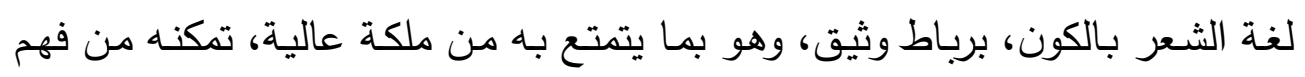

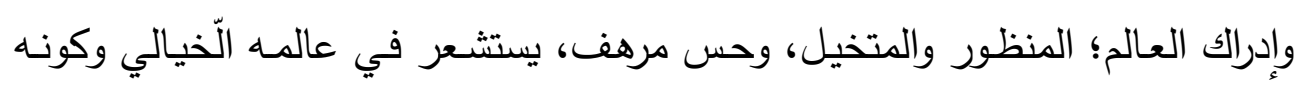

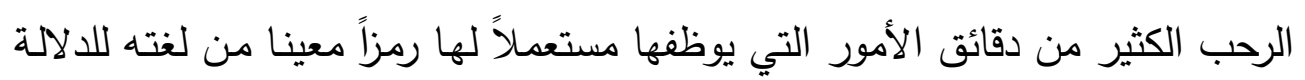
علي غايته.

هذا التمازج بين اللغة والمعرفة الكونية، يعود إلى ما تتسم به اللغة الثعرية من

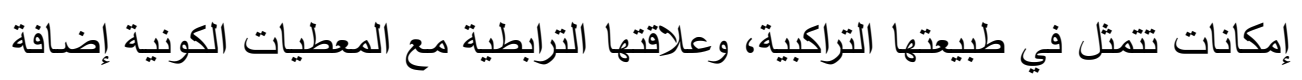

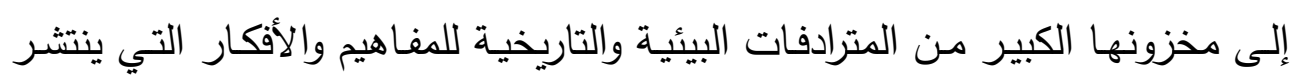

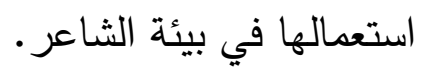

لذلك فاللغة تحمل في تراكيبها الصوتية وصفا للموجودات في الكون، وإيجاد

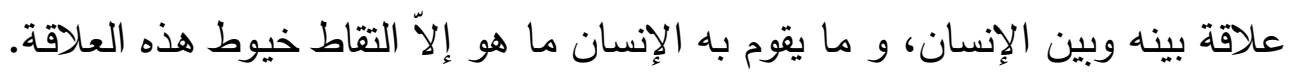

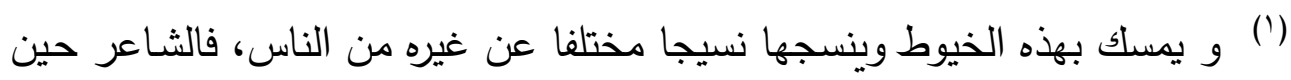

ا قد يشترك الثاعر الفرنسي مالارميه Mallarme مع المعري في إيجاد علاقة بين الأشياء في

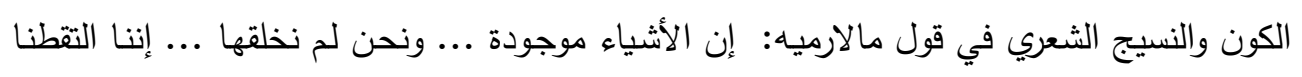


يستخدم اللغة لأغراضه الخاصة، يشكل من الكلمات جوقة موسيقية لها جمالياتها التي تسـهم في إيجـاد تتـاغم بـين الكلمـات و الأشـياء في هـذا الكـون فيحصـل التــاغم والانسـام بـين النسيج الثـعري ومعـاني الأشـياء في الكـون. "ذلك أن كل خطـاب إنساني، باللغة الطبيعية، حمّال أوجه بدرجة من الدّرجات؛ والشعر حمّال أوجه ومعان لأن جـوهره المجـاز والاسـتعارة والكنايـة. كمـا أن جـوهر الثـعر الصـادق هـو الحــم والرؤيا. وقراءتتا للشعر تتأسس على هذه المسلمة؛ و من ثمّة فإنها متعددة، لكنها متواصلة متواشجة تواصل مفردات اللغة وتواشجها. ذلك أن اللغة عبارة عن نوى قليلة العدد لكنها تتـامى بأنواع الاشتقاق وضـروب الاشتراك والترادف، وتتلاحم بالتركيب وبالتوليف. إن اللُّة الطبيعية، مفردات وتراكيب، محكومة بالنسبة وبالتتاسب، وبدون نسبة فإنه لا يمكن أن يربط بين مفردات اللغة، ويحصل التواصل والفهم والفعل ورد الفعل. في إطار صدور الكثرة من الوحدة والمتعددة من الواحد، فإننا نفترض أن هنالك سرياناً رابطا بين جزئيات الكون، ومنـه جزئية اللغـة. ذلك أنـه إذا كان هنـاك تتاغم للكون وانتظام لله، فإن كون النص الشعري متتاغم ومنتظم؛ إن النص كون صغير صادر عن شاعر هو نسخة الأكوان".

( حمح مفتاح رؤيا التماثل صن )

حين تساعد اللغة على فهم الأشياء والموجودات، لما بينها وبين الظواهر الكونية مـن تطـابق، تؤكِدِ القـوة الترابطيـة بـين الإنسـان والكـون، مثلمـا تؤكد إمكاناتهـا في استيعاب المعطيات الكونيـة والحياتيـة، ومن ثم وصف الكون والحياة الإنسـانية بكل المنعطفات. فهناك علاقة تبادلية بين اللغة وبين البنية التي يقوم عليها الوجود. (')

فقط خيوط العلاقات بينها ... وهذه الخيوط هي التي تتسج الثعر وتشكل جوقته الموسيقية (جون

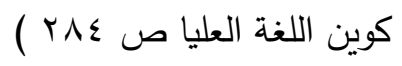
| الألفاظ في اللغة مجرّد رد فعل على فعل الواقع فإن العلاقة بينها وبين الواقع هي العلاقة نفسها بين الفعل ورد الفعل، ولهذا فإنه يمكن النظر إلى هذه العلاقة على أنها علاقة ذات لعات لسانين: لسان

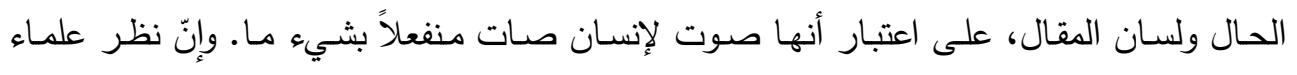


واللغـة الثـعرية وإن ترتكز في صناعتها على الخيال، إلاّ أنها في جوهرهـا ترتبط

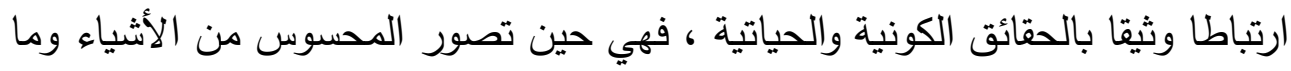

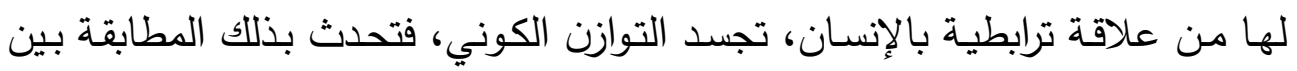

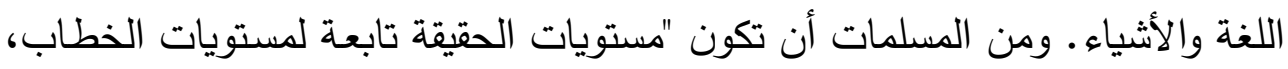

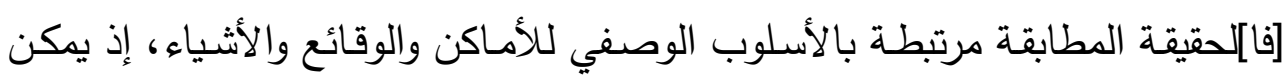

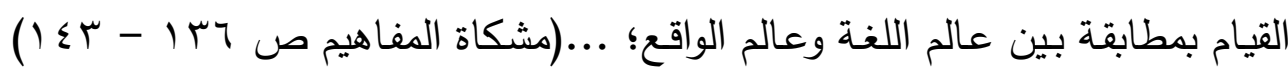

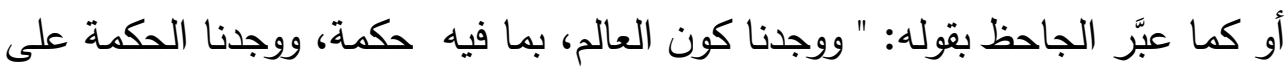

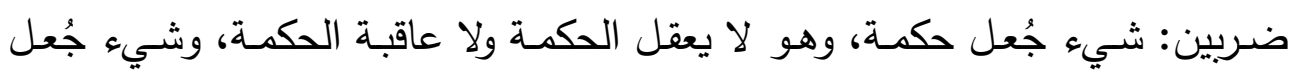

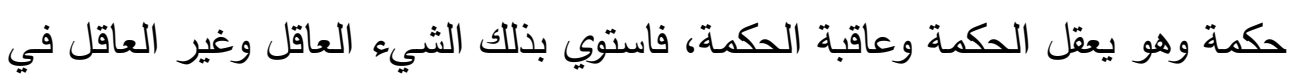

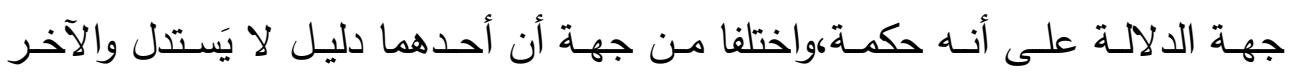

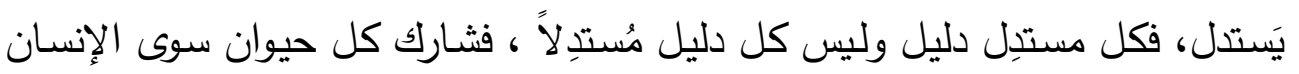

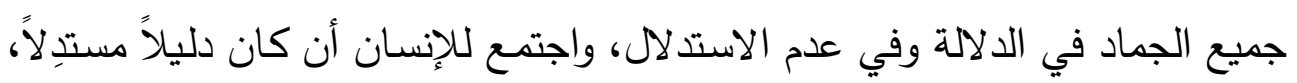

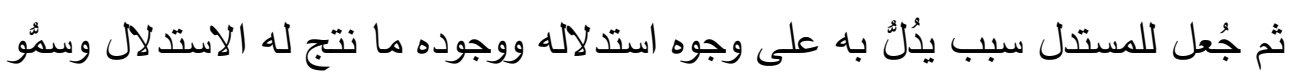

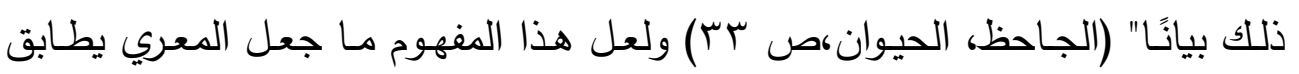

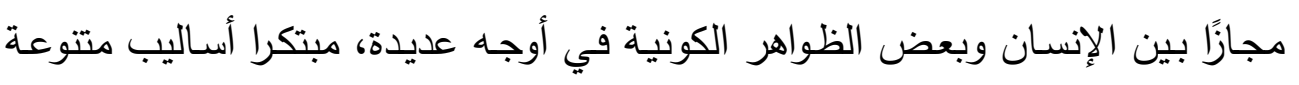

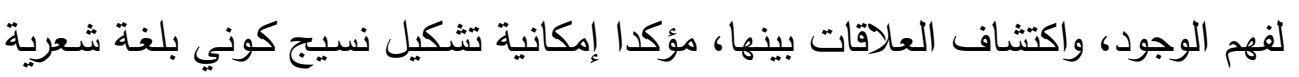

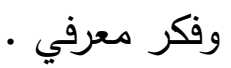

\section{الزمان كظاهرة كونية في شعر المعر :}

.يشير المعري إلى الزمـان على أنه " ... شيء أقل جزء منه يشتمل على جميع.

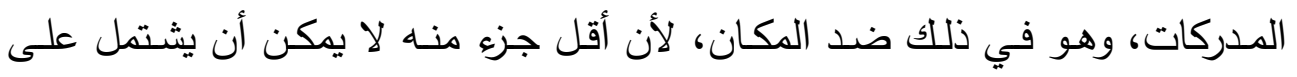

الألسنية إلى اللغة - أي لغة - على أنها مجرّد وسيلة للتفاهم قد أبعدنا عن أن نتعامل معها تعاملاً

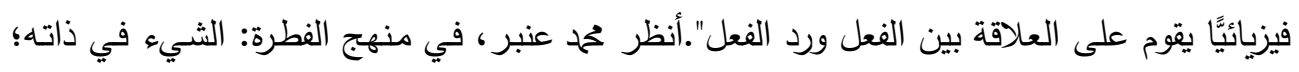

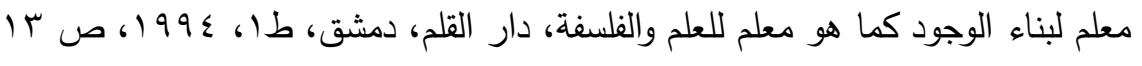


شيء كما تشتمل عليه الظروف، فأما الكون فلا بد من تشبثه بما قل أو كثر" (رسالة

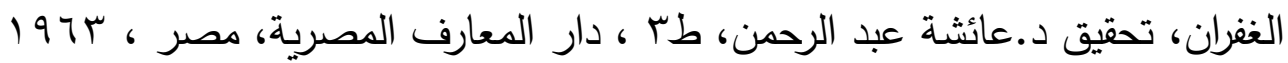
، ص بrع) ويشبه الزمان بآنية تحوي الحوادث، فيقول:

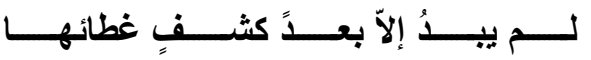

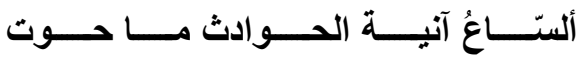

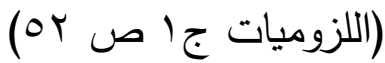

اختلف المفكرون والفلاسفة في تعريف الزمان، (') حيث عرّفه بعضهم أنه حركة

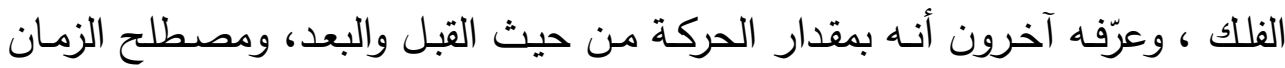

ا الزمان في اللغة: جاء في" لسان العرب " أن الزمن والزمان اسم لقليل الوقت و كثيره، و (أزمن

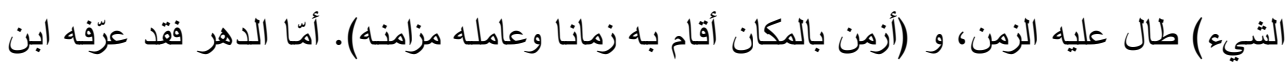

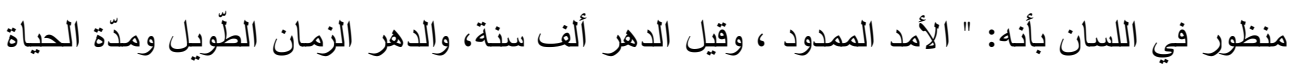

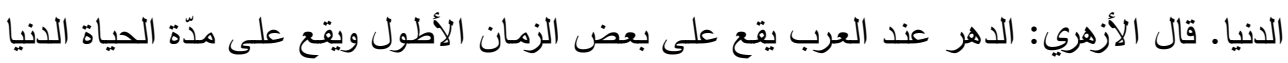

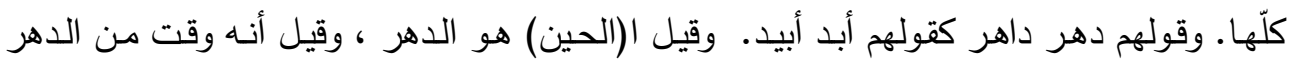

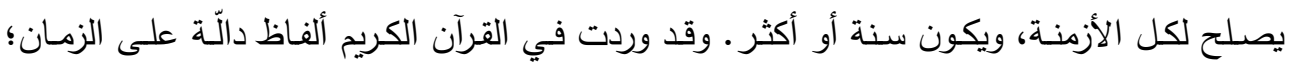

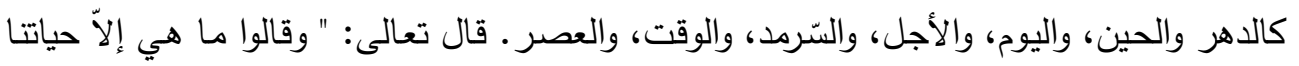

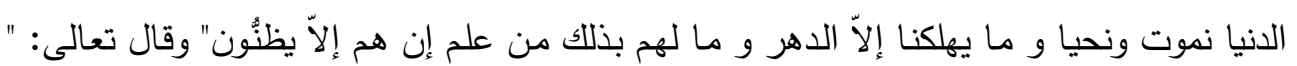

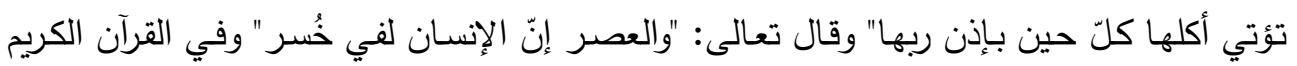

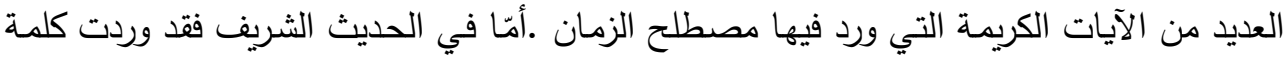

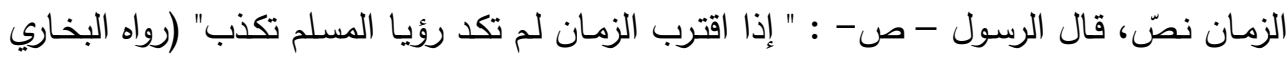

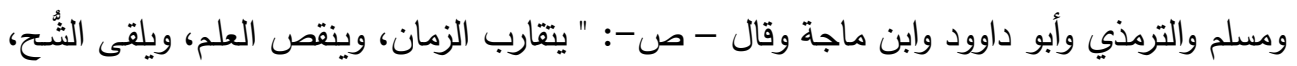

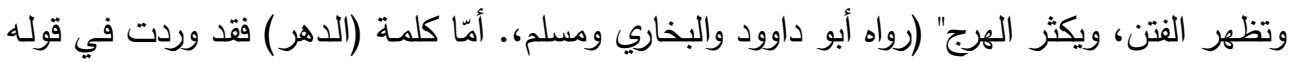

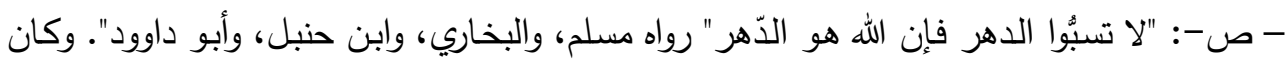

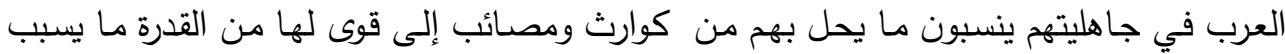

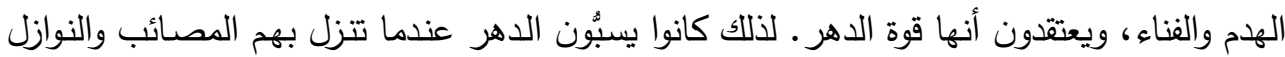

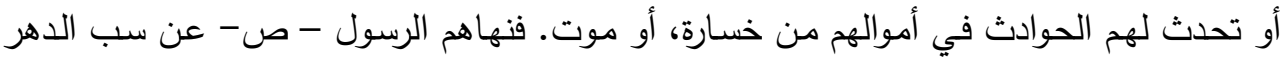
بسبب الحوادث لأن الله عز وجل هو الذي ينزل الحوادث ويقدرها، أمّا الدهر أي (الزمان) فلا فعل الده 
ودلالاته الفلسفية؛ كما يقول الجرجاني: "هو مقدار حركة الفلك عند الحكماء، أمسا عند

له لأنه مخلوق من مخلوقات الله تعالى. أمّا الفلاسفة فقد ميزوا الزمان بمعانٍ أربعة: "التصوري: وهو

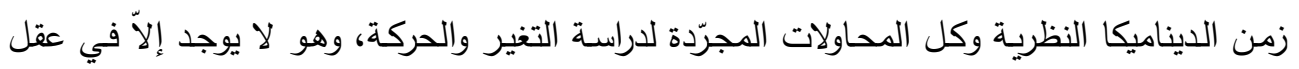

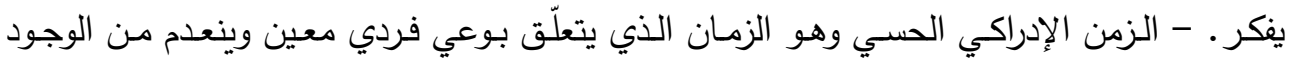

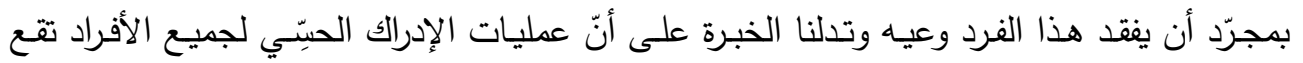

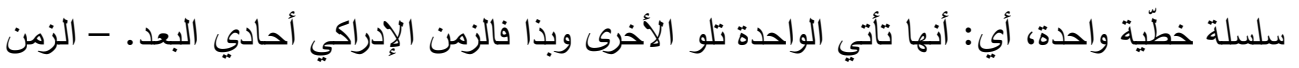

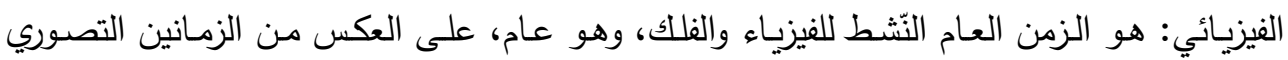

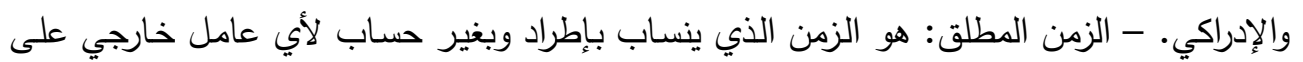
امتداد الكون.: عند ابن سينا، ففهوم الزمان يرتبط بالحركة، و يتتاول في " تحليله العميق لفكرة الزمان مواضع

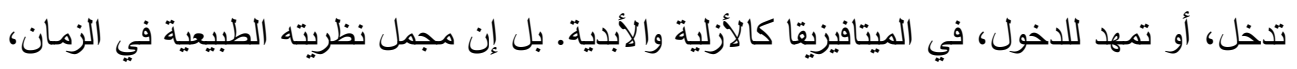

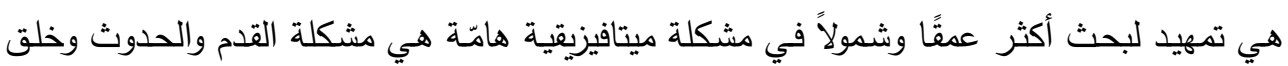

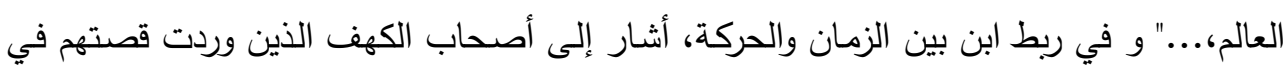

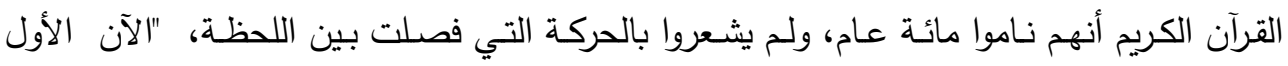

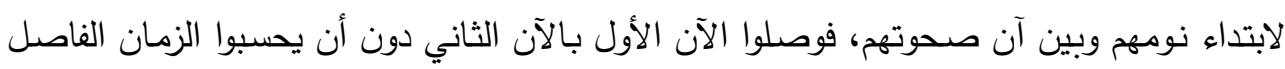

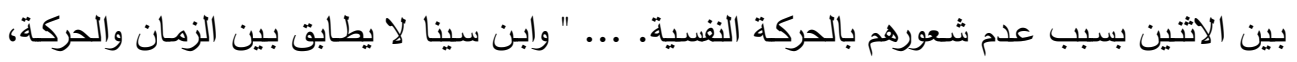

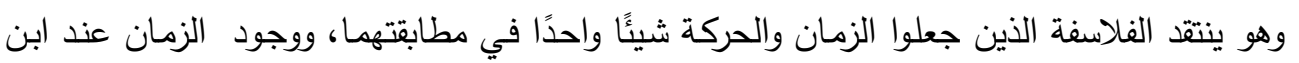
سينا يثبت من خلال (الحركة، والسكون، والمتحرك والمسافة) ويرى أن بالإمكان أن ييتدئ متحركان المان

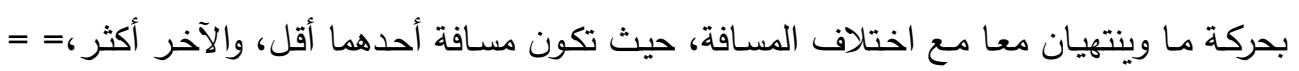
يقول: " إمّا لاختلاف السُرعة والبطه، وإمّا لتفاوت عدد السكونات المتخلّلة. ويجوز أن يبتدئ اثنان

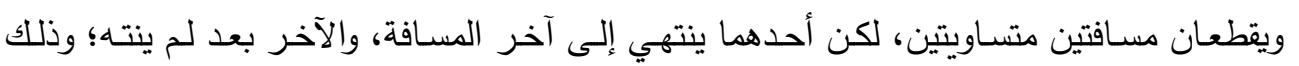

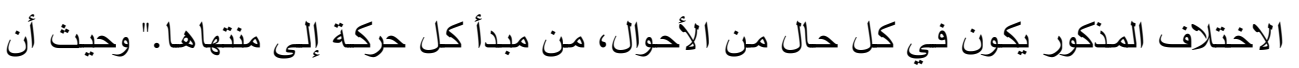

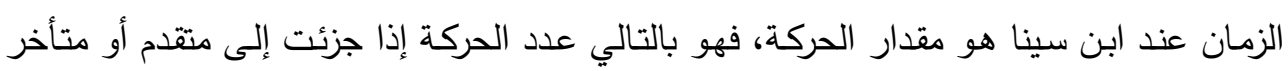

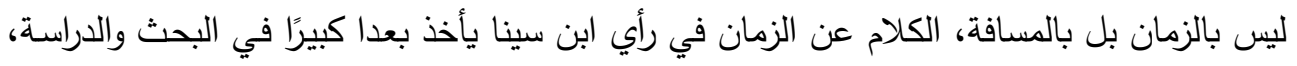

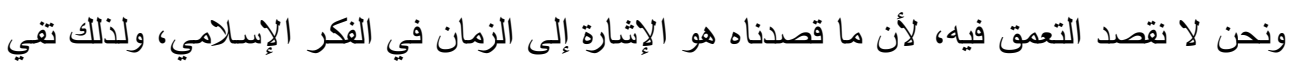

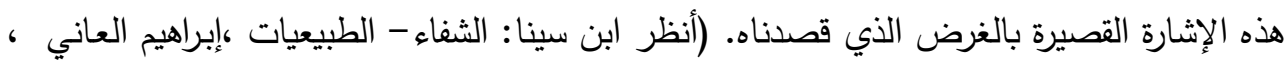

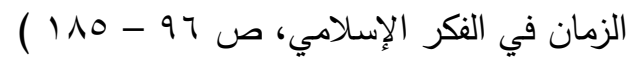


المتكلمين فهو عبارة عن متجدد معلوم يقدّر به متجدد آخر موهوم. كما يُقال آتيك

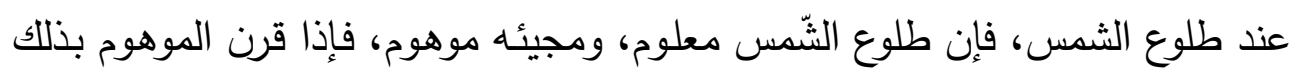

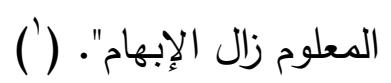

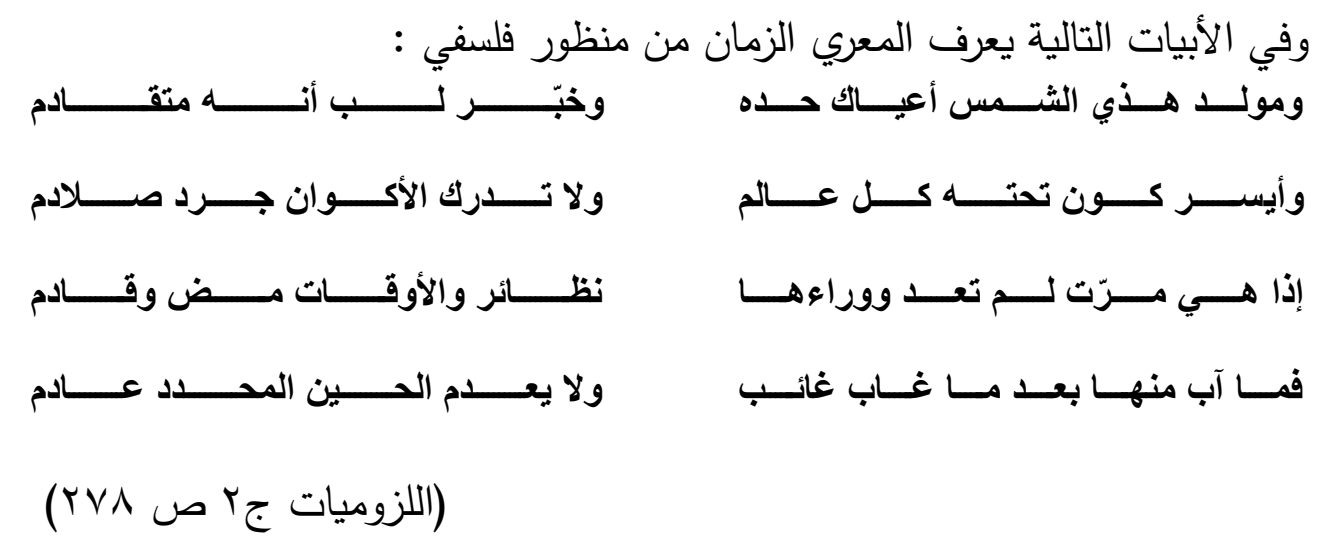
يلاحظ من هذه الأبيات ألبعد الفلسفي في تعريف المعري للزمان. فأقل جزء في الزمان "يشتمل على جميع المدركات. .... فإن أصغر جزء من الزمان - وليكن ثانية أو لحظة - يمكن أن تختزن فيه كافة المدركات العقلية، ( طفولة ، شباب ، حياة، فناء، ظواهر ، طبيعة إلخ" (إبراهيم العاتي، الزمان في الفكر الإسلامي ص (؛ () ) حركة الزمان عند المعري تسير وفق حركة متتالية سريعة سرعة الخيول، بل أكثر من ذلك فالدهر هنا يشبه البرق في وميضه. فالزمان تتلاحق أجزاؤه (دهر) تشكِّل كلاًّ يملأ الكون؛ فالكون يؤلف من السنين والشهور والأيام.:

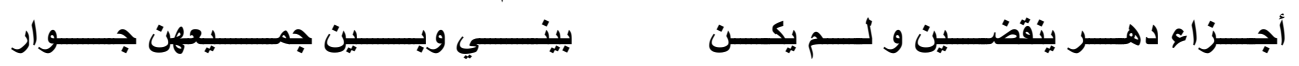

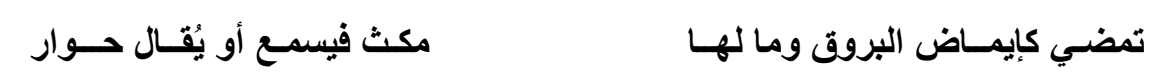

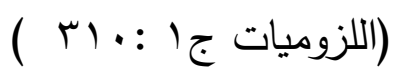

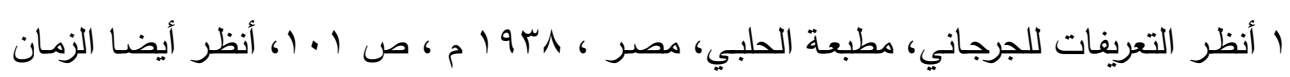
في الفكر الإسلامي ص الفربعات 


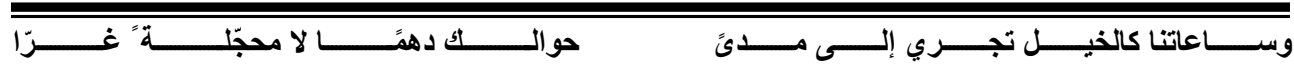

(اللزوميات ج ا : • (بr)

يقول المعري مشيرًا إلى أن الدهر يحوي أزمنة يتلاحق أولها بآخرها ويكون (آخرها

نظير الأول)

الأول

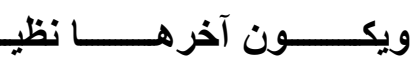

و يقول:

حتّـــى يُعـــدَ مـــن الزّمــــان الأطــــول

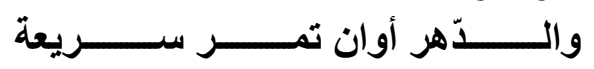

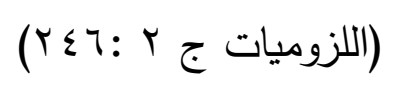

ومن الملاحظ أن نظرة المعري إلى الدهر تلتقي مـع فكر الجاهليين عن الدهر حيث يستبطن الزمن قوة خفية قادرة على تدمير الموجودات في الكون، فتحيلها إلى عدم، وتلحق بالإنسـان الشرور والنكبات وصنوفا من ألوان المصـائب. لذلك كان المعري دائما يربط الشرور ارتباطا وثيقا بالدهر، فهو في رأيه كأنه ذلك المحارب الذي يوجه سـهامه ليفتلك بـالآخرين دون أن يخطـئ في تصـويبها، أو كأنـه فـارس يـأتي مبشـرا

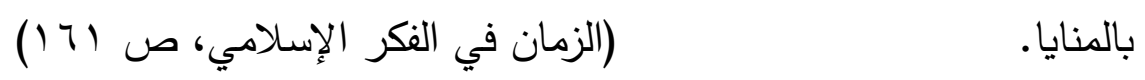

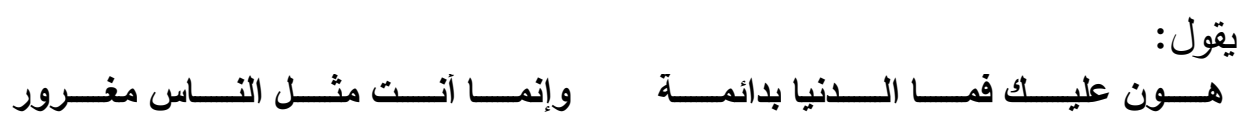

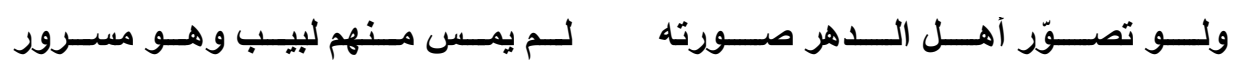

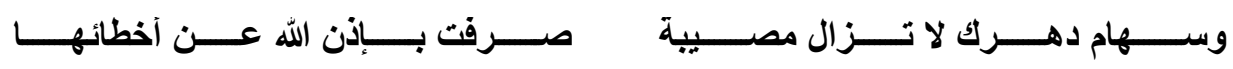

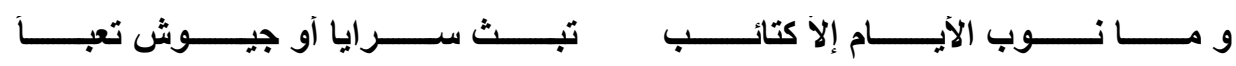

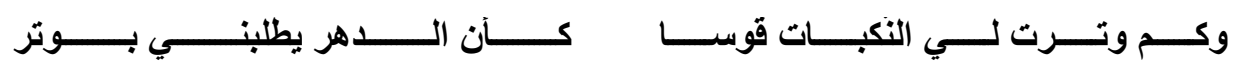

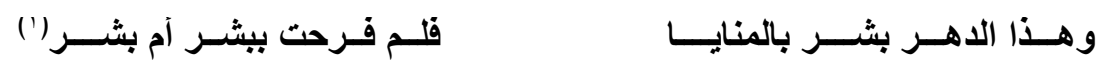
ا اللزوميات: ج) ص Or 
أكثر مـا يهتم بـه المعري في مسـالة الزمـان، هـو التّعاقب والتّوالي؛ تعاقب الليـل والنهار، توالي الماضي والمستقبل، حيث أشار إلى التعاقب إشـارات عديدة في صور

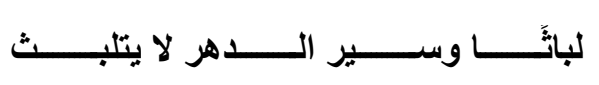
مختلفة:

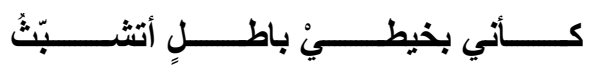

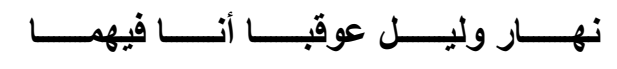

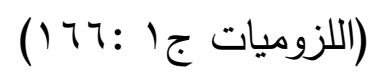

ليســــت كمـــــا اعتــــاد الرّكائســـبـ تبــــرك

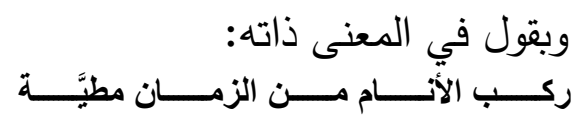
(اللزوميات جr) (107)

وليــــا بتــرب الأرض يلهـــو ويعبــث

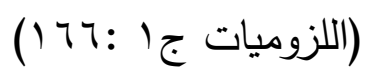

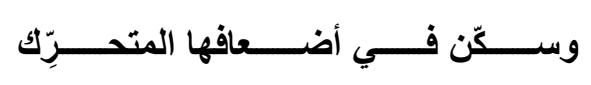
وقوله: (اللزوميات جr : ( النr )

كثيرا ما يشير إلى الزمان، كمسألة من مسائل علم الفلك، حيث يربط بين الزمان والنجوم في التغيير الذي يـلام الحركة في الظهور والاختفاء مثلما هو حال النجوم والكواكب وهي في حركة الظهور والاختفاء. وهو في هذا الربط بين النجوم والزمان، يثير إلى سنن الله عز وجل في الكون من حيث حركة الأجسام السماوية، والعلاقة وهرية 
التي توجد بين الزمان والظواهر الكونية، علاقة علمية فلكية تدمج بين الزمان وحركة

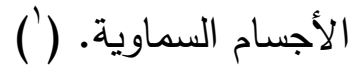
يقول:

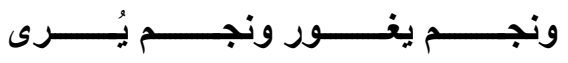

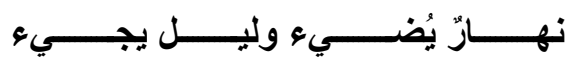
( ov: اللزوميات ج) ويقول:

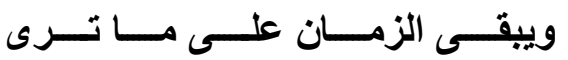

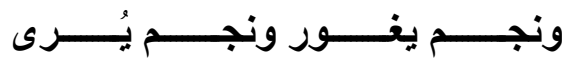
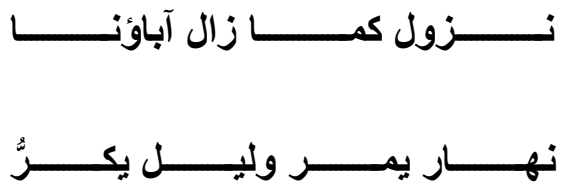

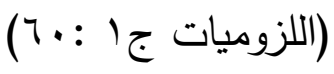

والزمان عند المعري ينقسم إلى سنين وشهور وأيام وساعات ودقائق، والأيام هي الأمس واليوم والغد تسير وفق نظام إلهي في دقّة متتاهية. فالأمس واليوم ولغد هي الماضـي والحاضر والمستقبل. الماضـي يندثر ، والمستقبل مجهول لأنـه لـ يأتي بعد

ا... الكون يخضـع للتغير ، والوقت يتمثّل بظـاهرة التغير التي تربط بين النموذج الثّابت والكون

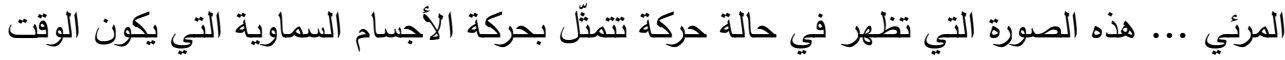
فيها نتيجة تفاعلها، لهذا فإن الوقت والكون يكونان متلازمين في وجودهما طالها يكون الأول صفة

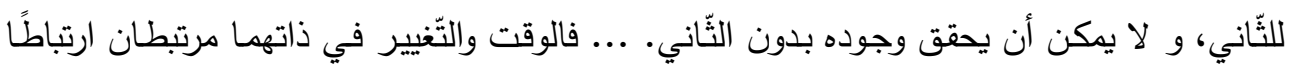

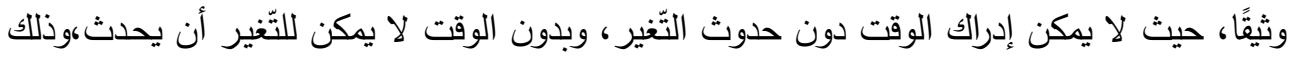

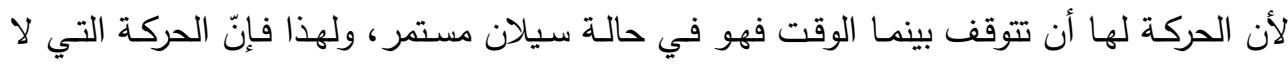

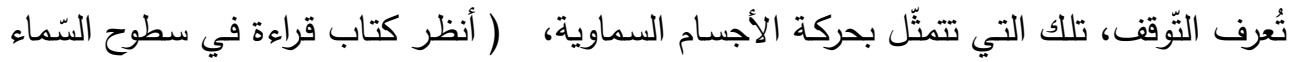

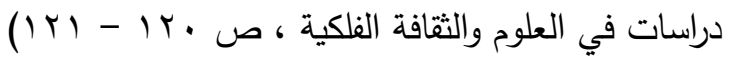


فهو غير معروف، ولا يتبقّى غير الحاضر؛ الذي هو (الآن) لكن المعري يتردد أيضًا في تحديد مصير الزمن الحاضر ، لأنه سيندثر مع بقية أقسام الزمان • يقول:

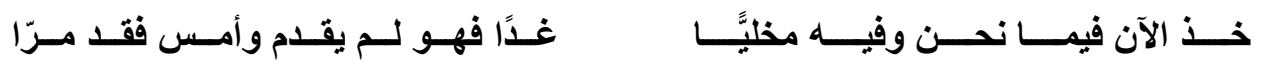

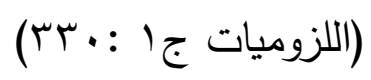

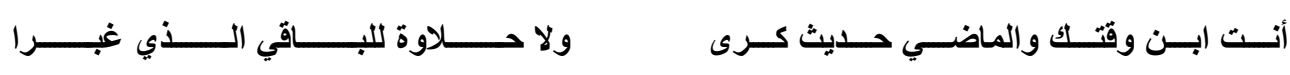

(اللزوميات ج ا) (rrv)

معروف عن المعري نظرته الساخرة بواقع الإنسان وما آلت إليه حالته في واقعه الإنساني،حتّى أصبح مضحكة للزمان. ولكي يحقق هذه الصورة الهزلية للإنسان، منح الزمان إنسانية تتمثّل في صفة الضحك والقوة المحِّمسة ، في حين شخّص الإنسان في سمة الجماد الهش الذي يتهشم ولا يمكن إصـلاحه فالإنسان هنا كالزجاج المهشم

وحُــــقَّ لســــــان البســــــــة أن يبكـــــوا

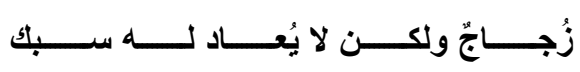

(اللزوميات جr) (101) (ل1)

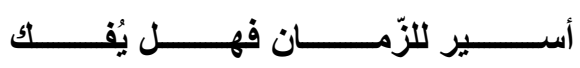

(اللزوميات جr) (107)

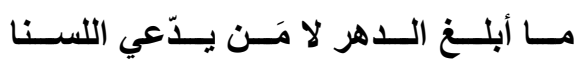

ســـارت وأســـرت فــلا أينــــــا ولاوســنـا

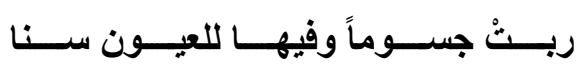

(اللزوميات جrص. • (r)

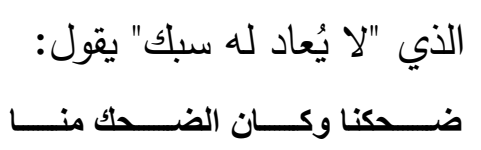

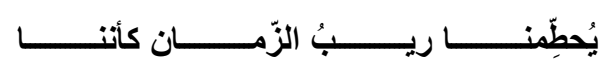
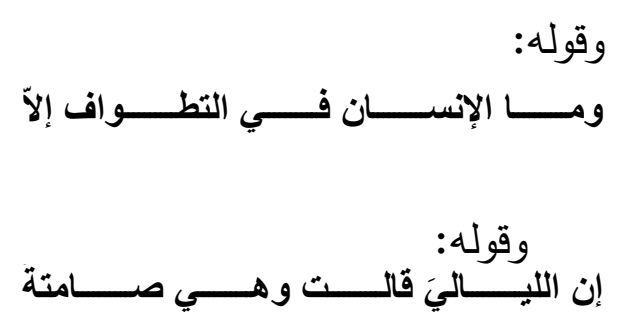

ســـــان خــالق هــــي الثُّـــــب دائبـــة

والثـــمس تغــــر أهـــل الأرض مصـــلحة 
فـــنهن بــيضن فـــي العيــون وســـودُ

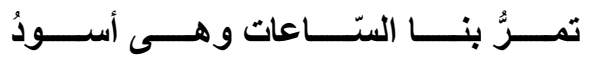

وينبـــهـ مــن بعـــ النُهـــى فيســـودُ

فحســـبك عــــرًا أن يُقـــــال حســـودُ

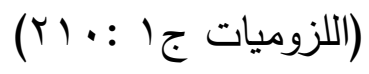

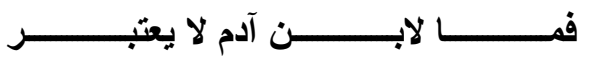

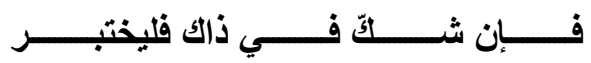

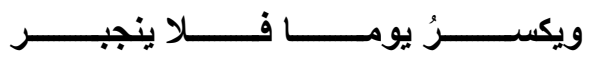

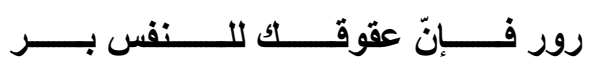

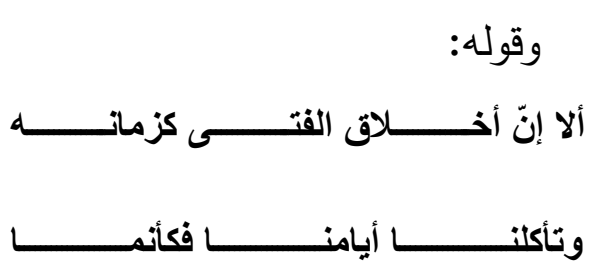

وقـــ يخمـل الإنســــن فـــ عنفوانـــه

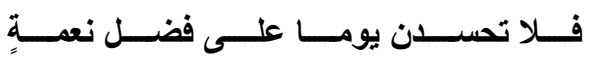

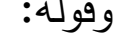

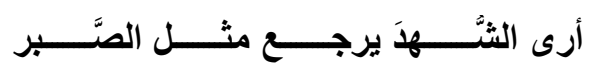

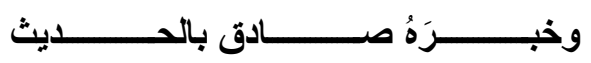

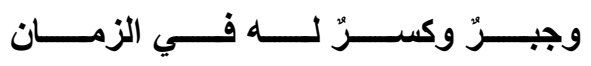

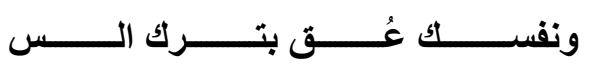

(§)।: اللزوميات ج)

من الملاحظ أن فكرة الزمان عند المعري تعود جذورها إلى مفهوم الزمان في

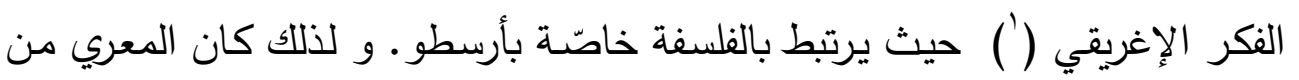

ا عرِّف الزمان علميًا على أنه نوعين هها: زمان فيزيائي، وزمان نفسي. الزمان الفيزيائي وهو

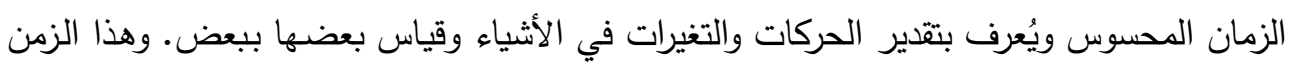

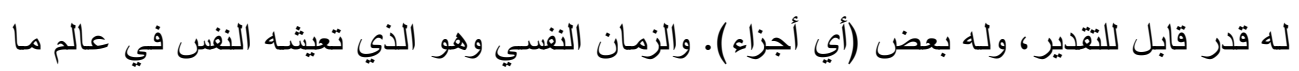

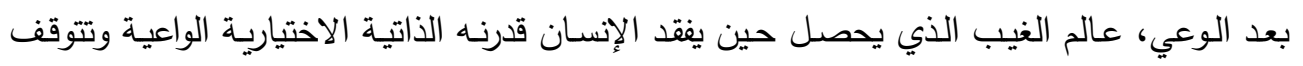

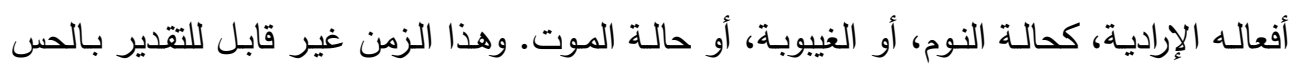

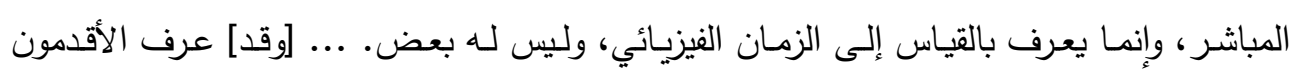

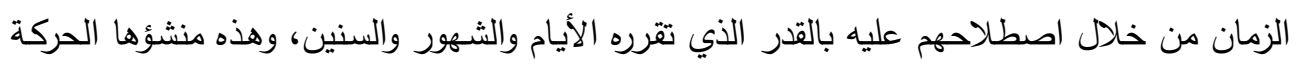


الثعراء الذين تأثروا بهذه الفلسفة ـ مفهوم الزمان عند أرسطو له جانبان: موضوعي:

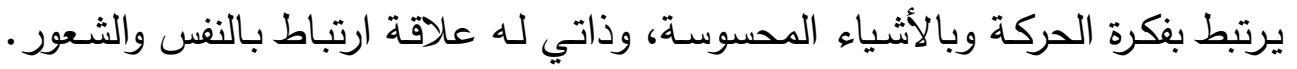

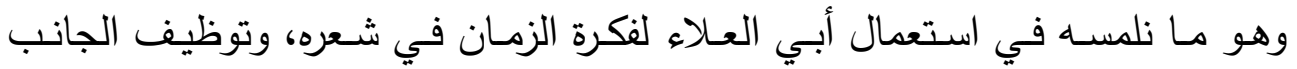

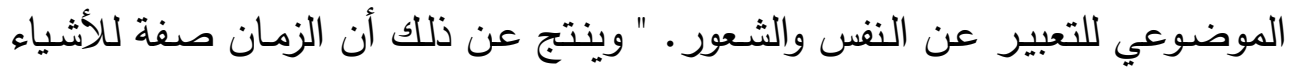

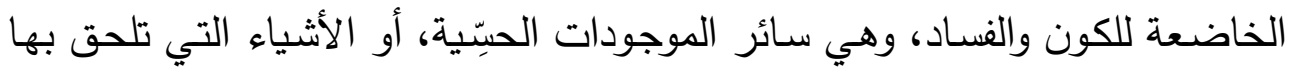

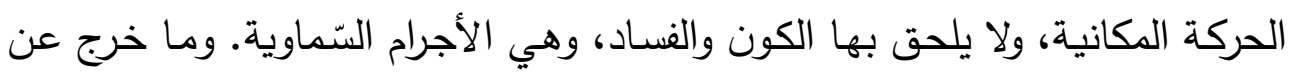

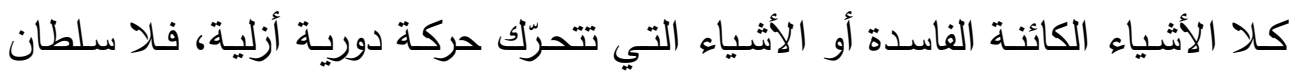
للزمان عليه. وكأن الزمان يجري وحسب على ما هو محسوس، وتلك مسالة هامّة في

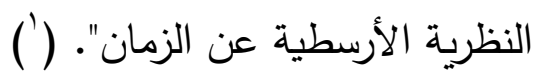

الفلكية والكونية، والتغير الملحوظ في الأحوال، كتعاقب الليل والنهار ، وحركة الثمس والقمر ." أنظر

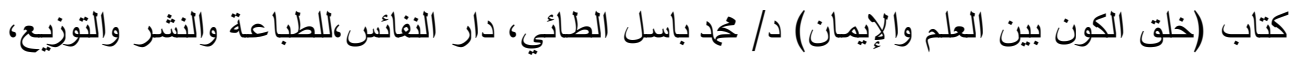

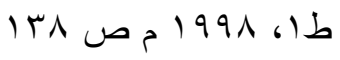

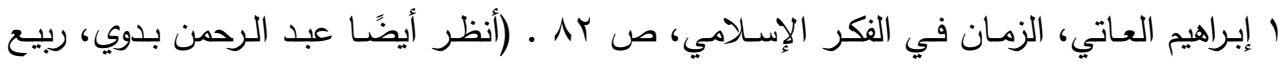

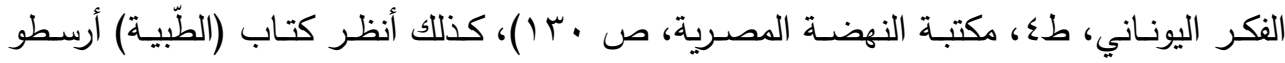

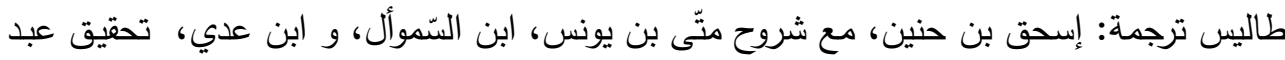

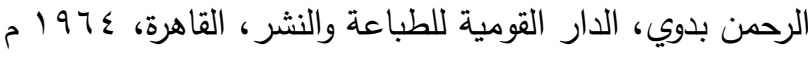




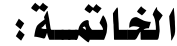

نحن إذن أمسام ظاهرة فريدة في إنتاج الفكر المعرفي، جعلت من الثعر جسرا

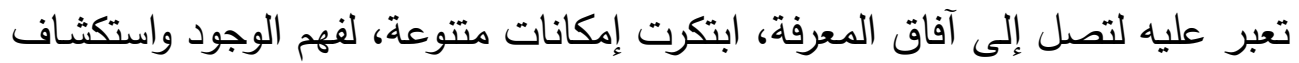

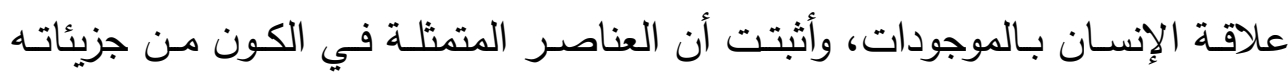

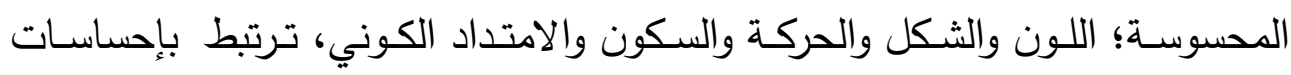

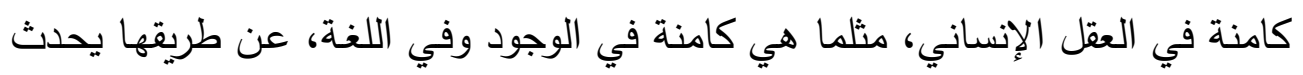
الفهم الإنساني.

و العقل يدرك جوهر الأشياء وليس ظاهرها فحسب، و اللغة تلعب دورا وسيطًا في

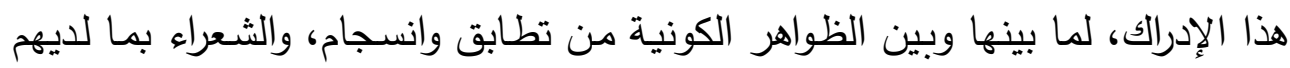
من حس فني و ملكة لغوية، و فهم للوجود والموجودات في حركتها وسكونها، يدركون

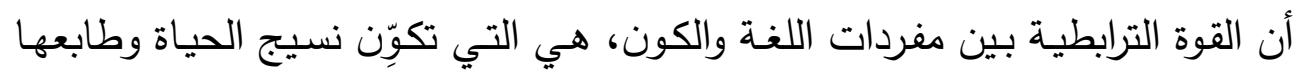

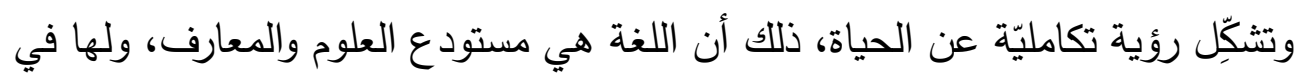

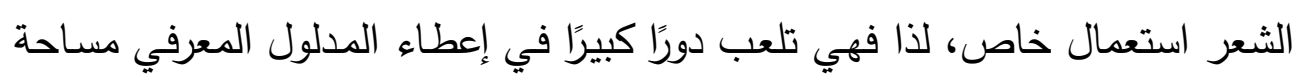
واسـعة في صـناعة الثـعر وفههـه، وإن كانـت في ظـاهرهـا لغــة الكنايـة والمجـاز

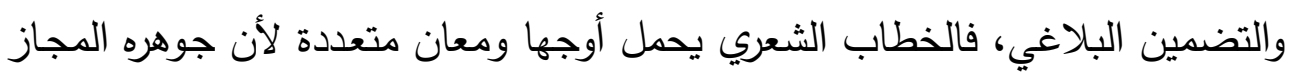
والاستعارة والكناية، وقراءة الشعر يجب أن ترتكز على هذه المساحة من التعددية.

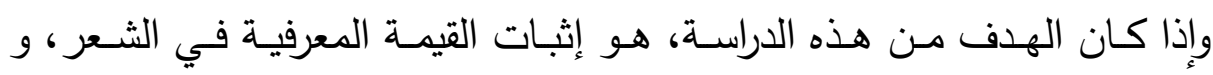

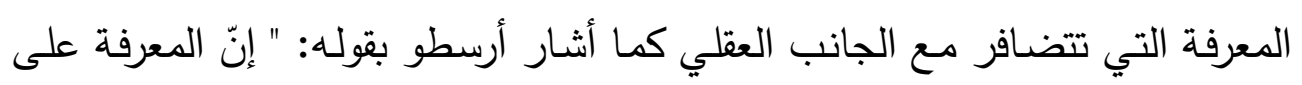

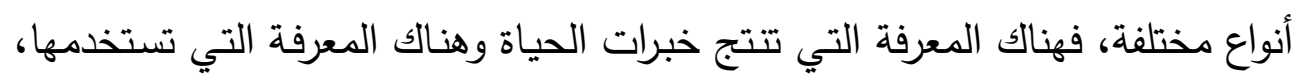

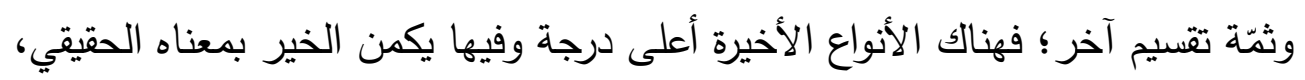

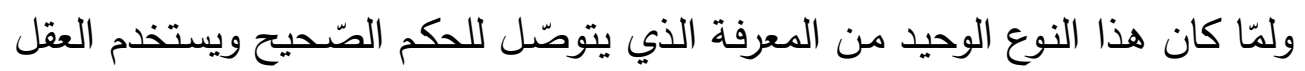

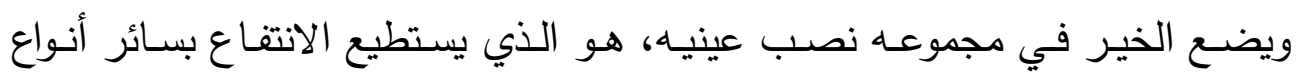

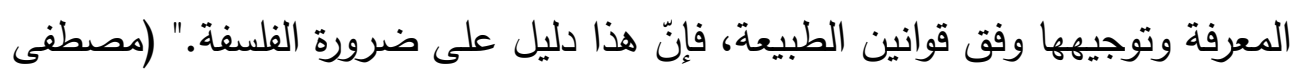




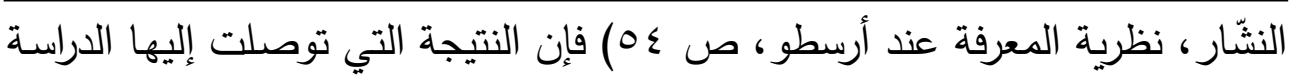

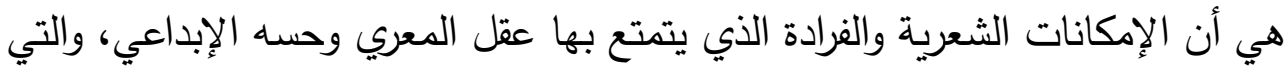
مكنته من دمج المفهوم المعرفي في الإيقاع الشعري، مع احتفاظه بالقيمة الفنية في

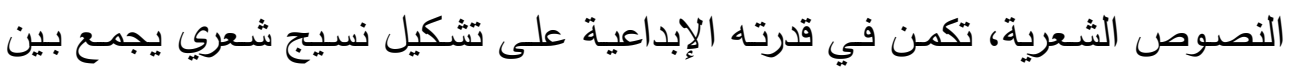
العقل و الخيال، في دمج المعرفة بالشعر، حتّى جعل من الشعر مصدرا زاخرّا بمعرفة الإبة

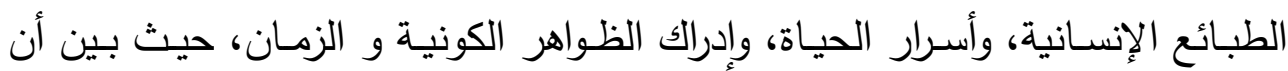

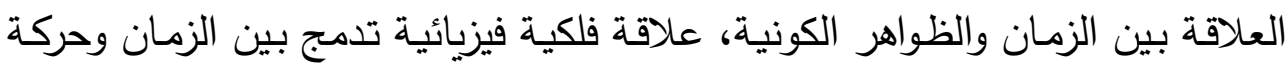

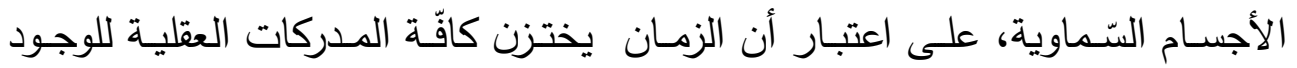
والموجودات في المراحل الحياتية للإنسان.

إضافة إلى ذلك فهو عندما يحيل الظواهر الكونية بما فيها الزمان إلى رموز لها

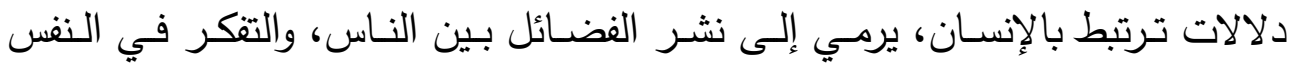

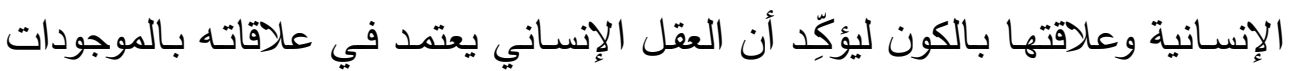

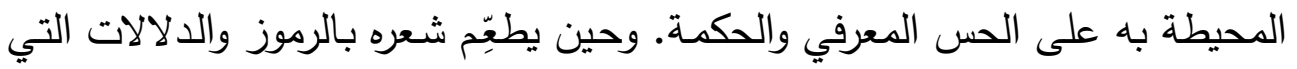

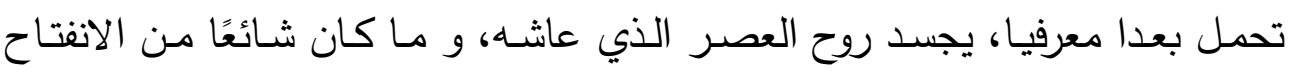
الثقافي والمعرفي في كل أوجهه الفكرية والاجتماعية، من خلال الاتصال بحضارات الإغريق والفرس والهند التي امتزجت بالقيم الإسلامية والعربية، وهو بذللك يؤكد فكرة

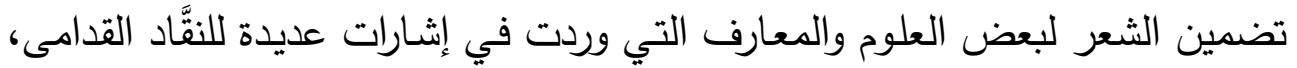

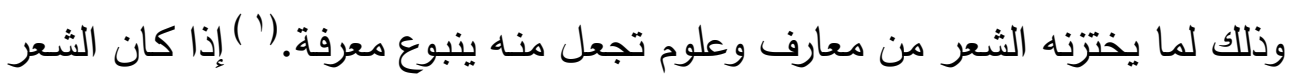
بهذه السمة، فقد يمنحنا ذلك مبررا في تتاولنا البعد المعرفي في شعرد معرد المعري.

ا ما ورد من آراء للنقاد يشير إلى حقيقة وجود هذه الأبعاد المعرفية في الأدب عامّة والثعر العربي

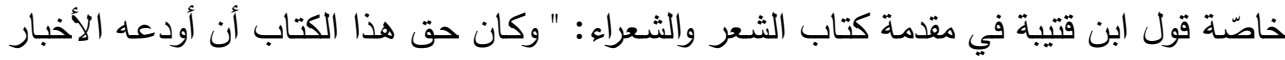

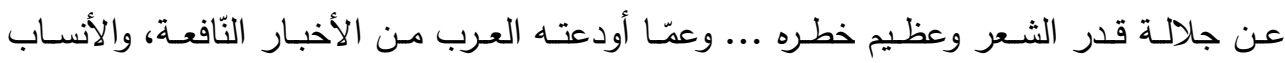

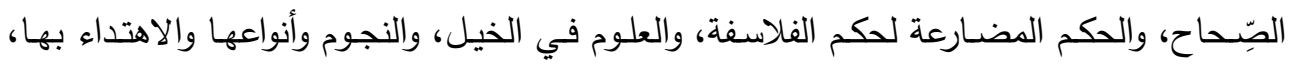

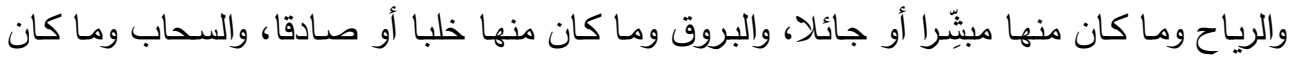


هذا هو أبو العلاء المعري، الثّاعر الذي أمسك بطرف حبل المعرفة متنقلا بفكره

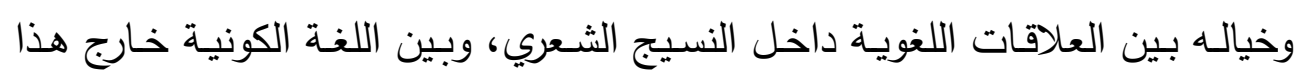

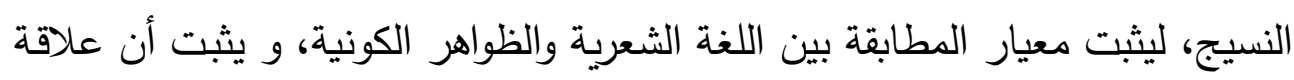
الوجود بالإنسان تكمن في العقل الفعّال وأن الفكر يدرك الوجود بحاسة السمع والفئ والخيال

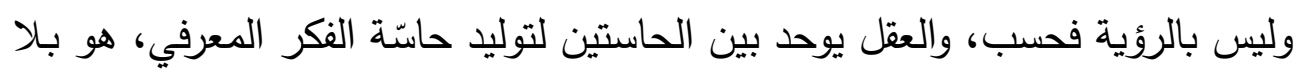
جدال جدير أن ينال لقب شاعر الفكر و المعرفة .

\section{المراجــــ}

ا ـ إبراهيم العاني، الزمان في الفكر الإسلامي، (ابن سينا - الرازي - المعري ) دار

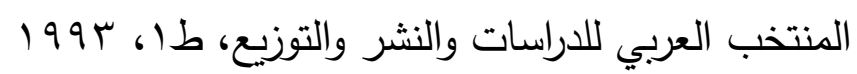

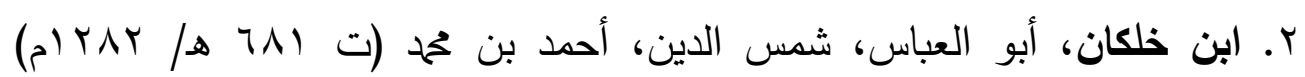

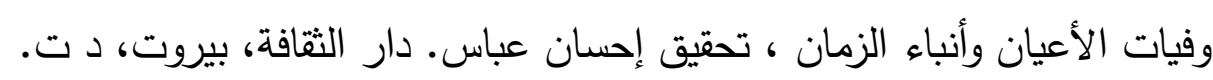

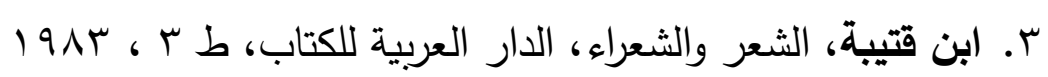

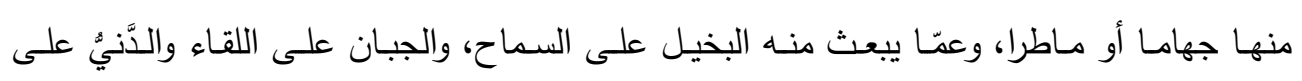

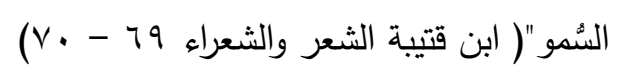

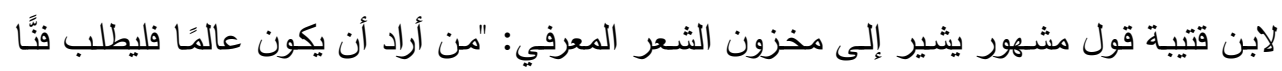

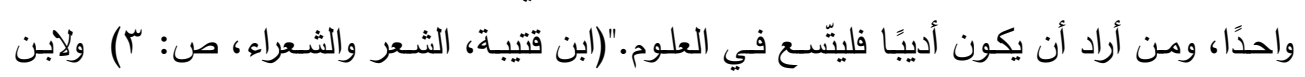

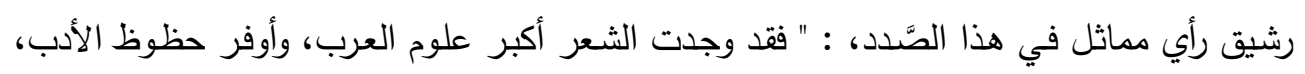

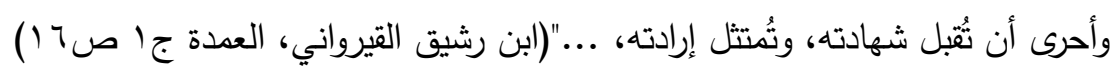




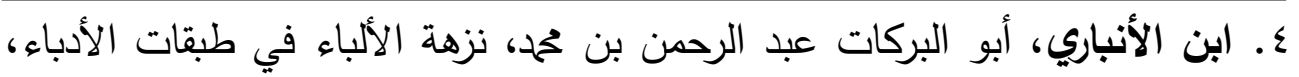

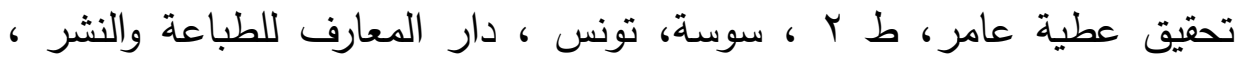

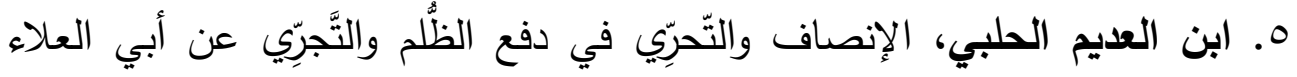

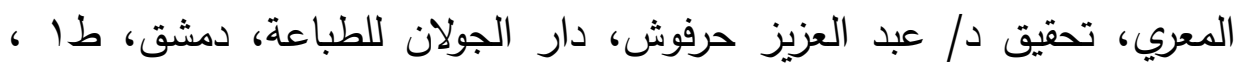

$$
\text { r r... }
$$

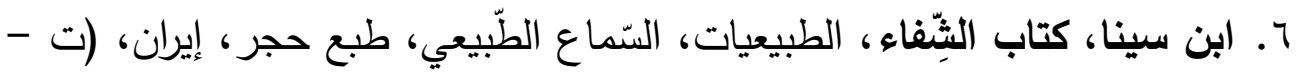

بدون)

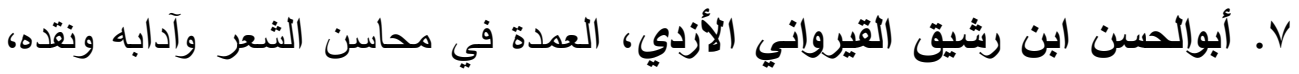

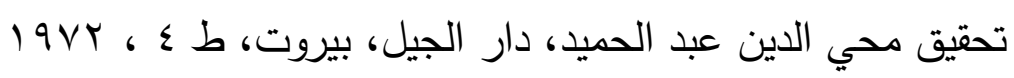

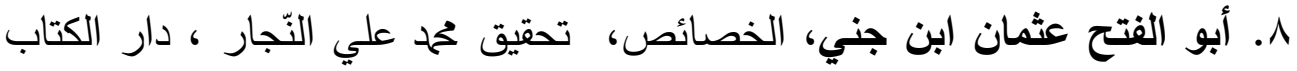

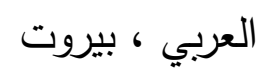

9. أرسطو طاليس، ألأخلاق، ترجمه إسحاق بن حنين، حققه وشرحه وقدّم له عبد

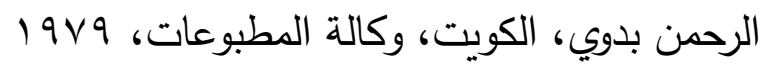

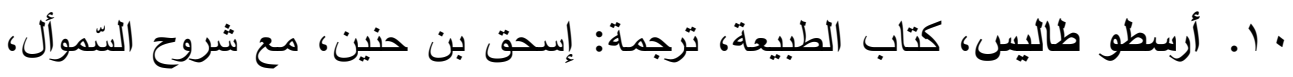

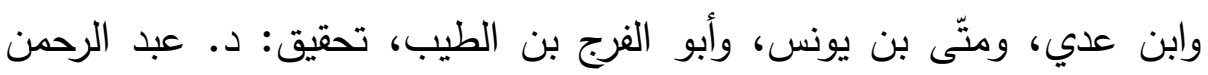

بدوي، الدار القومية للطباعة والنشر ، القاهرة، ع 197

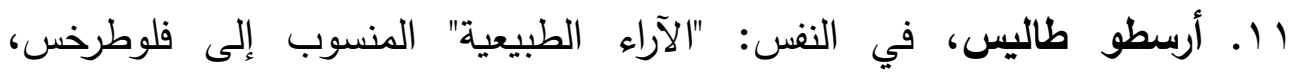
"الحساس والمحسوس" لابن رشد، "النبات " المنسوب إلى أرسطو طاليس،

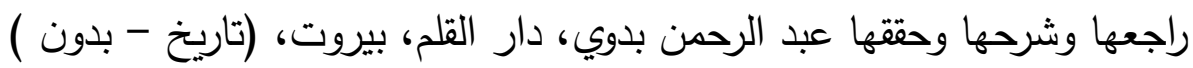

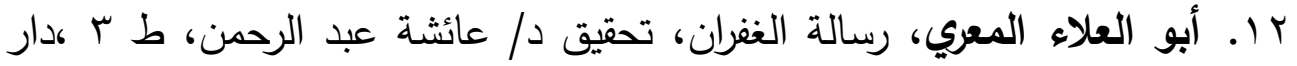

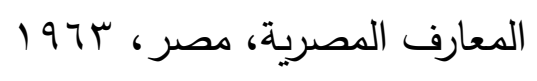

با ا. الثّالبي، يتيمة الدهر في محاسن أهل العصر، دار الكتب العلمية، بيروت، طا

$$
\text { 519V9، }
$$


ع ا. الجاحظ ، الحيوان ، تحقيق عبد السلام هارون، بيروت ، ط ب ، 1979 1 ا ـ القفطي ، تعريف القدماء بأبي العلاء، دار الكتب، دصر ، 7 ا. القرطاجني، أبو الحسن حازم منهاج البلغاء وسراج الأدباء، تحقيق تحمد الحبيب

$$
\text { ابن خوجة، بيروت ، دار الغرب الإسلامي، } 1919
$$

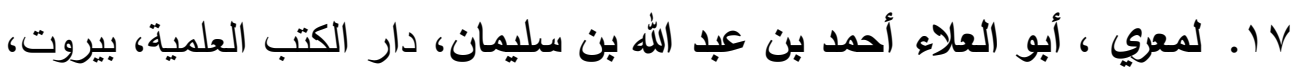

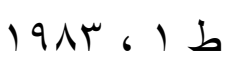

1 ا. بلانثي، روبير، نظرية المعرفة العلمية (الإبستمولوجيا)، ترجمة: د/ حسن عبد

الحميد، مطبوعات جامعة الكويت، الكويت، 1917

9 1. بول ريكو، الوجود والزمان والسرد: فلسفة بول ريكور، ترجمة سعيد الغانمي،

$$
\text { المركز الثقافي العربي، طان، } 1999
$$

•r. رسول، رسول عحم، مسألة الإبستمولوجيا بين النصين الفكري والمعجمي،

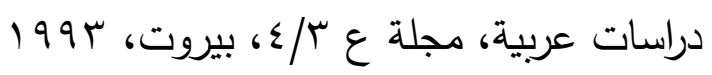

ا ا.. رسول محمد رسول، المعرفة النقدية: مدخل إلى نظرية المعرفة في الفلسفة، دار

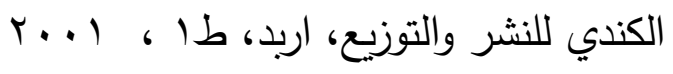

r.r. شوقي ضيف، الفن ومذاهبه في الشعر العربي، دار المعارف، مصر ، طV. سr. طه حسين، من تاريخ الأدب العربي (العصر الجاهلي والعصر الإسلامي)، دار

$$
\text { العلم للملايين، بيروت، طه ، } 1991
$$

ع r. . طه حسين، تجديد ذكرى أبي العلاء، مطبعة الواعظ، مصر ، ط7 ، س7 19

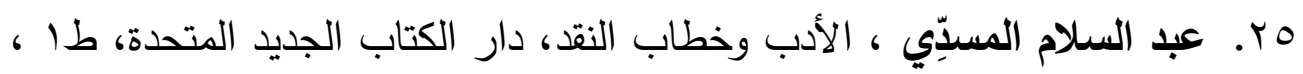
r...

דr. . عبد الرحمن بدوي، ربيع الفكر اليوناني، مكتبة النهضة المصرية، ط ع V V. عز الاين إسماعيل ، الشعر العربي المعاصر؛ قضاياه وظواهره الفنية

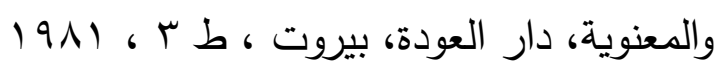


^^. r علي سامي النشار، نشأة الفكر الفلسفي عند اليونان، منشأة المعارف،

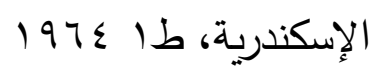

و r. علي سامي النّشّار، مناهج البحث عند مفكري الإسلام، دار المعارف، مصر ،

$$
\text { ط ط ، } 1977
$$

• ץ. كوين جون ، النظرية الشعرية: بناء لغة الشعر، اللغة العليا، ترجمة أحمد درويش، القاهرة، دار غريب

اس. ليينتز، جوتفريد، أبحاث جديدة في الفهم الإنساني، ترجمة أحمد فؤاد كامل، دار

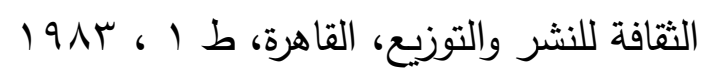

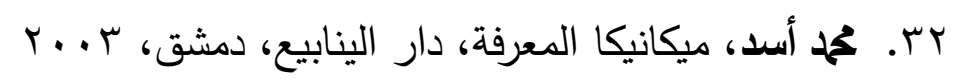

سب. مفتاح، مححد، مشكاة المفاهيخ: النقد المعرفي والمثاقفة، الدار البيضاء، المركز

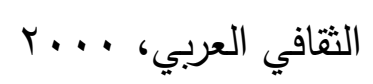

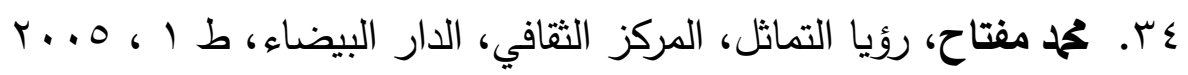
ه广. محمّد سليم الجندي، الجامع في أخبار أبي العلاء وآثاره، تحقيق عبد الهادي

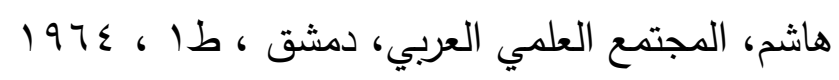

$$
\text { דr. عحم عنبر، الشيء في ذاته ، دار القلم ، دمشق ، } 199
$$

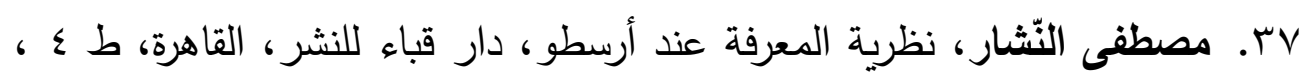

$$
r \cdot 1
$$

^ץ. عحم باسل الطّائي، خلق الكون بين العلم والإيمان، دار النفائس للطباعة والنشر

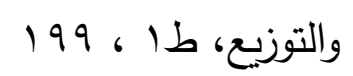

q

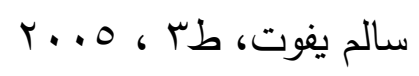

• ع. ميشال فوكو، الكلمات والأشياء، ترجمة مطاع صفدي، مركز الإنماء القومي،

$$
\text { بيروت، طا، ، 199 }
$$




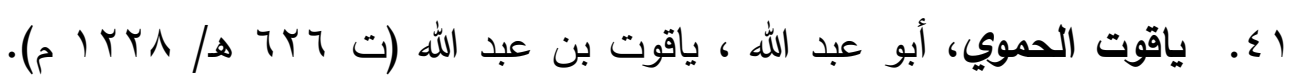

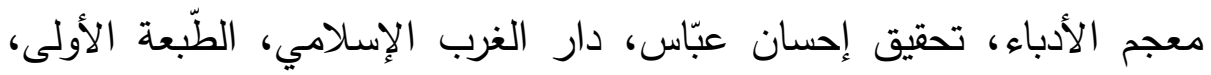

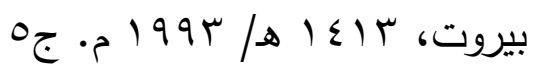

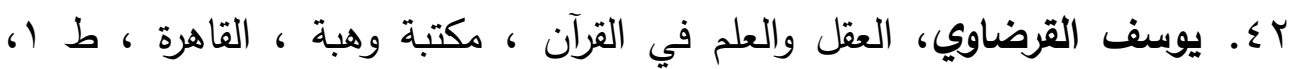
1997

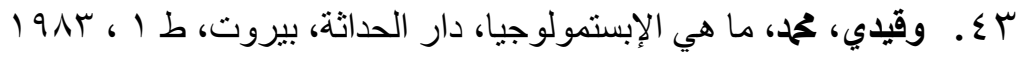




\section{English sources}

- Aristotle. "Poetics". Translated by Georg Whalley (1997). Edited b y John Baxter and Patrrick Atherton. London.MeGill- Qeen's University Press.

- Rader, M, and Jessuf, B , Art and Human Values, Prentice-Hall. N.Y - 1967 .

- Acomprehensire Etymological Dictionary Of the English Language, Ernest Klein. Vol. 11 cnew York: Elsevier publishing (1967)

- F, E Peters, Aristotle and the Arabs: The Aristotle - lian Tradition in Islam, (New York university press, 1968.

- Sikes, E. E, The Greek view Of Poetry. London: Methuen, 1931.

- Aesthetics and Philosophy of Art Criticism: A Critical Introduction, Jerome Stolnitz, Houghton Mifflin Company. Boston, 1960. 


\section{المستخلص}

تهدف هذه الدراسة إلى إثبات القيمة المعرفية في اشعر أبي العلاء المعري دون المساس بخاصية الشعر أو بالقيمة الفنية في النصوص الشعرية، حيث أبدع نسيجا شعريا يجمع بين العقل و الخيال، حتّى جعل من الشعر مصدرا زاخرّا بمعرفة الطبائع الإنسانية، والطبيعة الحياتية، إضـافة إلى ربط الظواهر الكونية بالزمان الذي يختزن كافّة المدركات العقلية للوجود والموجودات. والمعري في هذه الإحسالات يرمسي إلى لـى التفكر في النفس الإنسانية وعلاقتها بالكون، مؤكِدا أن العقل الإنساني يعتمد في فهمه للموجودات المحيطة به على الحس والإدراك العقلي والبصيرة.

وهو حين يطعِّم شعره بالرموز والدلالات التي تحمل بعدا معرفيا، يجسد روح العصر الذي عاشه، و ما كان شائعًا من الانفتاح الثقافي والمعرفي في أوجهه الفكريـة والاجتماعية، من خـلال الاتصـال بحضـارات الإغريق والفرس والهند، ومزجها بالقيم الإسلامية والعربية، كما يرمي إلى نشر الفضائل بين الناس، وترك الرذائل، لما لمسه أثناء اندماجه في مجتمع المدن من فساد في التعامل والعلاقات التي لا تتناسب مع إنسانية الإنسان.

وقد ربط المعري بين العلاقة اللغوية داخل النسيج الشعري، وبين اللغة الكونية خارج هذا النسيج، ليؤكد معيار المطابقة بين اللغة الشعرية والظواهر الكونية، و يثبت أن علاقة الإنسـان بـالوجود تكمن في العقل الفعّال وأن الفكر يدرك الوجود بحاسـة السمع والخيال وليس بحاسّة الرؤية فحسب، والعقل يوحد بين الحاستين لتوليد حاسّة الفكر المعرفي. واللغة تلعب دورا وسيطًا في هذا الإدراك.

وفي لزوميـات المعـري نجد أن اللغـة الثـعرية، وإن كانـت في طبيعتهـا تتسـم بالمجاز والتضمين البلاغي، فهي تحمل في مضمونها أوجها متعددة من المعارف، 
مؤكدا أن القوة الترابطية بين مفردات اللغة وبين الكون هي التي تثكّل رؤية تكاملية عن الفكر الإنساني وفهمه للوجود. فلعل فنلك لتتاولنا البعد المعرفي في شعر المعري ما له مبرر أبو العلاء المعري ظاهرة تمثل طرفا رئيسيا في إنتاج الفكر المعرفي، حيث

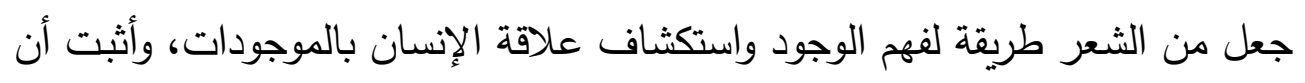

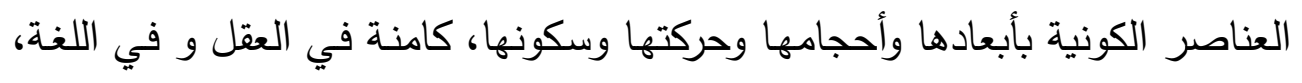
مثلما هي كامنة في الوجود، تلتقطها الحواس و يدرك العقل جوهرها وليس ظاهرها فحسب،

هذا هو المعري، شاعر الفكر و المعرفة ، شاعر في منظومة الشعراء، و مفكر

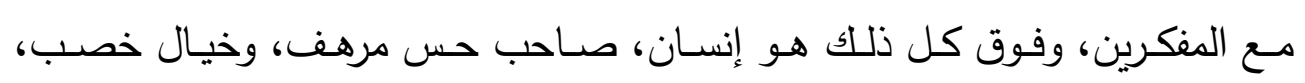

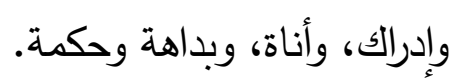




\begin{abstract}
$\underline{\text { Abstract }}$
This study aims to treat and determin the value of knowledge in poetry, recording Abu alaa almearry as an example for this subject. The reason that we consider almeary as an example is based on his ability to join poetry and the idea of epistemology without causing any damming in the text of poetry, he also was able to link between thought and imagination to produce the image of epistemological poetry.
\end{abstract}

In such fact one can approach in his reading the nature of humane, the phenomena of life, the silent and sound of the Universe, , time and place that contain things and events the idea of connected meaning in man's life and the universe . In all these aspects, Almarry refers to the inner of the Man, thought, and self, in terms of its link, relation and understanding the universe, based on his sense and ability to comprehend objects of life.

When Almeary symbolized his thought in various aspects of the epistemology and different cultures, He refers to Abbasid period which is considered to be called the golden age of Arab history. For it was an Opining land and period to deferent cultures such as Persia, Roman, and India from which the Arabs acquired various kinds of knowledge, and from Europe they also adapted some of their cultures and sciences, from which he himself embrace most of his achievements of knowledge.

When he Write about the relation of language inside the text and the relation of objects in universe, he proves that they are applicable in various aspects, and the active and witted mind is the one who can comprehend the relation between the two languages and grasp the concept of their correspondence, Therefore, it is highly important to think deeply in the question of what is the aspect of the nature of the universe that link with and the nature of Man?.

In his collection Allozomyyat, Almeaarry pointed out that the link between Nature and Man lies in Language, for the language storage both man's experience in life and the universal phenomena and events. With all these aspects the poetical language presents a complete picture of human thought and relation with nature. And the poet is the one who is able to draw this valuable image In this regard, we consider the poet as a phenomena that invent different and clever ways to approach the meaning of life and discover the thread of knowledge to understand the construction of language and the universe and discover that the relation between them affirm that the all aspects of life lies in the universe as well as in the language and man's thought, and the poet is the one who pictures them in a valuable way of poetic language, and with no doubt, Almearry is consider to be the most capable poet of such task, 